\title{
النظام القانوني لتأجير الطائرات
}

\author{
دكتور \\ طاهر شوقي مؤمن \\ مدرس القانون التجاري بقسم القانون \\ كلية العلوم الإدارية والمالية \\ جامعة الملك خالد بالسعودية
}





\section{مقدمة}

[1] دعا المولى سبحانه وتعالى الإنسان للسير في الأرض، فقال تعـالى: "...

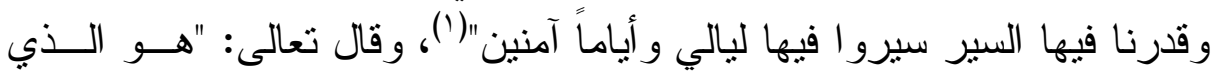

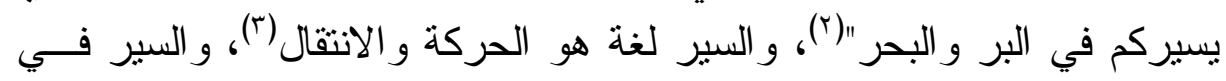

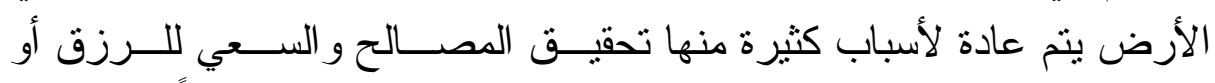

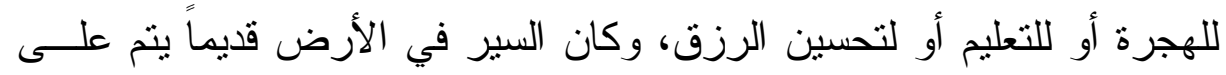

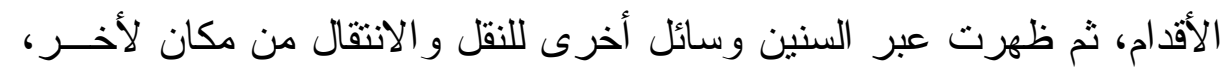

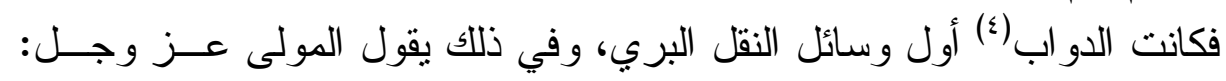

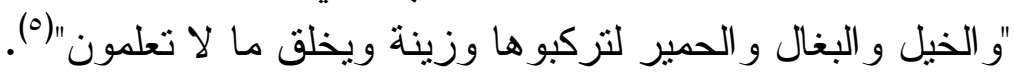

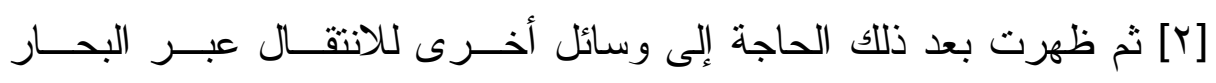

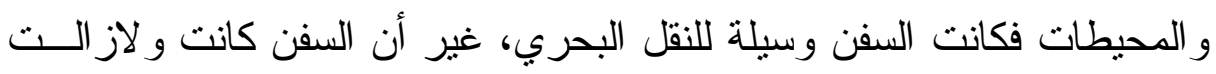

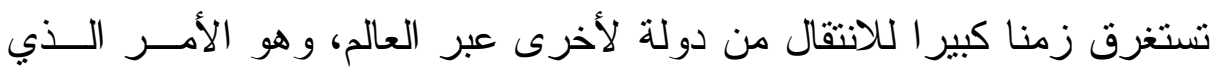

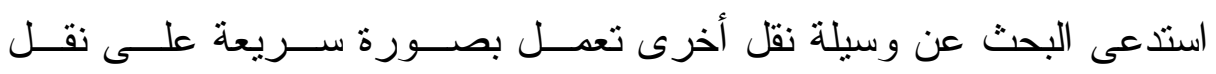
الأشخاص و البضائع و البريد، فظهرت المركبات الهو ائية aéronefs، و التئي

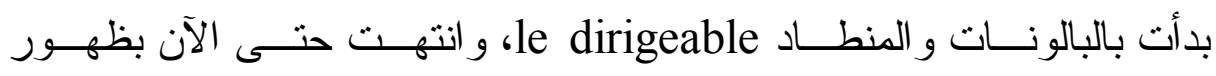

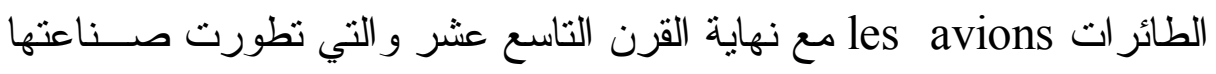

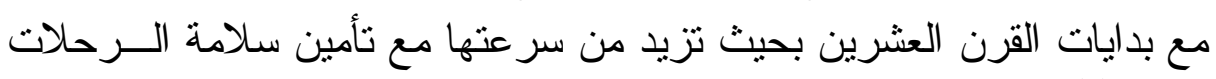

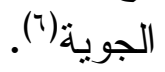

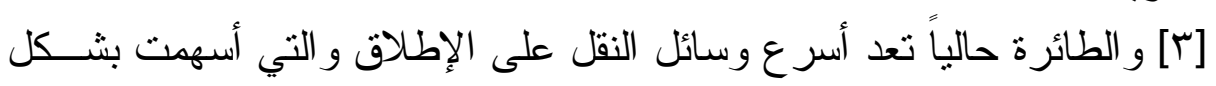

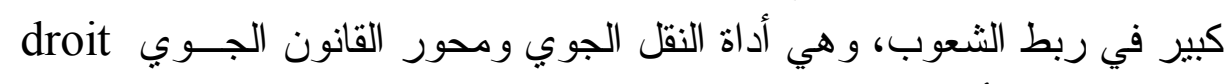
aérien

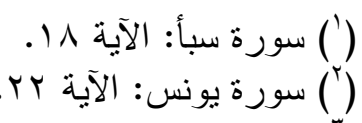

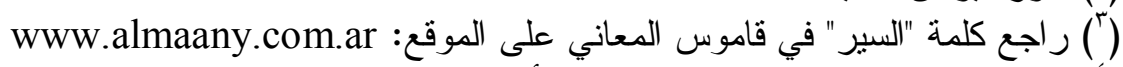

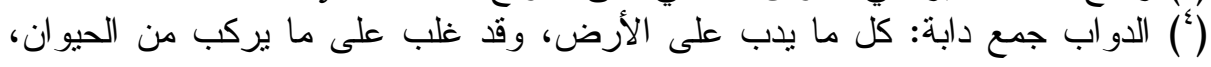

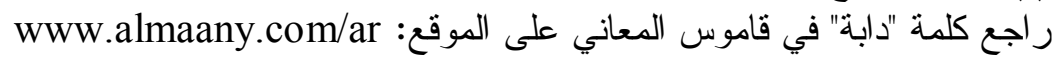

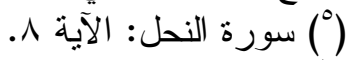

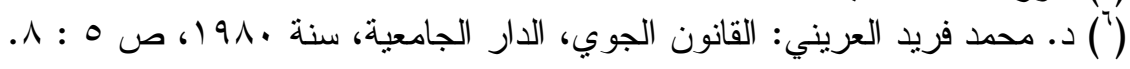




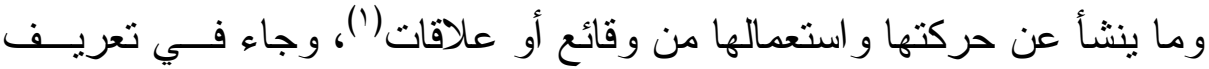

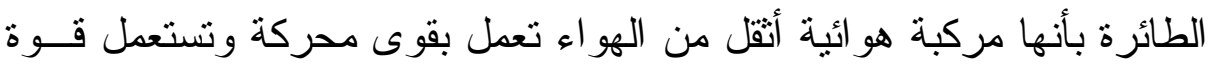
رفعها أساساً للطير ان من ردود فعل حركة الهو اء على أسطح تظل ثنابتة فـي فئي

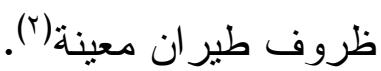

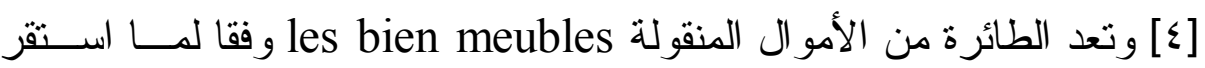

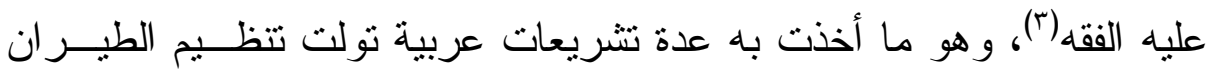

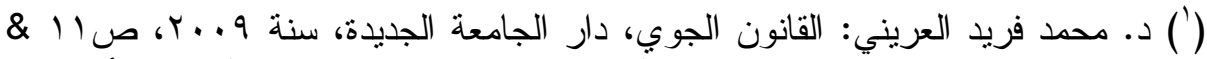

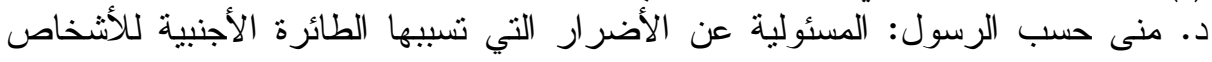

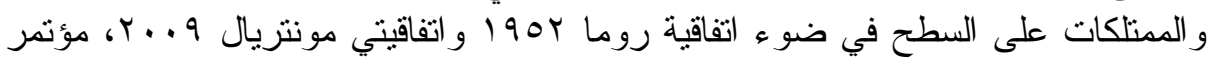

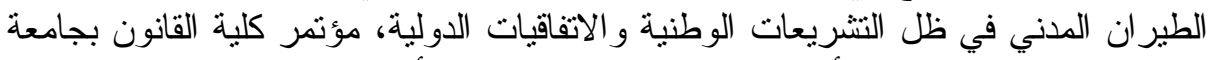

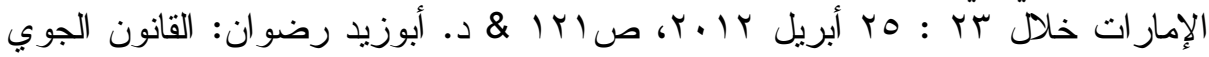

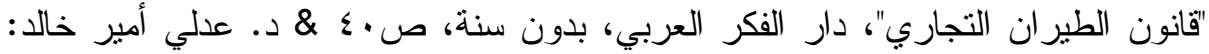

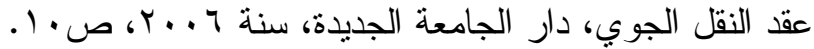

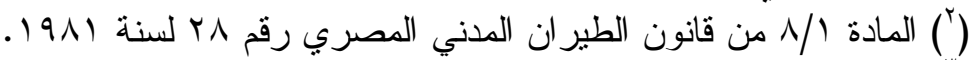

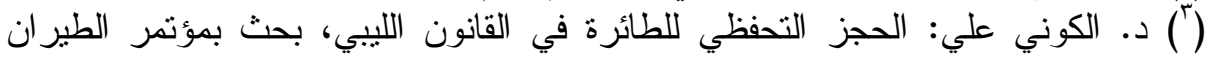

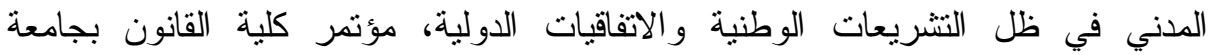

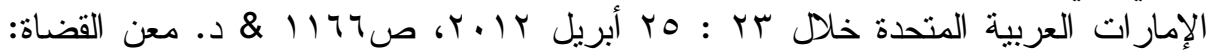

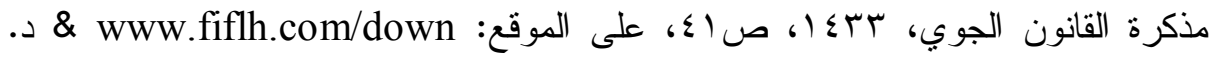

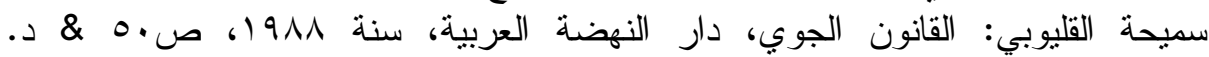

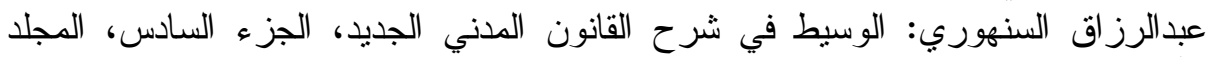

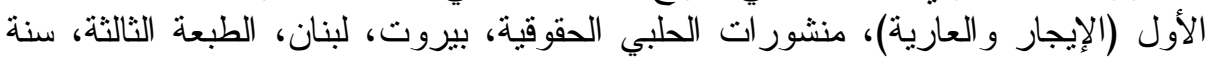

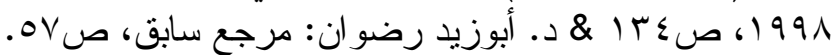
Wolfgang Faber, Brigitta Lurger, National Reports on the transfer of movables in Europe, Volume 4, seillier European law publishers, sur le site, http://books.google.com.sa/books?id, p. 14 \& Florent Vigny, Timothée Bertrand, propriété des aéronefs, Fasc 945, 3 Janvier 2007, Lexis Nexis SA - 2007, sur le site, www.rbm21.com/resources/article001, p. 2 \& Philippe Rodier, Recherche sur la fonction économique du droit de propriété dans le secteur du transport aérien. Thèse doctorat, de l' univesité de Toulouse, le 11 Octobre 2013, sur le site, www.theses.fr/2013tou10054.pdf, p. 53 et p. $59 \&$ Gabriel Seignalet, responsabilité du fait des choses, sur le site, www.conseil-droitcivil.com/article-droit-civil-1003 \& Maitre Anthony Bem, la possession de meubles vaut titre de propriete: conditions, effets et recours, la 26/06/2010, sur le site, www.legavox.fr/blog/maitre 


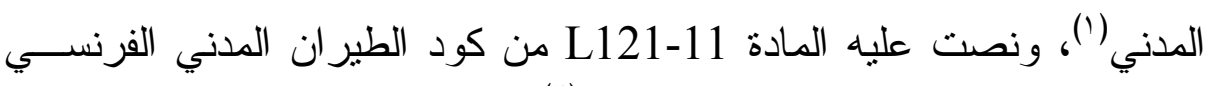

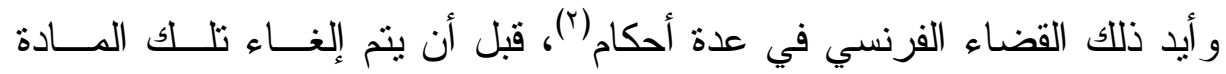

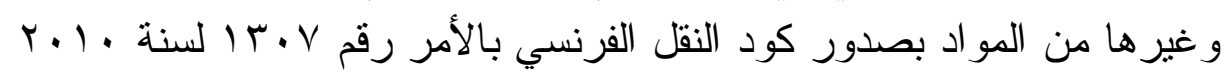

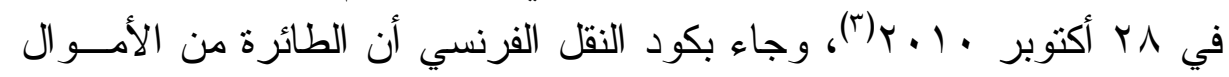

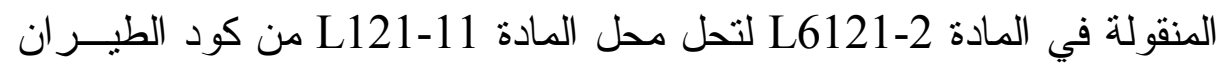
المدني، ولم يرد بالقانون المصري نص عن طبيعة الطائرة سو اء في القـانون

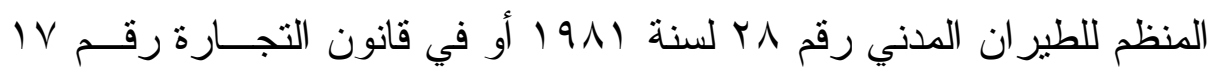

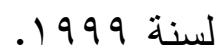

و الطائرة منل السفينة من المنقو لات ذات الطبيعة الخاصة ليس فقط من حيـــ

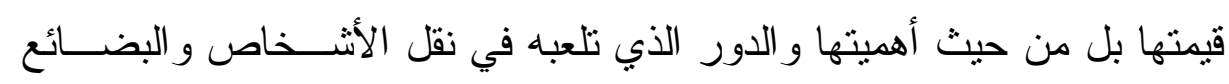

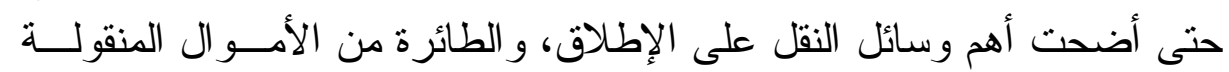

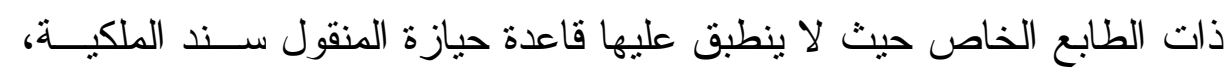

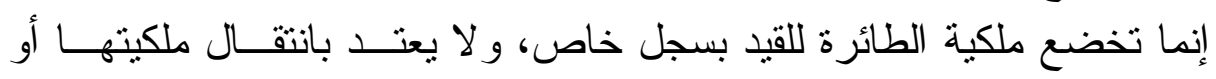

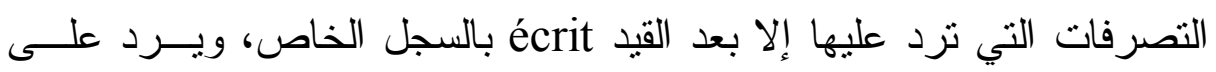

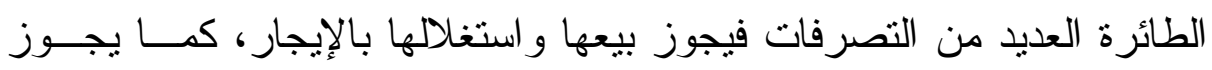

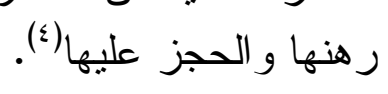

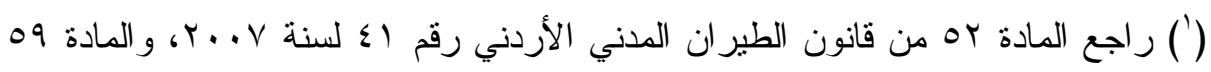

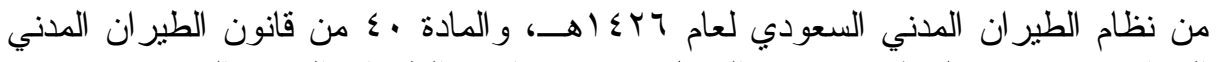

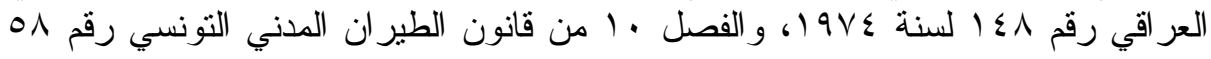

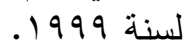

$\left({ }^{2}\right)$ CA de Grenoble, 15 Octobre 2008, N de RG: 1107-1909 \& C.A.A de Marseille, 9 Janvier 2007, N03 MA 02099 \& Cass.ASS, 2 Octobre 2015, N14-14256 \& Cass. Com, 9 Octobre 2012, N11-22023, les sentences sur le site, www.legifance.gouv.fr

$\left(^{3}\right)$ Ordonnance n2010/1307 du 28 Octobre 2010, sur le site www.legifrance.gouv.fr

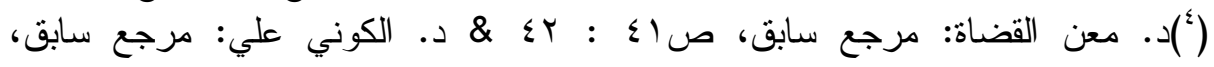

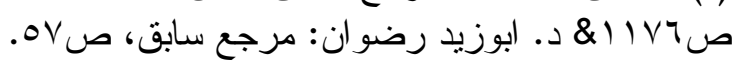

Maitre Anthony Bem, op. cit., \& Florent Vigny, Timothée Bertrand, op. cit., p. 17:20 \& Philippe Rodier, op. cit., p. 84 et p. 141.

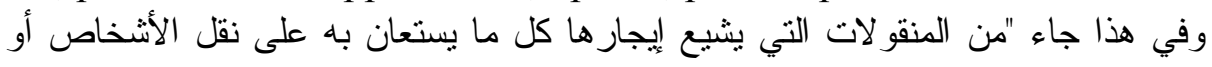

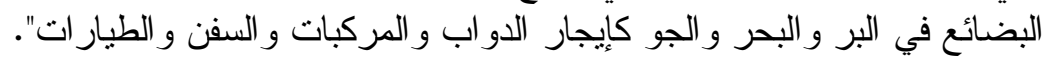


[0] و هذه التصرفات الواردة على الطائرة تم تتظيمها في العديد من التشريعات

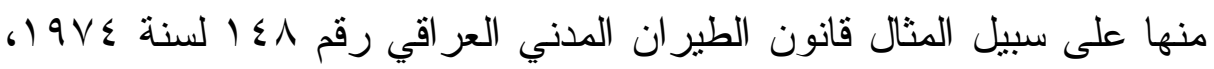
وقانون الطير ان المدني التونسي رقم

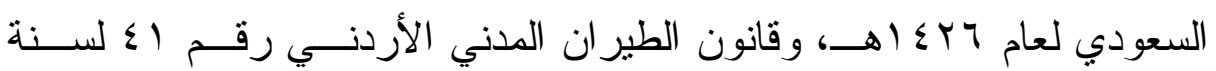

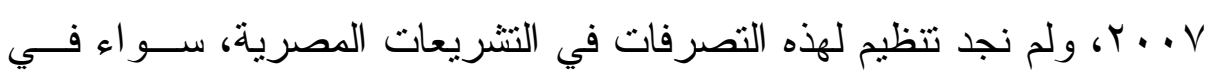

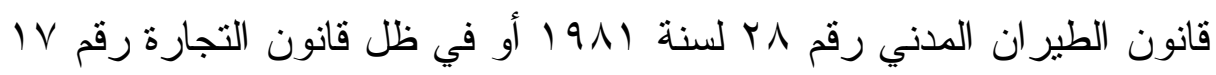

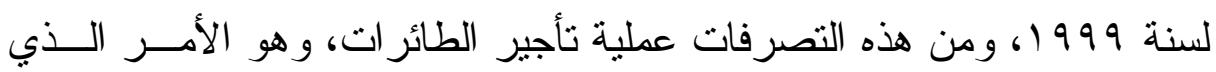
نأمل معهه من المشرع المصري العمل على تنظيم هذه التصرف التصرفات.

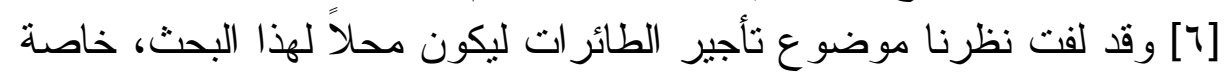

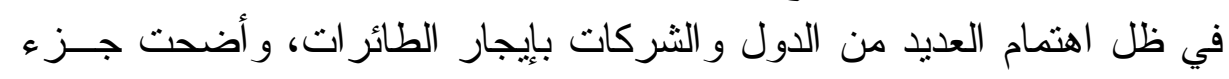

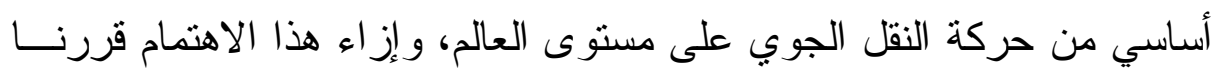

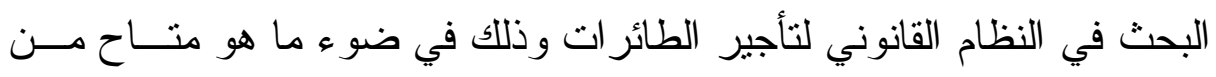

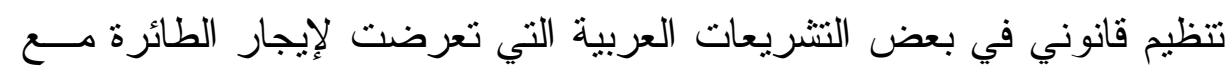

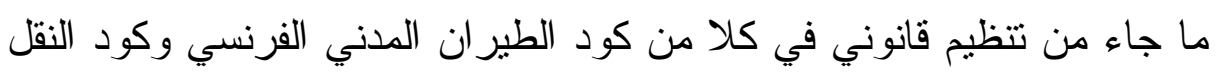

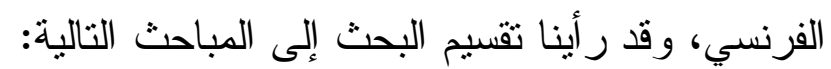

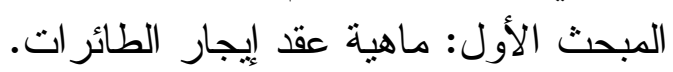
المبحث الثاني: آثار عقد إيجار الطائر ات. المبحث الثالث: المسئولية عن أضر ار الطائر ات المستأجرة.

راجع د. عبدالرزاق احمد السنهوري: مرجع سابق، صع؟با. 
العدد الأول- الجزء الأول - السنة الثامنة والخمسون- يناير 19. r =

\section{المبحث الأول \\ ماهية عقد إيجار الطائر ات الاول}

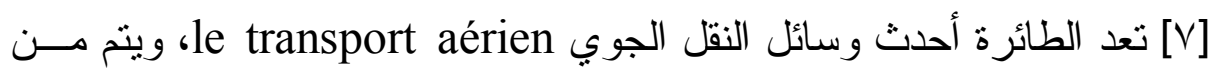

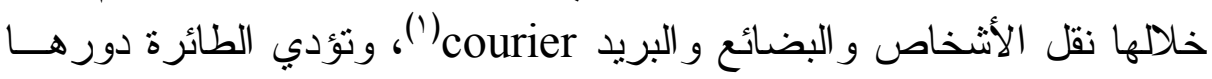
في النقل بغض النظر عن مشغل الطائرة سو اء أكان مالكها أو مستغلها، ويــتم

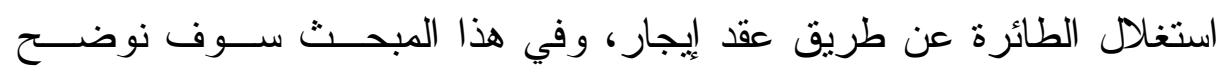

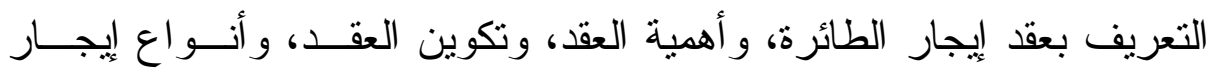
الطائر ات، وذللك في الفروع الأربعة التالية. الفرع الأول

التعريف بعقد إيجار الطائرات

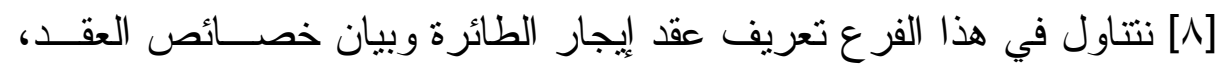

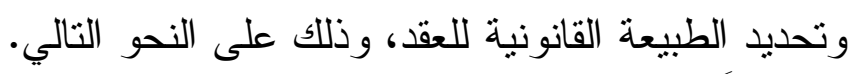
[9] أولاً: تعريف عقد إيجار الطائر ات:

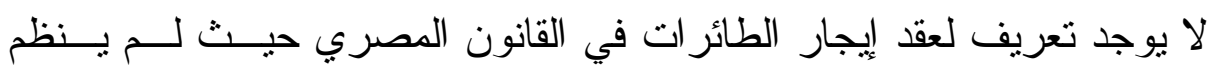

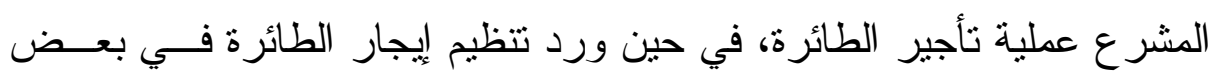

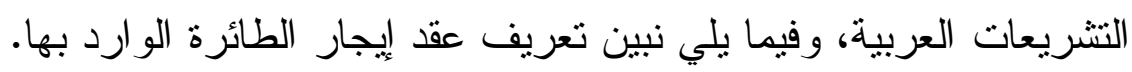

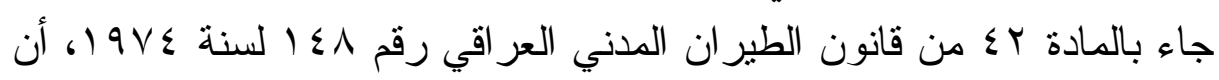

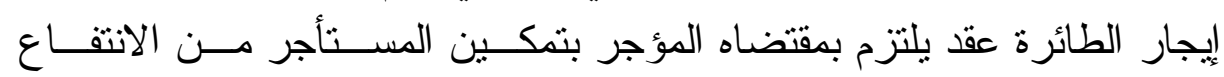

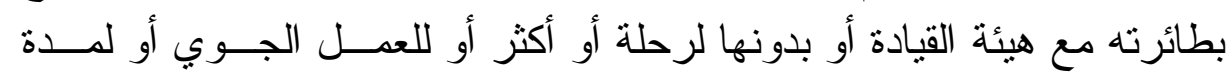
معينة، ذللك مقابل أجر أو مكافأة.

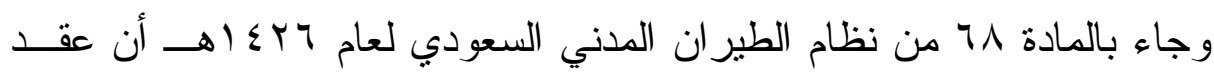

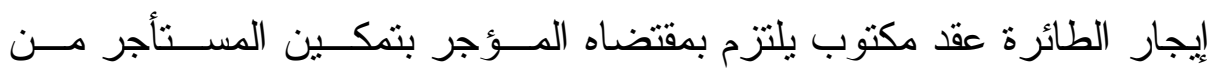

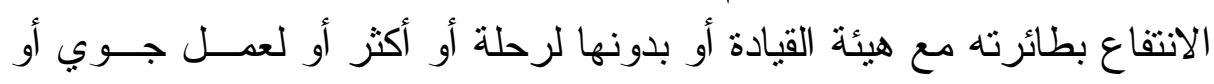

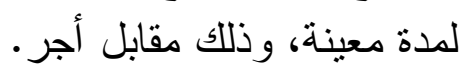

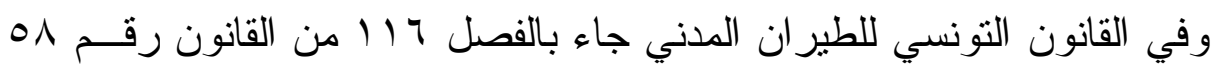

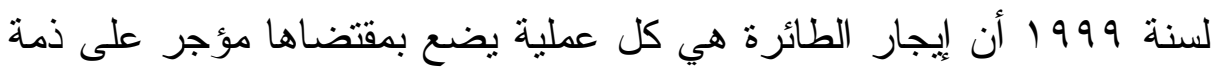

( $\left.{ }^{1}\right)$ Art. L6400-1 du code des transports. 
مستأجر طائرة مع طاقمها وييقى الطاقم تحت إدارة المؤجر ما لم يتم الاتفــاق على خلاف ذلك.

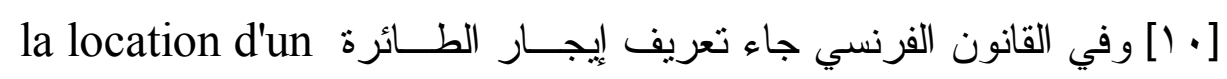

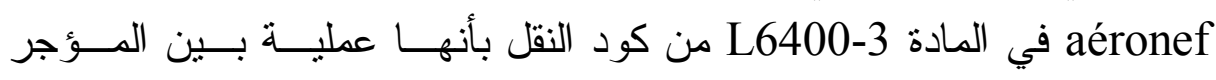
بأن يضع تحت تصرف أخر طائرة بدون طاقم bailleur

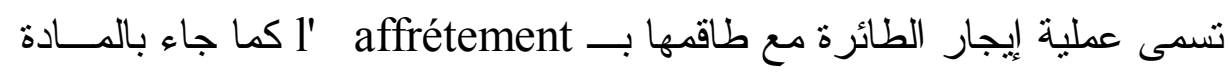

$$
\text { L6400-2 من كود النقل الفرنسي. }
$$

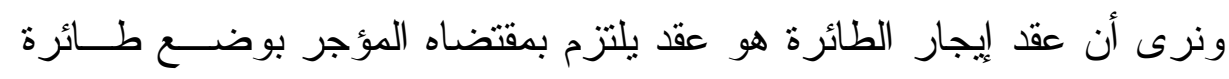
تحت تصرف المستأجر للانتفاع بها لفترة يحددها الاتفاق نظير أجر معين. [ [1 [1 [نانياً: خصائص عقد إيجار الطائر ات:

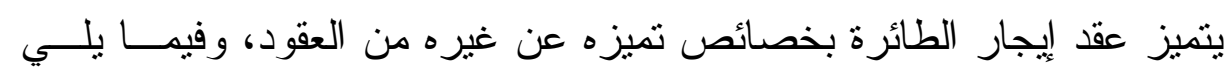
نبين ذلك:

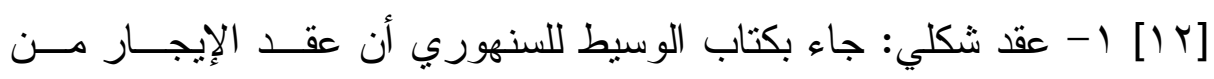

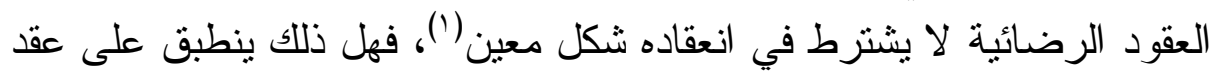

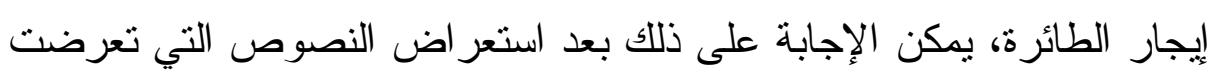
لإيجار الطائرة.

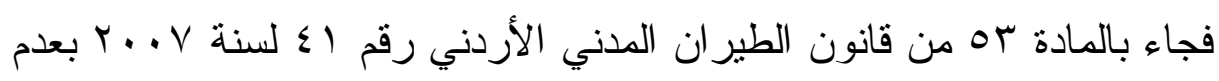

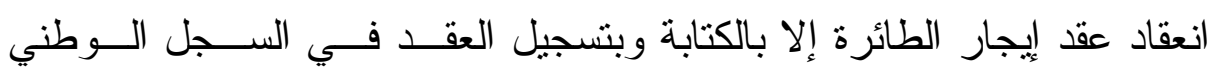
وبمو اققة الهيئة.

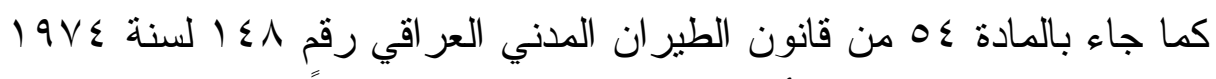

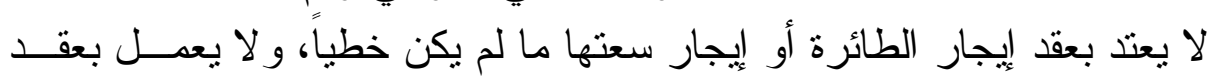

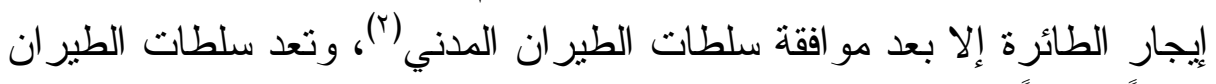

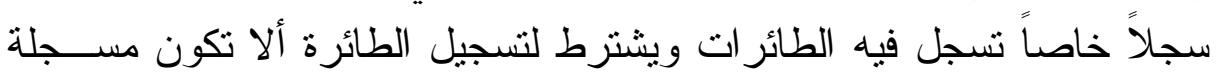

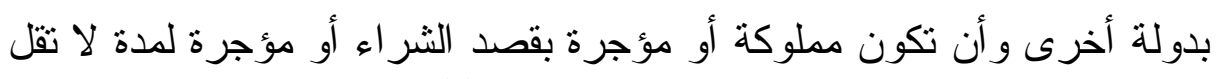

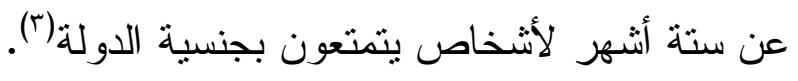

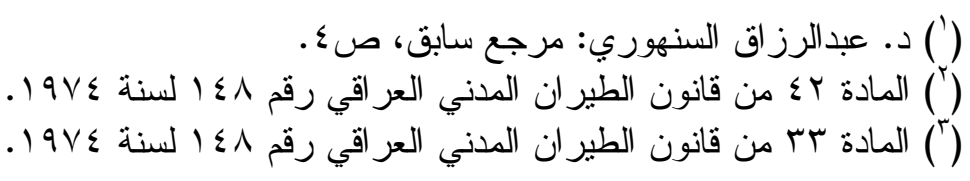




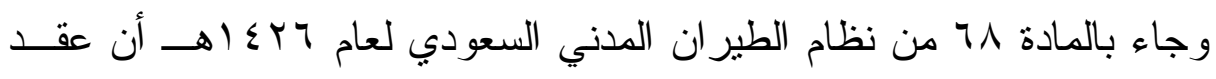
إيجار الطائرة عقد مكتوب ..... و لا يعمل بعقد الإيجار للطائرة إلا بعد مو افقة الايئة.

وفي القانون الفرنسي جاء بالمادة 46131-4 من كود النقل أن إيجار الطــائرة

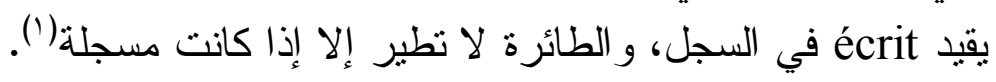

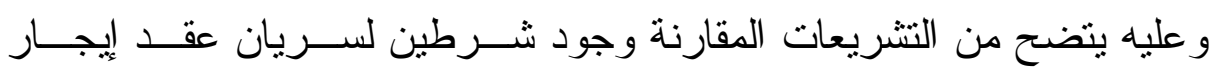
الطائرة، و وهما:

1 - الكتابة و لا يعتد بالعقد تجاه الغير إلا إذا كان مكتوباً.

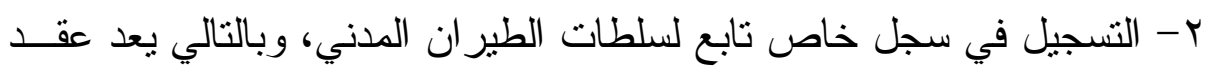

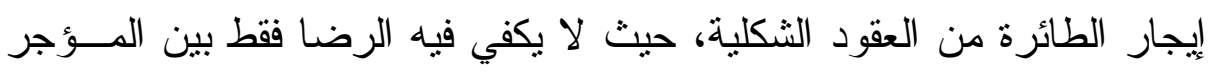

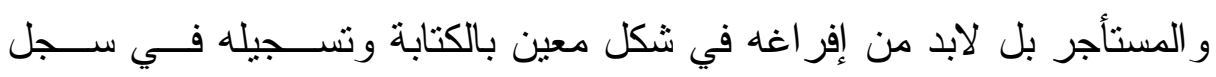

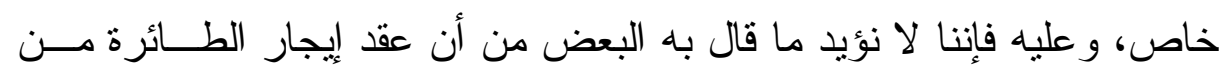

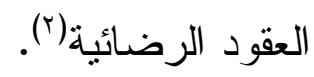

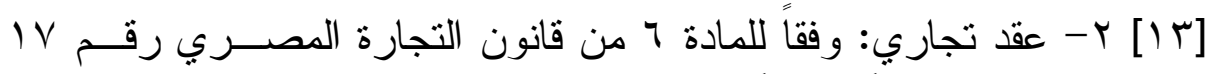

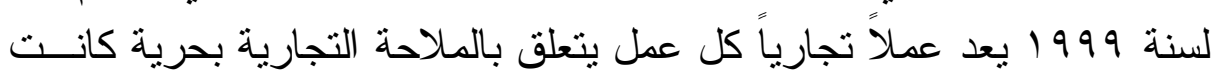

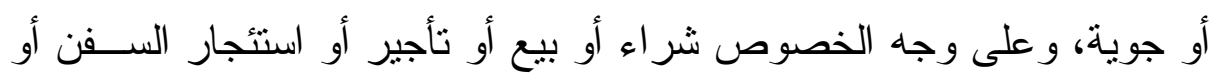

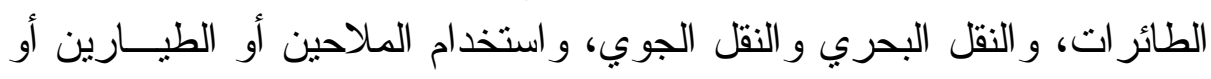

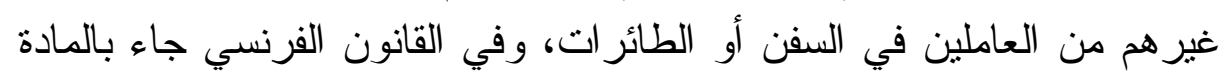

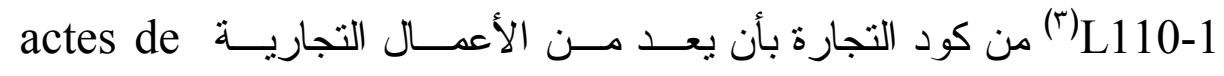

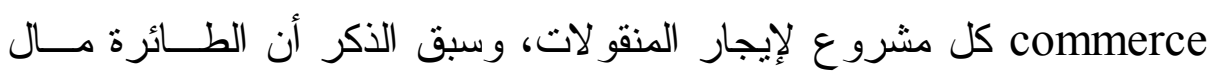

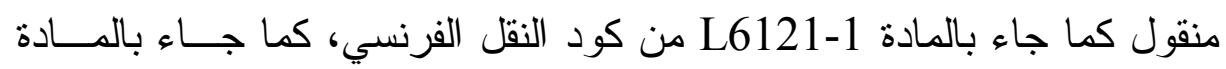

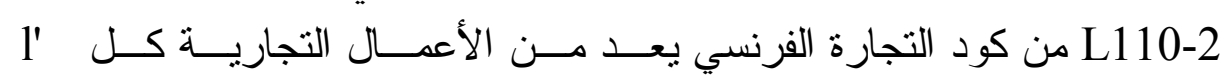

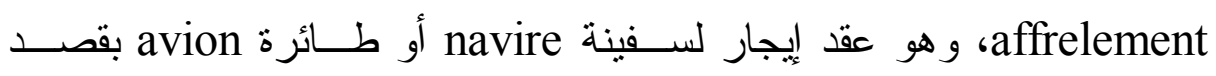

( ) Art. L6111-1 du code des transports.

(') د. حمد اله محمد حمد الله: النظام القانوني لإيجار الطائرة، دار النهضة العربية، سنة . . . T. $\left({ }^{3}\right)$ Art. L110-1 du code de commerce, modifé par loi n2013/100 du 28 Janvier 2013. 


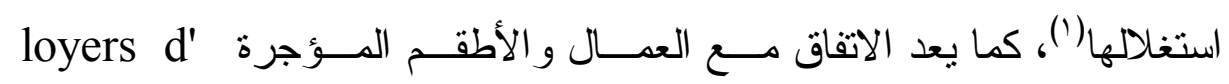
equipages

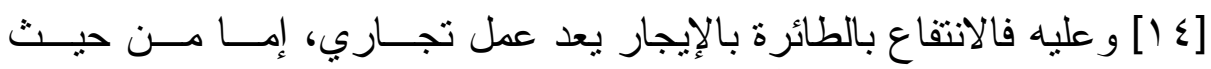

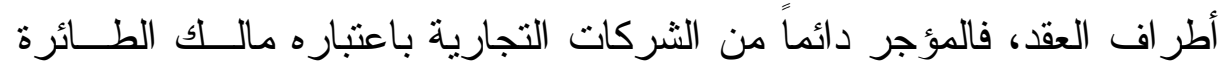

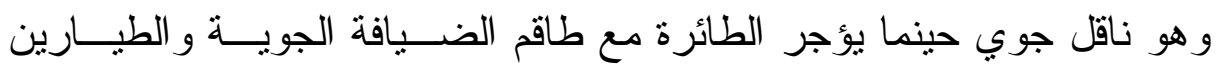

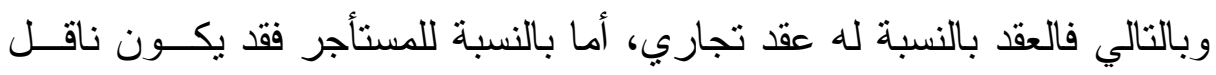

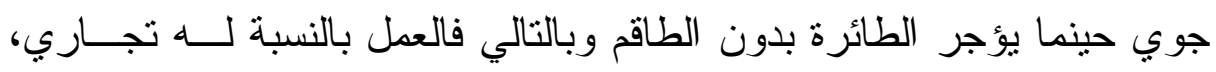

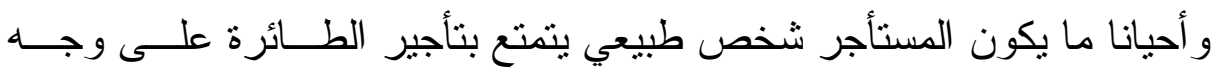

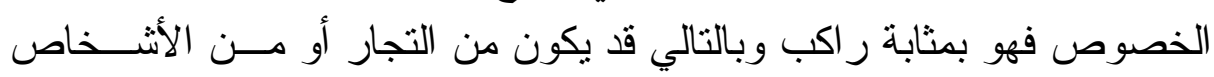

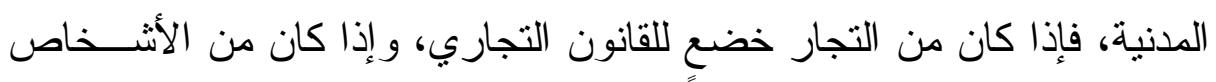

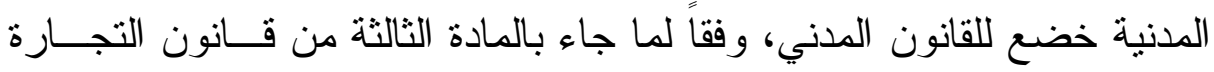

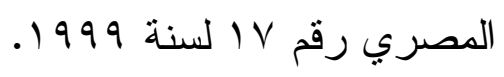
و عليه فإن الغالب في عقد إيجار الطائرة أنه عقد تجاري فيطبق بشأنه أحكـام

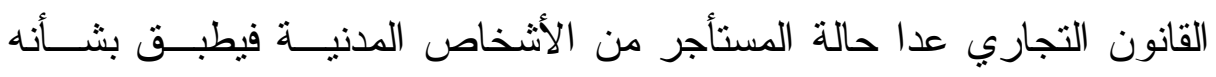
القانون المدني.

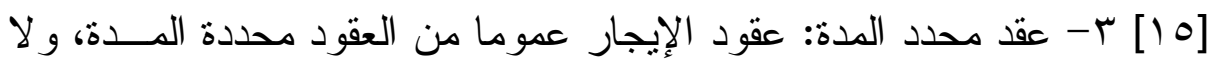

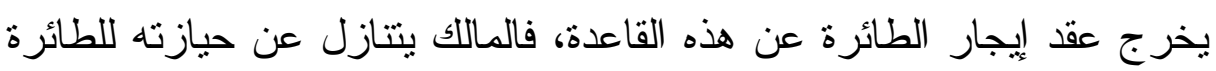

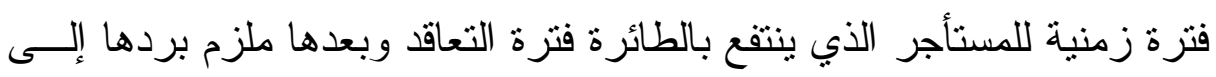

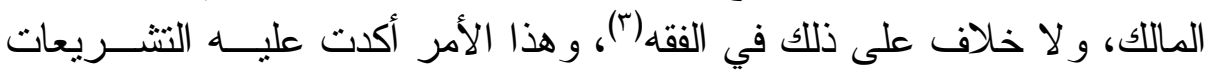

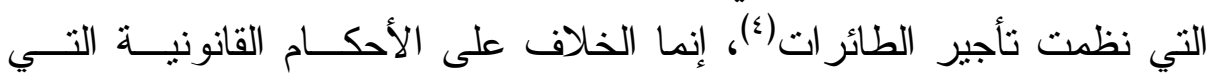

( $\left.{ }^{1}\right)$ Eric Roig, Définition d' affrètement, Juillet 2014, sur le site, static.com2.net/droit

$\left(^{2}\right)$ Art. L110-2 du code de commerce.

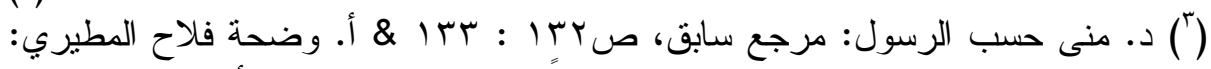

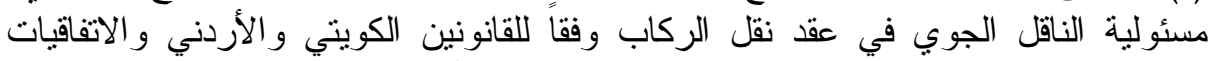

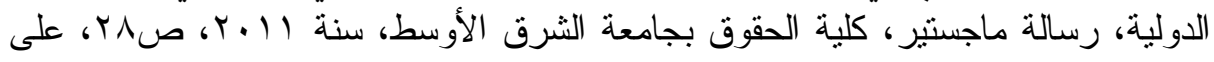
الموقع: \& www.meu.edu.jo/ar/images

Florent Vigny, Timothée Bertrand, op. cit., p. 20.

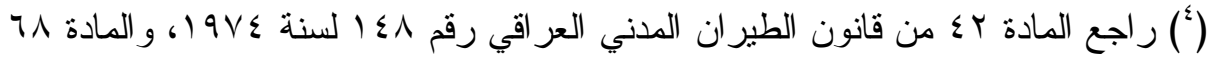

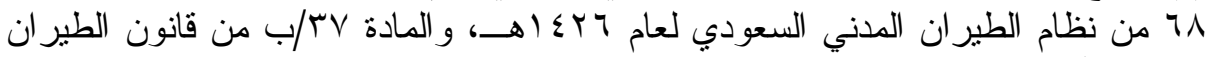

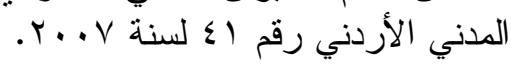


تخضع لها مدة الإيجار وتحديد المسئول عن أضر ار الطائرة التي تحدثها للغير

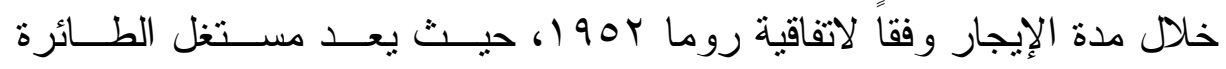

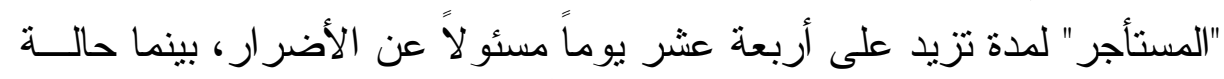

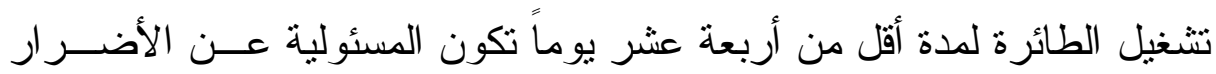

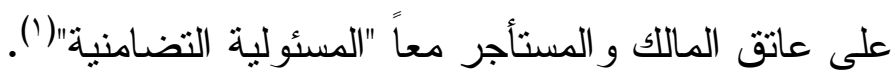

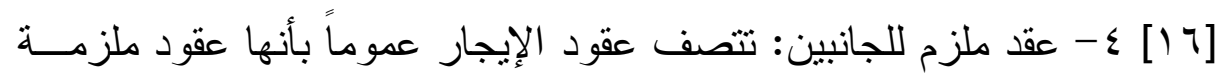

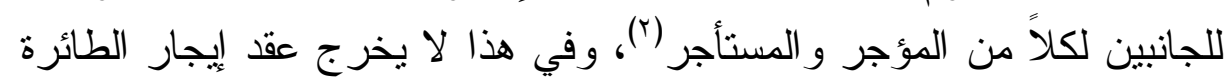

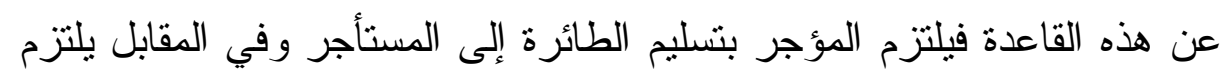
المستأجر بدفع الأجرة أو المكافأة المتفق عليها.

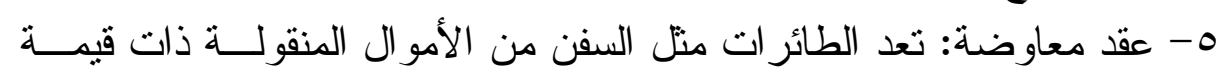

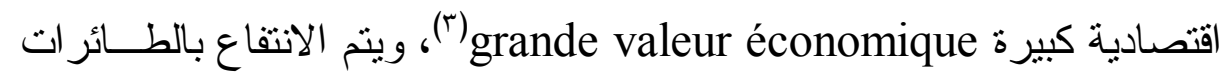

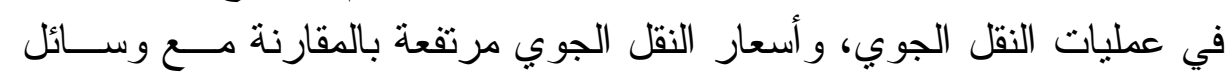

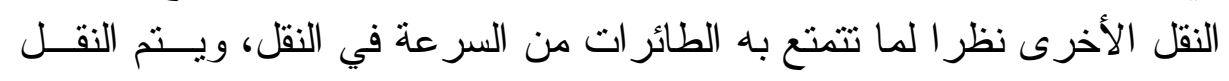

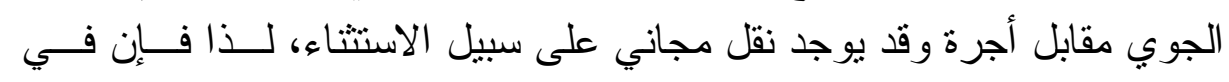

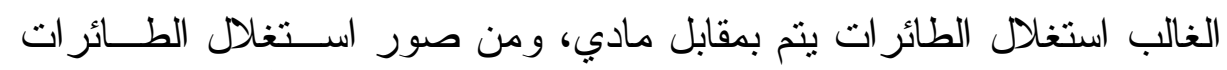

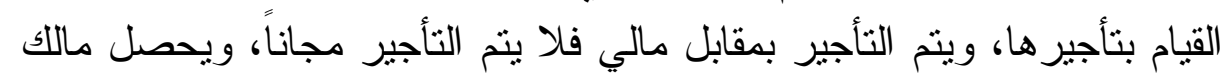

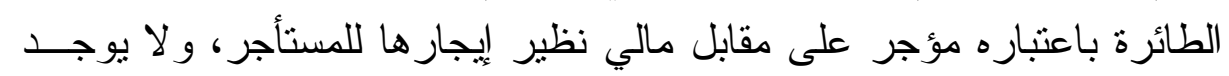

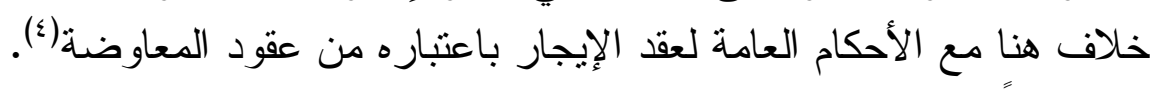

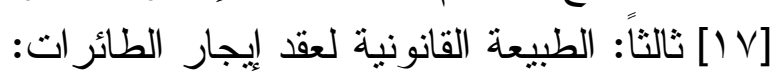

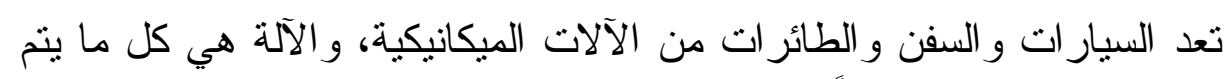

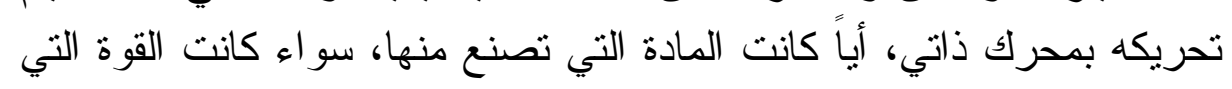

$$
\begin{aligned}
& \text { (') د. دمنى حسب الرسول: مرجع سابق، ص كזب ا. }
\end{aligned}
$$

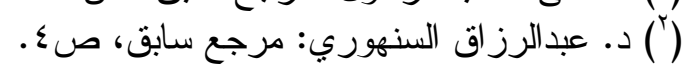

$\left({ }^{3}\right)$ Florent Vigny, Timothée Bertrand, op. cit., p. 2 \& Philippe Rodier,

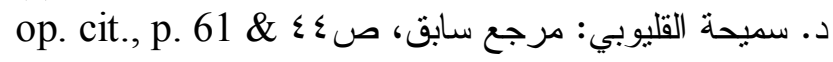

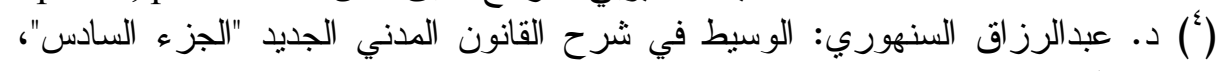

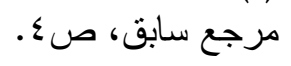


تحركها بخار اً أو كهرباء أو ماء أو هو اء، وتعتمد الطائر ات على الهو اء كقـــوة

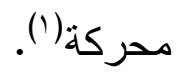

كما تعد الطائر ات من الأثياء غير الحية choses inanimées وهي أثتـياء

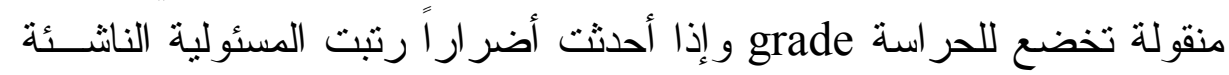

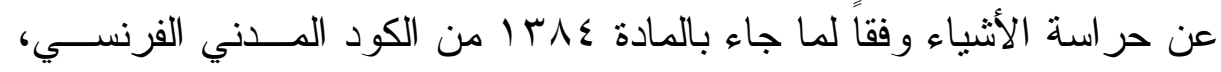

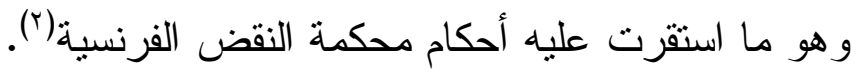

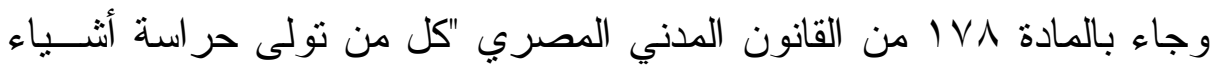

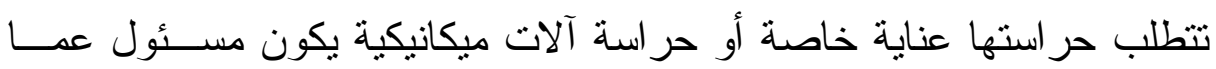

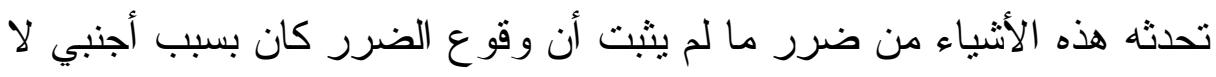
بد له فيه ...".

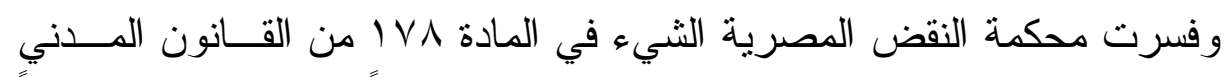

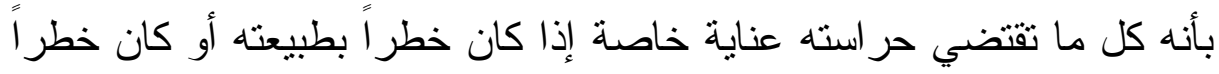

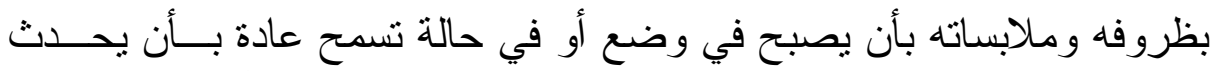

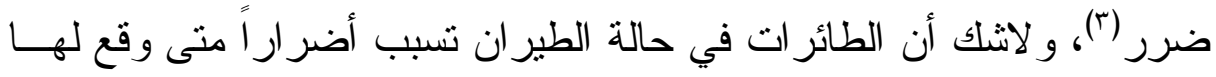

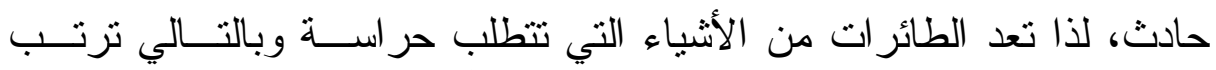

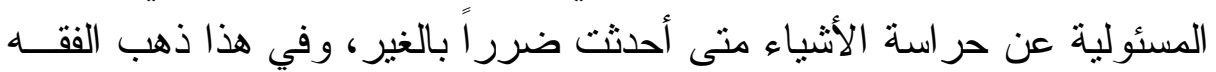

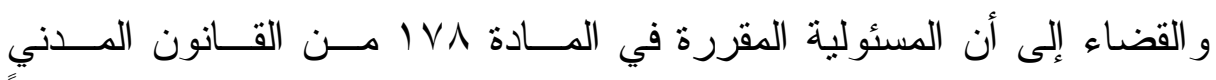
المصري ثقوم على أساس الخطأ المفترض وقو فئه من حارس الثيء الفتر اضاً

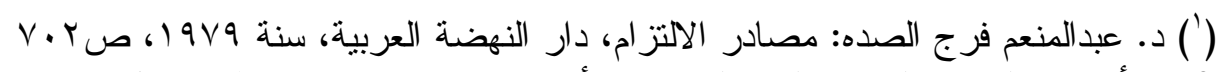

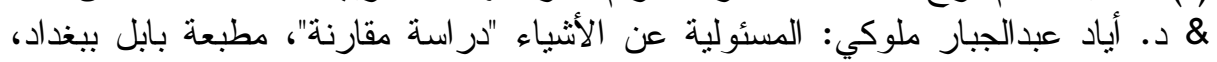

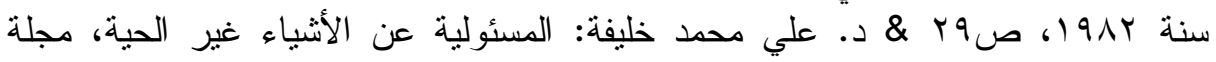

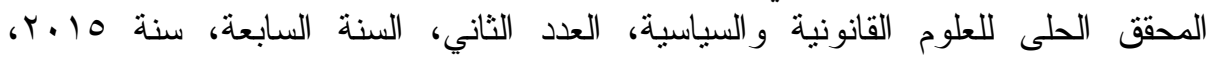

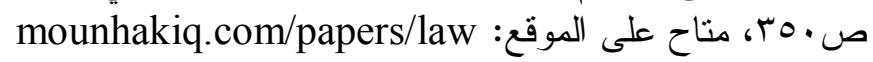

$\left(^{2}\right)$ Cass. Civ, 4 Février 2016, N14-29839 \& Cass. Civ, 11 Septembre 2014, N13-21459 \& Cass. Civ, 27 Février 2007, N03-16683 \& Cass. Civ, 5 Juillet 2001, N99-11520 \& Cass. Civ, 6 Juin 1990, N88-18991 \& Cass. Civ, 20 Juin 1973, N72-10788 \& Cass. Civ, 2 Mars 1971, N6812375 \& Cass. Civ, 26 Février 1970, N69-10185, les sentences sur les site, www.legifrance.gouv.fr

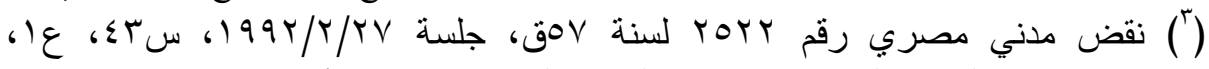

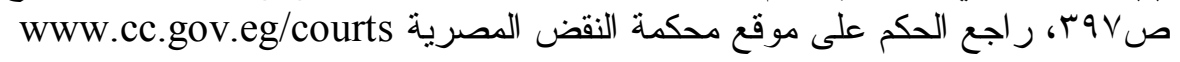


لا يقبل إثبات العكس، وترتفع عنه المسئولية إذا أثنبت أن وقوع الضــرر كــان

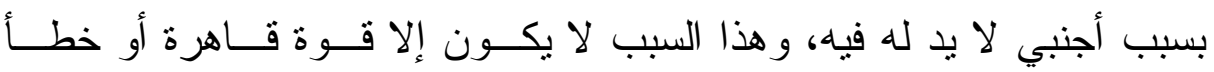

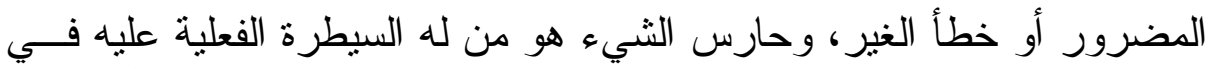

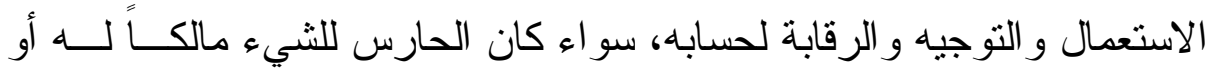

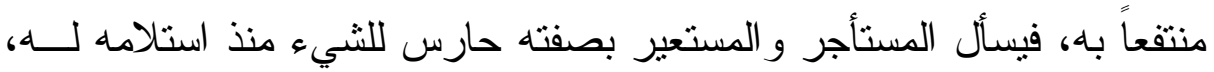

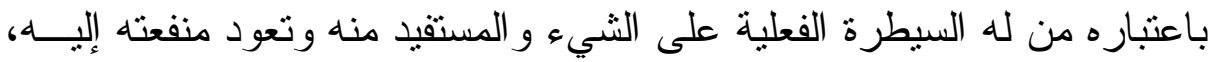

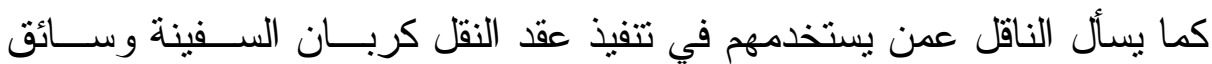
الطائرة أو السيارة، مسئولية الإنسان عن أفعال تابعيه (')

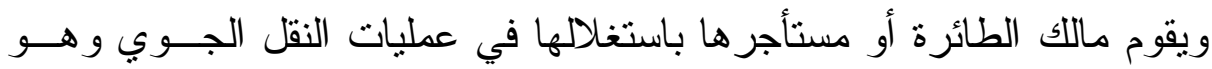

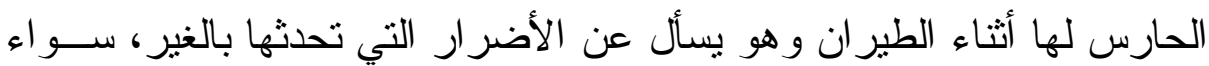

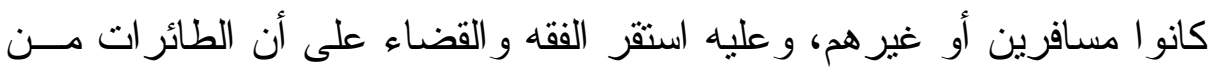

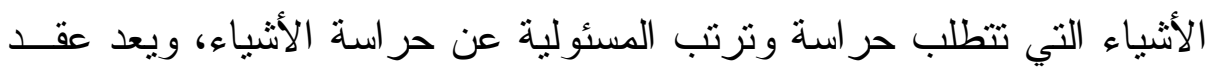
إيجار الطائر ات من عقود إيجار الأثــياء louage des choses، و الأشـــياء

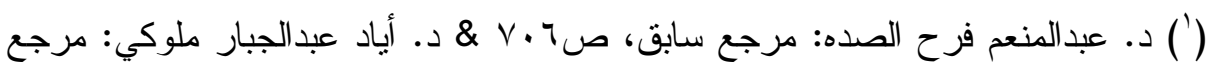

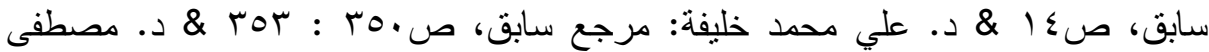

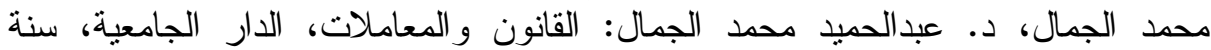
19AV

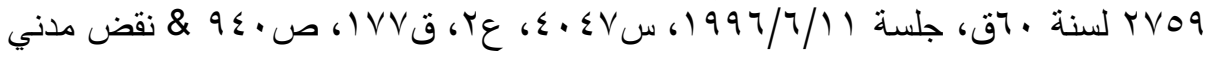

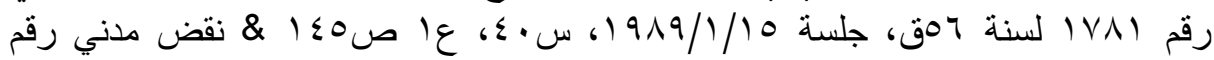

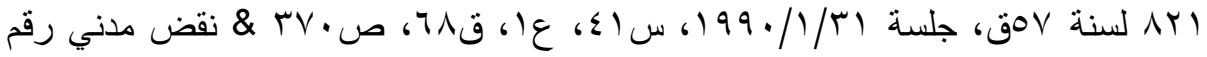

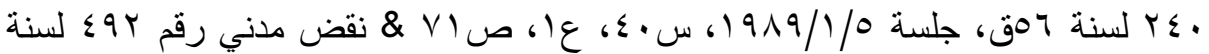
10

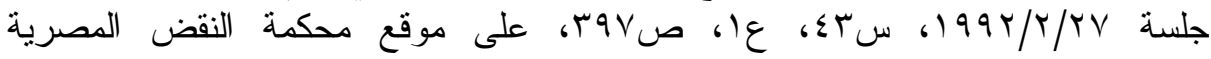


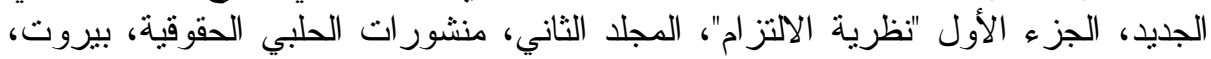

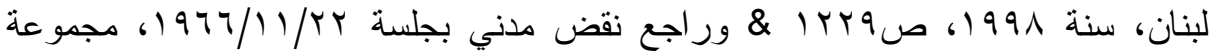

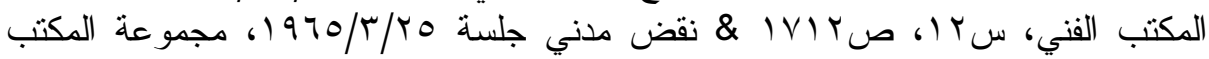

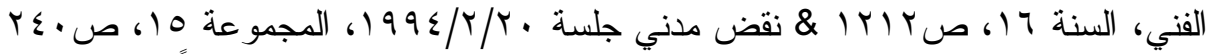

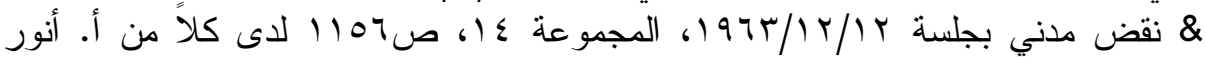

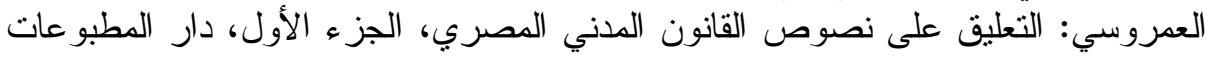

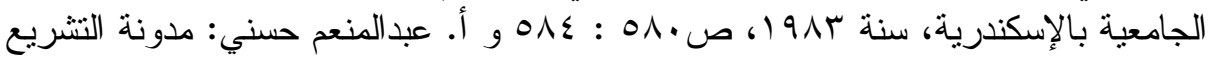

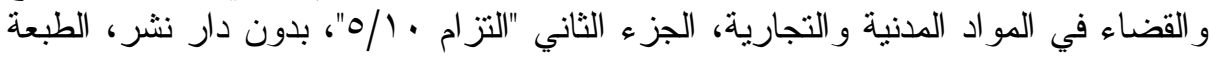

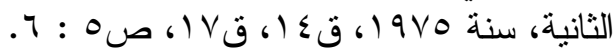


تحت الحر اسة ترتب المسئولية عن ضرر الأشياء، ويطبق ذلك على حــو ادث

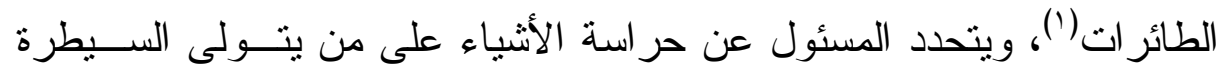

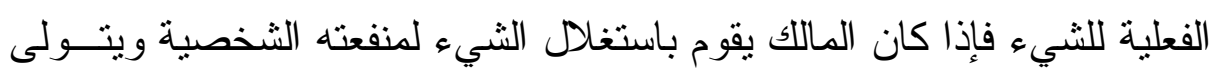

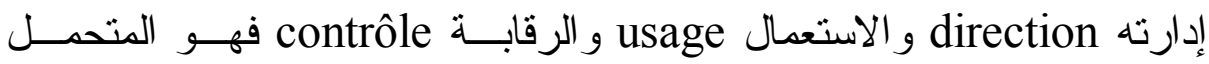

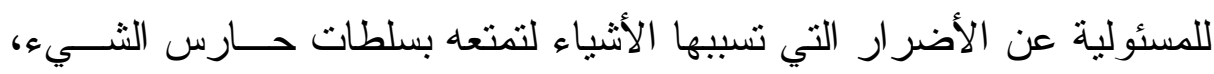

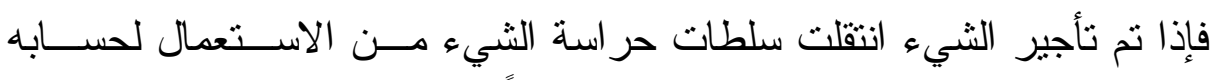

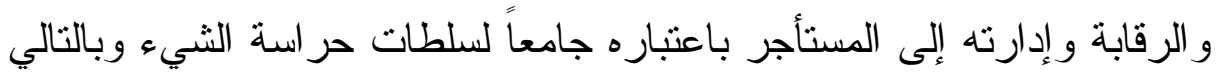

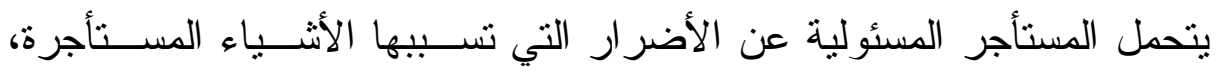

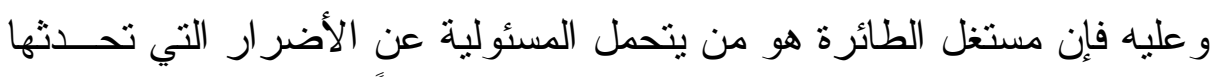

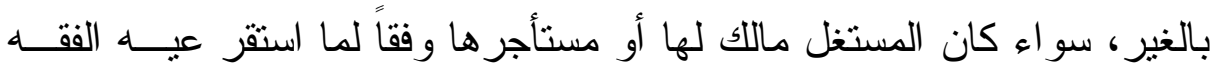

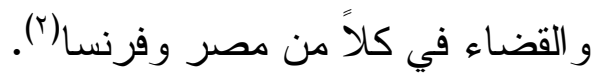

( $\left.{ }^{1}\right)$ Philippe Rodier, op. cit., pp. 98:101 \& Cass. Civ, 5 Juillet 2001, N99-11520 \& Cass. Civ, 6 Juin 1990, N88-18991 \& Cass. Civ, 2 Octobre 2007, N06-14121 \& Cass. civ, 2 Mars 1971, N68-12375 \& Cass. Civ, 26 Février 1970, N69-10185, les sentences sur le site, www.legifrance.gouv.fr \&

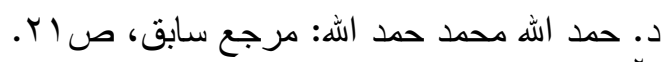

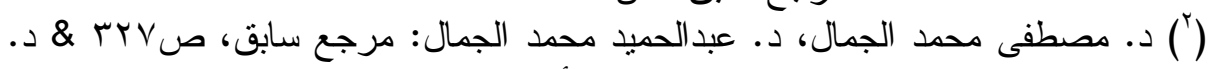

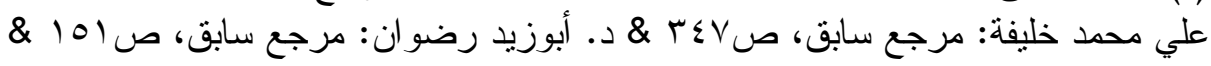

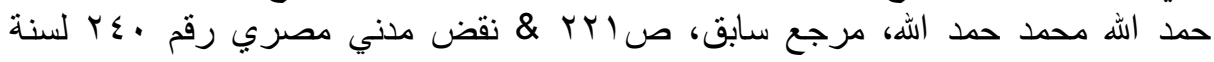

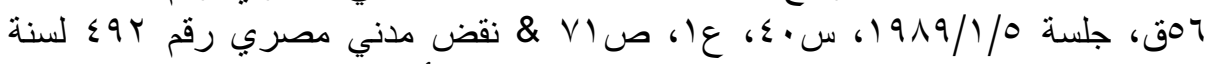

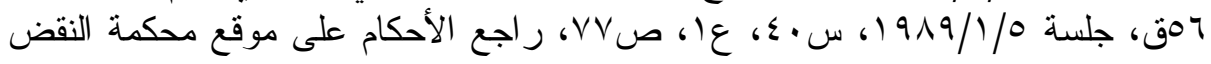

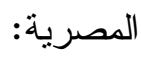
www.cc.gov.eg/courts \& Cass. Civ, 11 Septembre 2014, N13-21459 \& Cass. Civ, 15 Janvier 2014, N12-12159 \& Cass. Civ, 12 Avril 2012, N10-20831 et N10-21094 \& Cass. Civ, 1 Décembre 2005, N04-15287 \& Cass. Civ, 8 Juin 1994, N92-18110 \& Cass. Civ, 7 Février 1990, N88-19882 \& Cass. Civ, 18 Juin 1975, N74-10696 \& Cass. Civ, 5 Avril 1973, N71-14090 \& Cass. Civ, 28 Mars 1973, N72-11833, les sentences surle site, www.legifrance.gouv.fr \& Gabriel Seignalet, op. cit. 


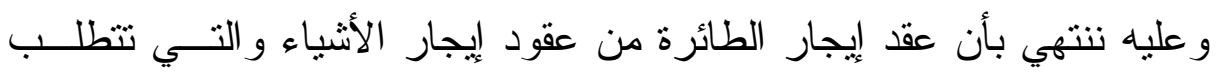

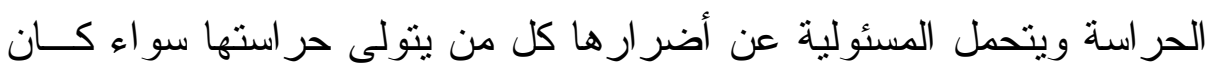
ذللك مالكها أو مستأجر ها.

\section{الفرع الثاني \\ أهمية عقد إيجار الطائر ات النان}

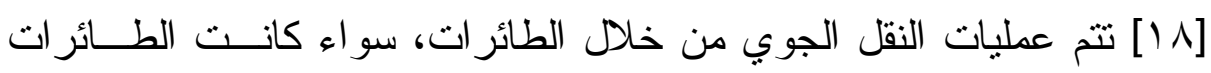

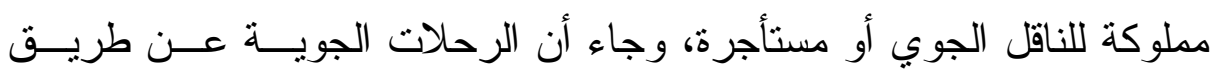

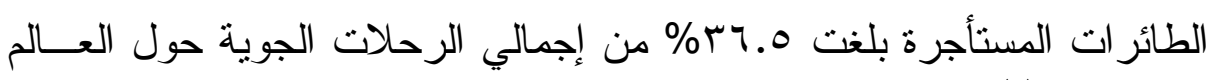

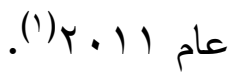

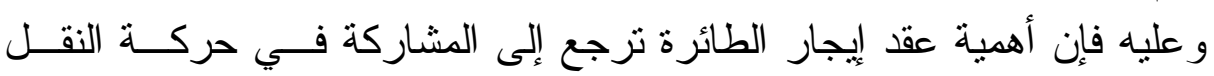

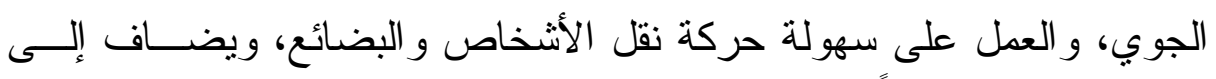

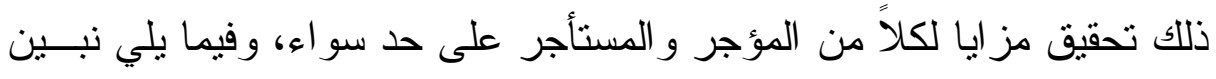
ذلك.

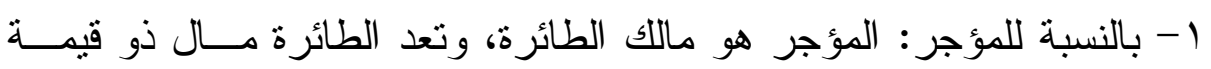

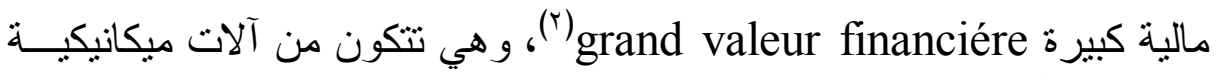

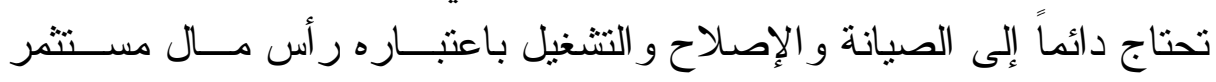

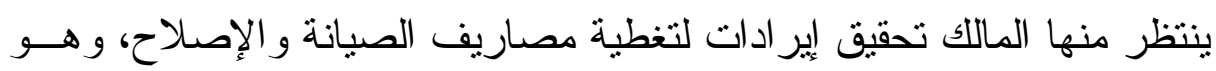

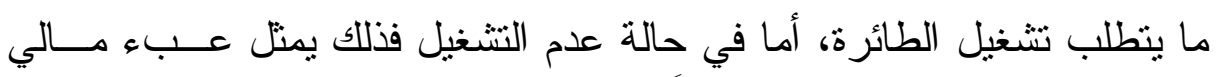

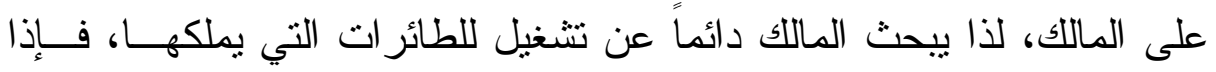

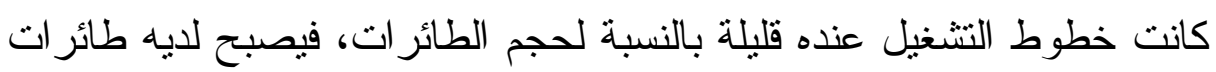

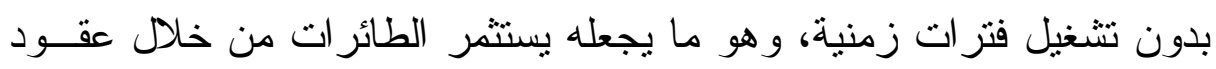

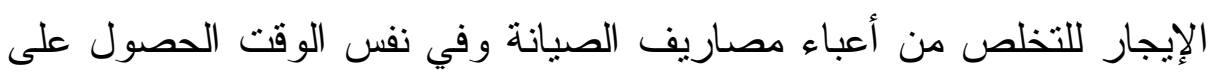

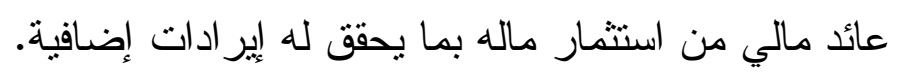

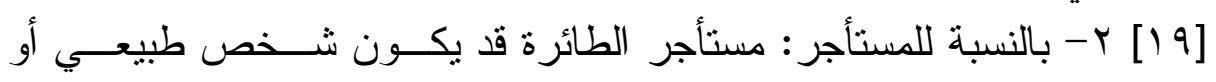

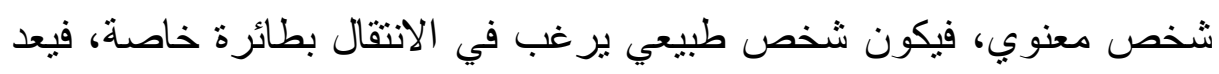

(1) Philippe Rodier, op. cit., p. 23.

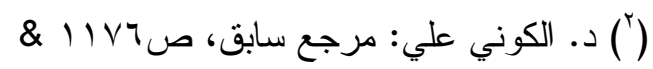
Florent Vigny, Timothée Bertrand, op. cit., p. 2 \& Philippe Rodier, op. cit., p. 59. 


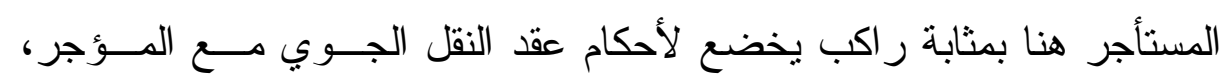

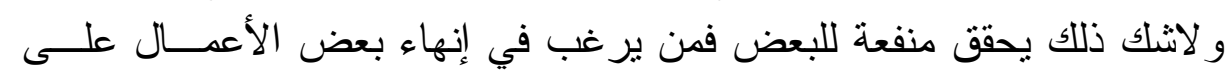

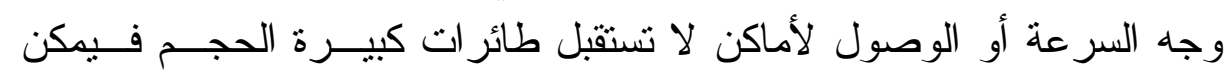

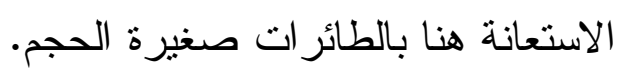

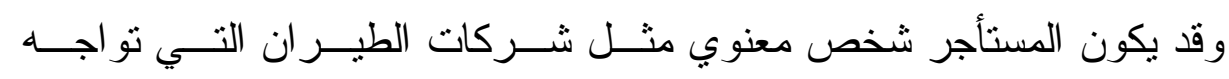

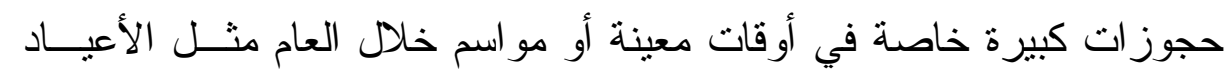

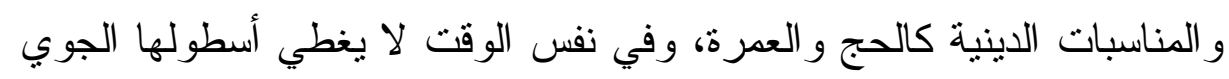

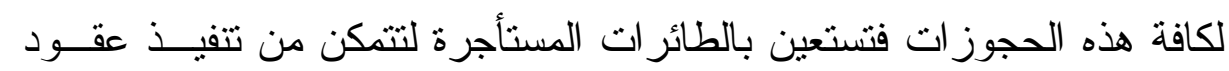
النقل مع الركاب في الآجل القصير (').

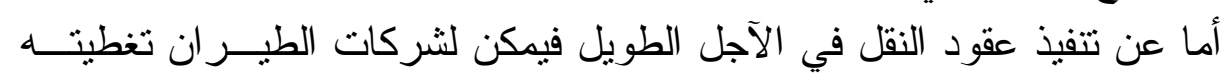

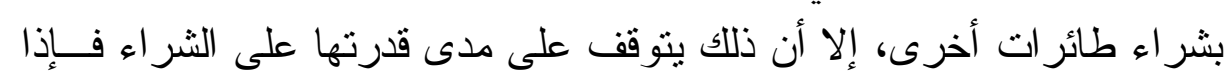

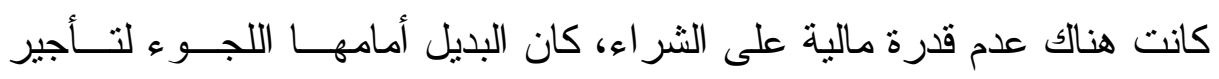
الطائر ات.

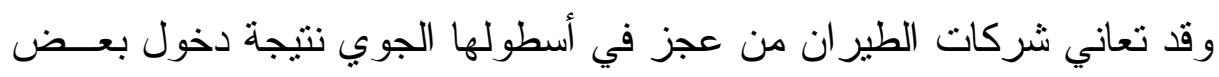

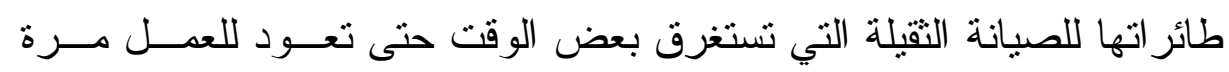

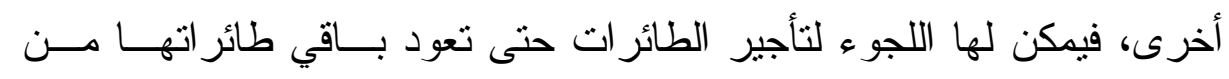

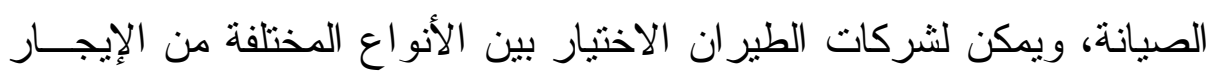

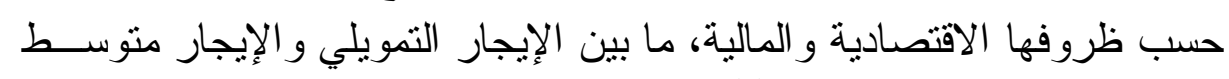
الآجل، والإيجار قصير الآجل(؟).

\section{الفرع الثالث}

تكوين عقد إيجار الطائرات

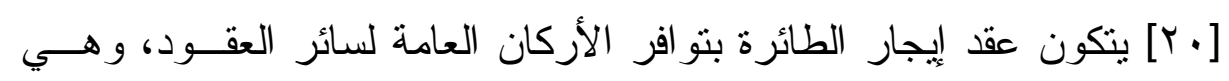
الرضا لطرفي التعاقد و المحل و السبب، وفيما يلي نبين ذلك في النقاط التالية.

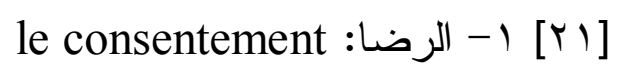

ويتحقق الرضا في العقد بتبادل طرفان التعبير عن إر ادنين متطابقتين، و الرضا

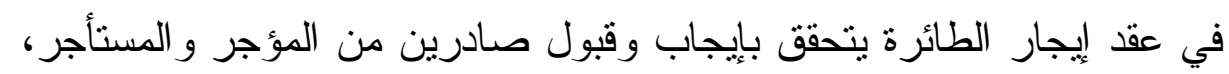

(') أ. وضحة فلاح المطيري: مرجع سابق، ص ع \& \& د. حمد اله محمد حمد الله: مرجع

() Philippe Rodier, op. cit., p. 93 et p. 148. 
و لابد أن يتخذ التعبير عن إر ادة الطرفين شكل معين بالكتابة، فعقــد الإيجــار

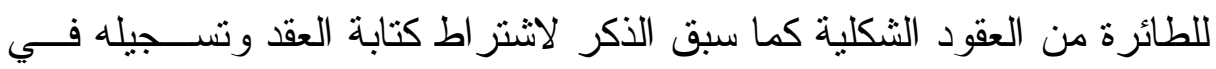

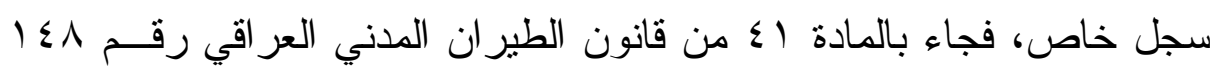

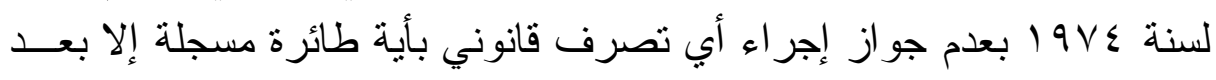

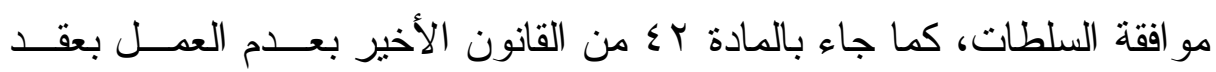

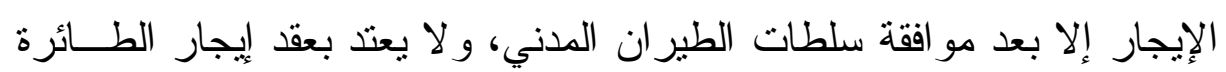
أو إيجار سعتها ما لم يكن خطياً) '(1).

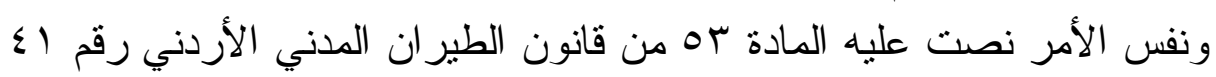

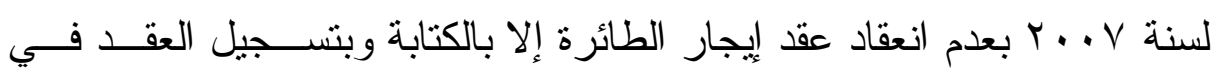

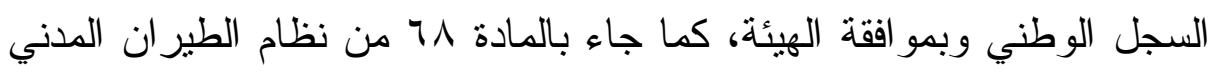

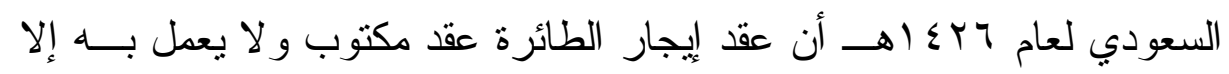
بعد مو افقة الهيئة.

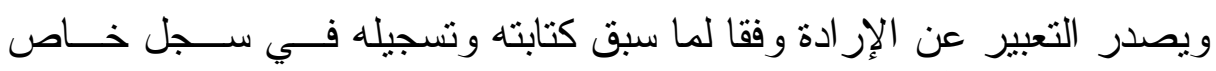

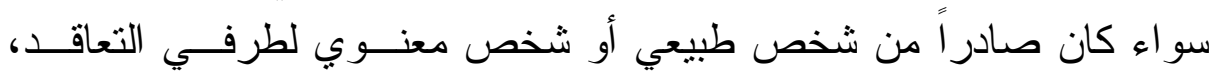

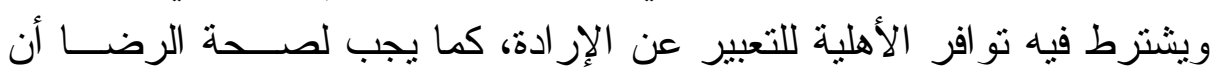

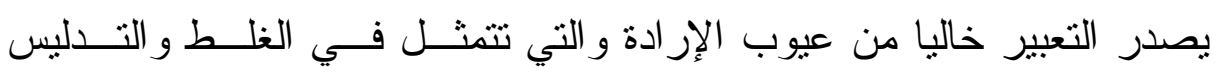
و الإكر اه و الاستغلال (r). l' objet : المحل

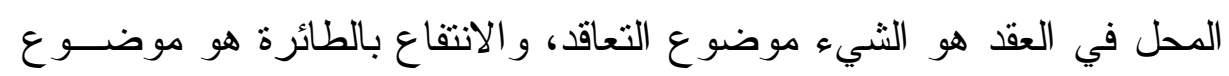

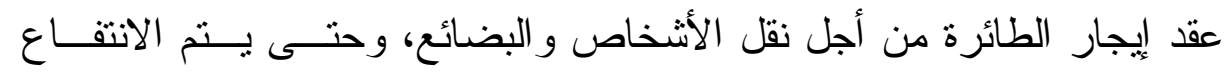

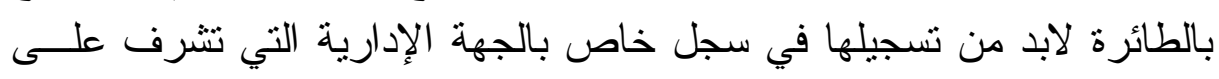

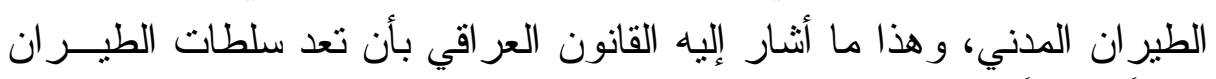

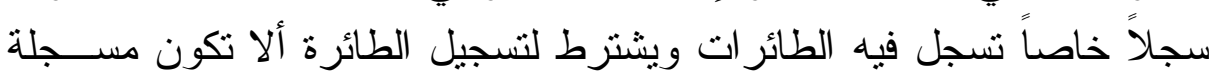

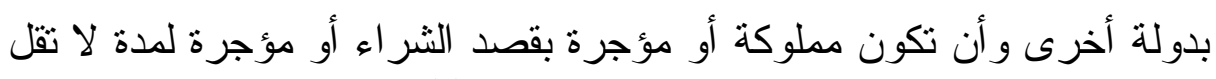
عن ستة أثنهر لأشخاص يتمتعون بجنسية الدولة|(r)، كما جاء بالقانون الأردني

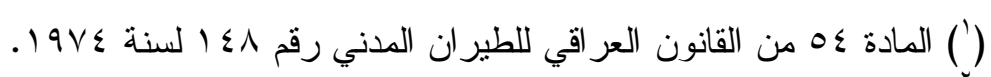

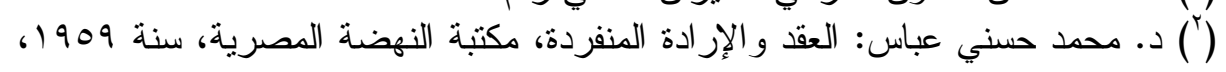

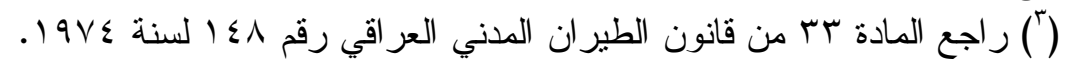


يسجل في السجل الوطني الطائر ات المملوكة لأثــخاص يتمتعــون بالجنســية

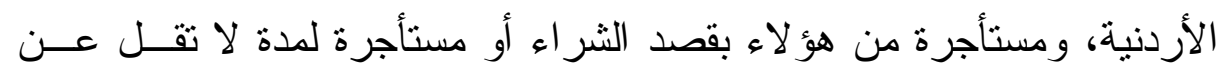

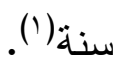

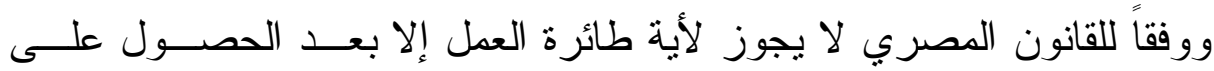

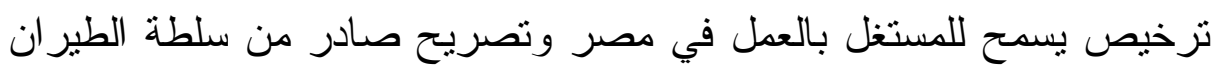

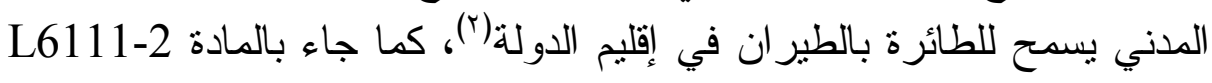

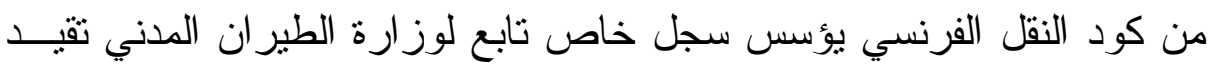

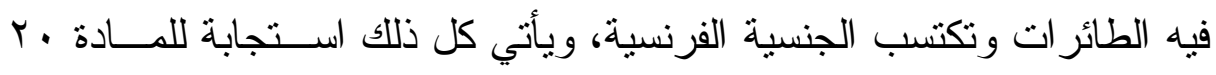

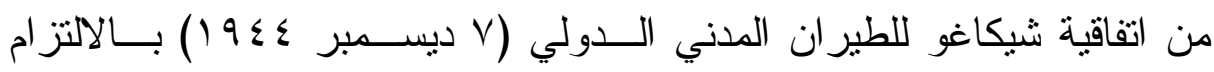
بتسجيل الطائر ات (r).

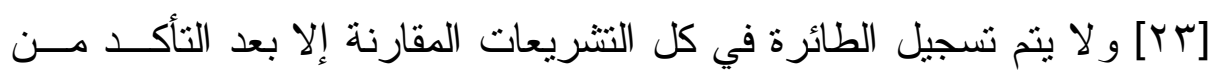

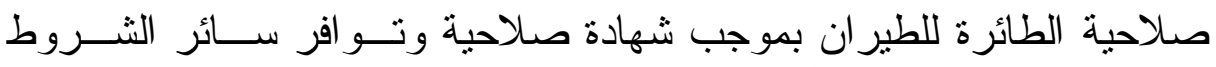

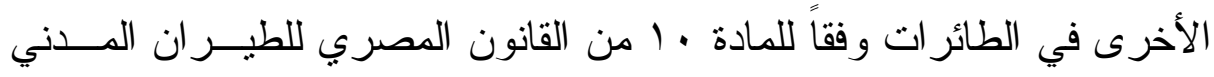

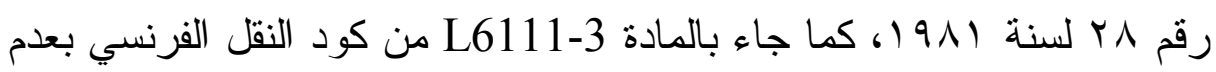

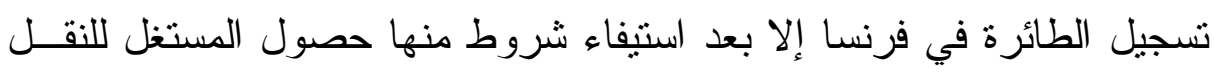

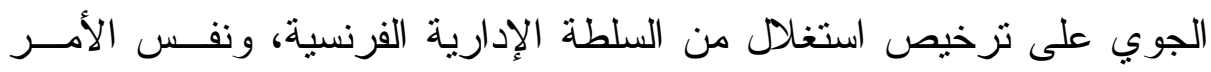

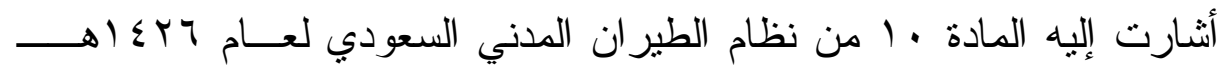

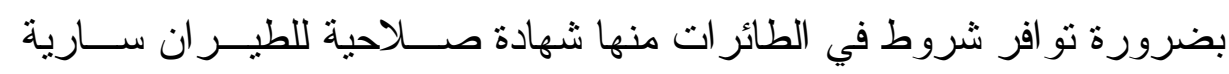
المفعول وصادرة من الدولة المسجلة فيها.

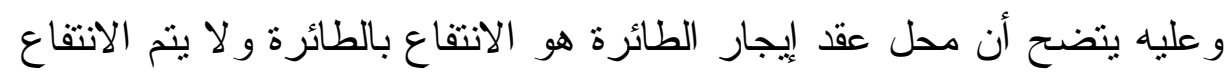

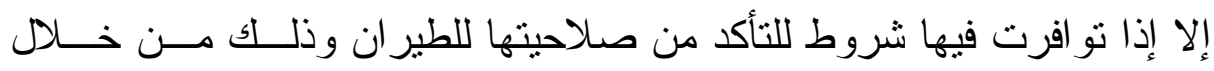

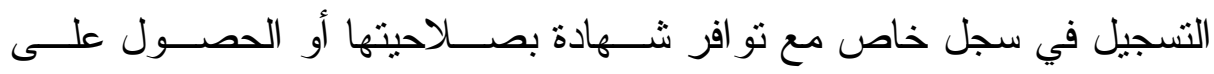

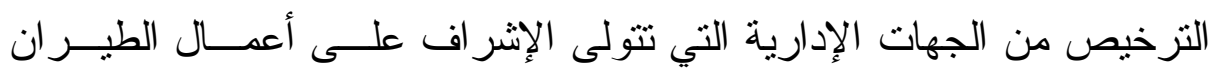
المدني.

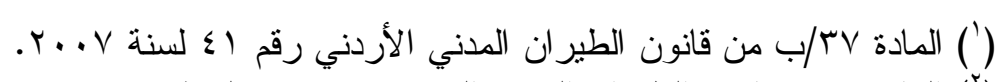

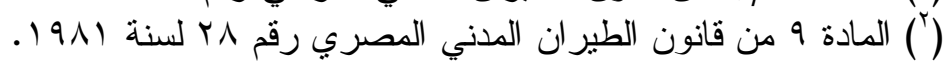
$\left(^{3}\right)$ Florent Vigny, Timothée Bertrand, op. cit., p. 2 \& Michel Asencio, l' utilisation civile des drones-problémes techniques, opertionnels et juridiques, 28 Mars 2008, sur le site www.frstrategie.org/publications, p. 4 \& Philippe Rodier, op. cit., p. 85. 


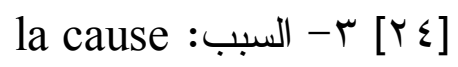

يقصد به الباعث الدافع cause impulsivo إلى التعاقد، ويشترط في الســـب

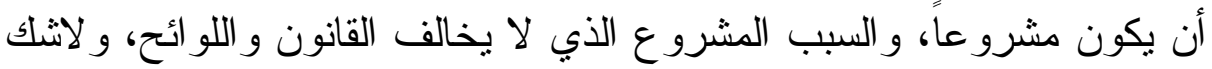

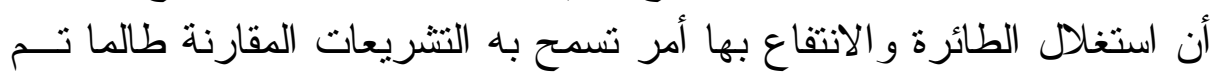

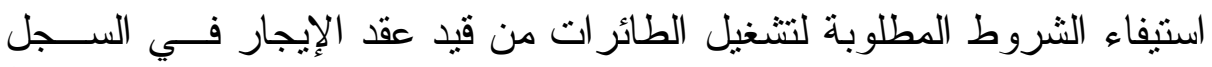

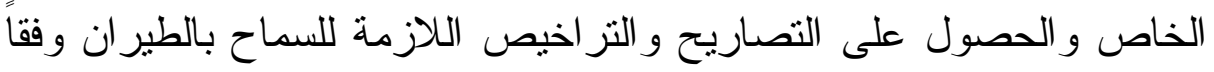

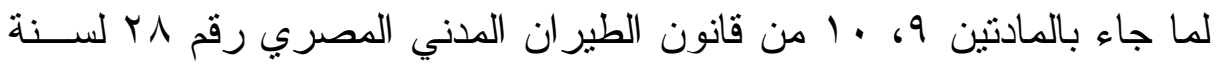

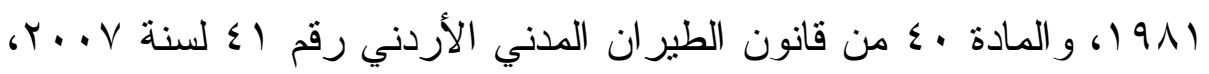

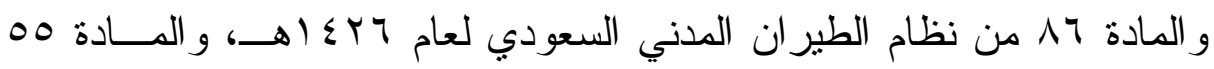

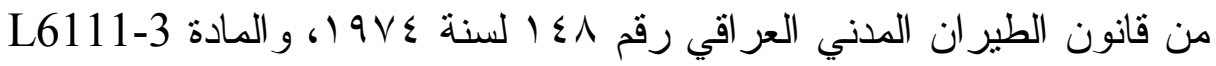

$$
\text { من كود النقل الفرنسي. }
$$

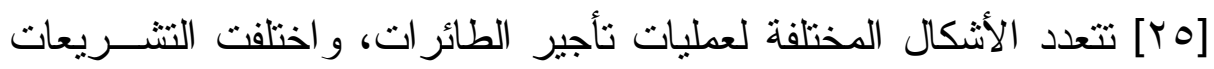

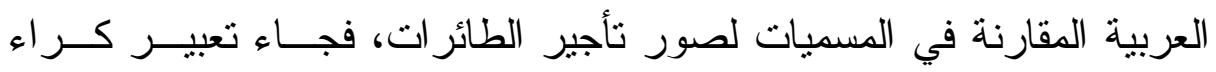
الطائرة وهو إيجار طائرة دون طاقم الملاحة الجوية، وتعبير إيجــار الطـائرة

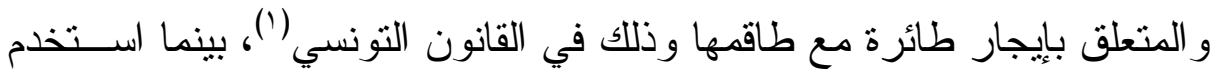

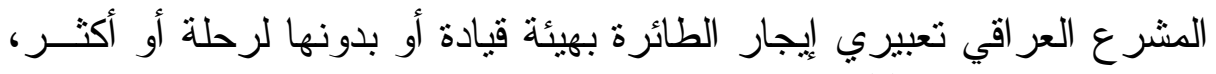

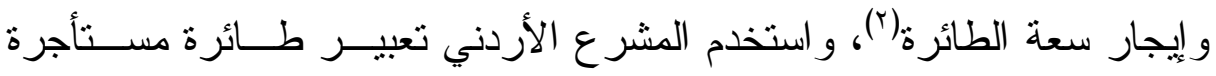

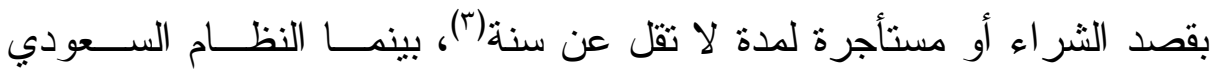

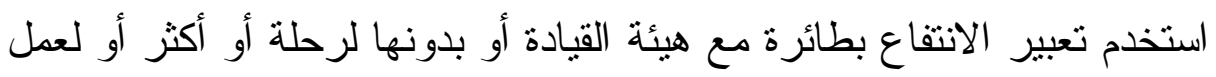

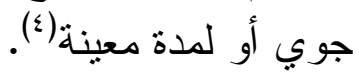

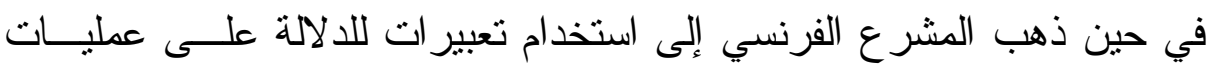

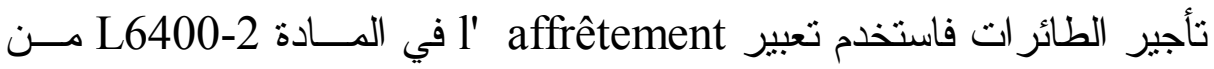

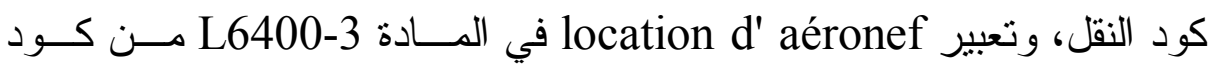

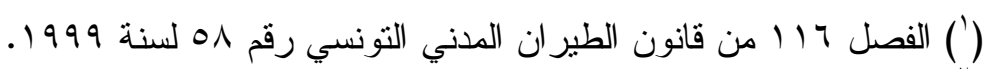

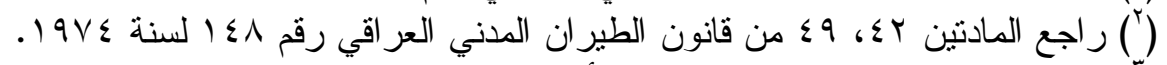

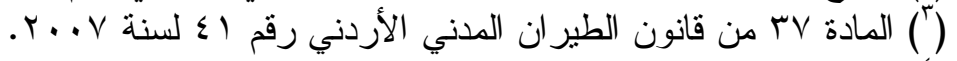

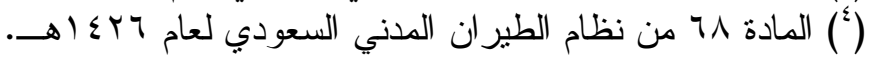




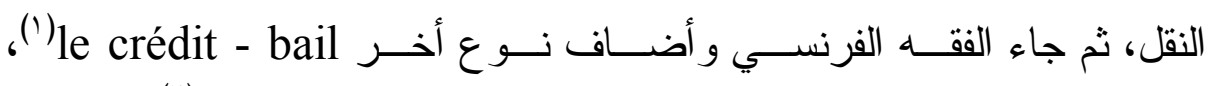
و المختلف في ترجمته ما بين الائتمان الإيجاري و الإيجار التمويلي (؟).

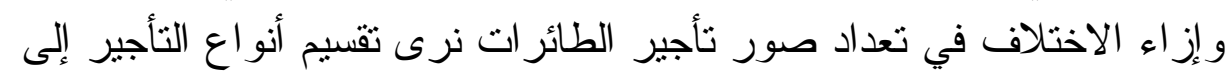

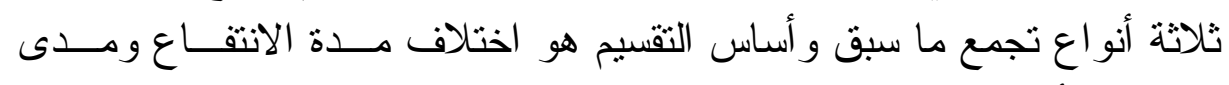

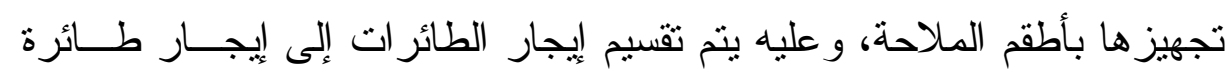

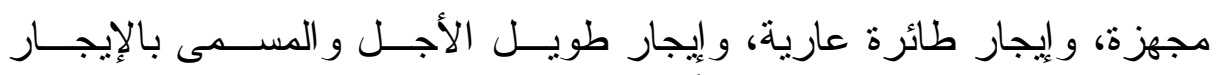

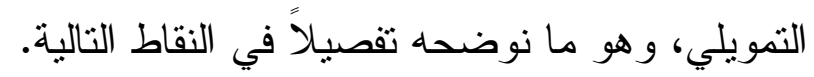

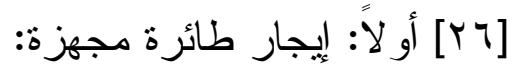
عقود إيجار الطائرة في هذا النوع يتم لمدة زمنية قصيرة لائرة لا نتجاوز ستة أثنهر

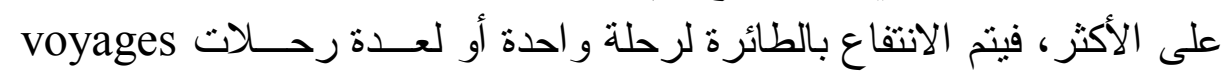

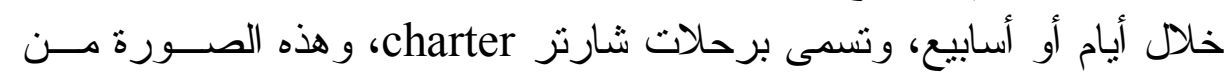

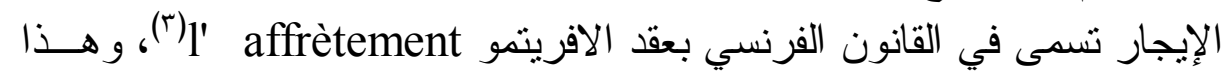

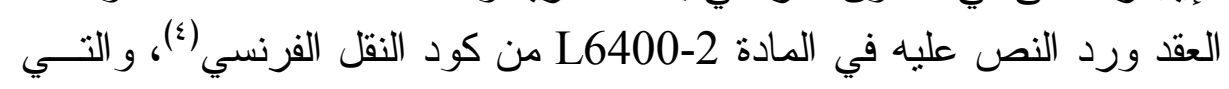

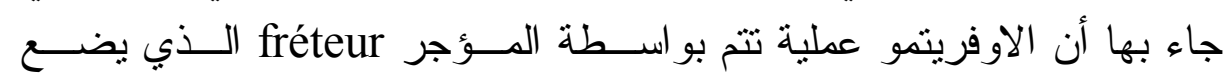

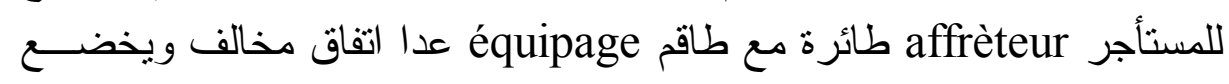
الطاقم لإدارة المؤجر fréteur. [YV] ويتميز هذا العقد بعدة خصائص أخرى بخلاف مدة الاستخلال القصيرة،

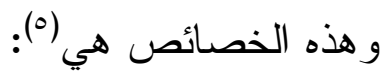

( $\left.{ }^{1}\right)$ Philippe Rodier, op. cit., p. 93 \& Florent Vigny, Timothée Bertrand, op. cit., p. 9.

(') د. إبراهيم الدسوقي أبو الليل: الإيجار المنتهي بالتمليك في القانون الوضعي و الفقانه

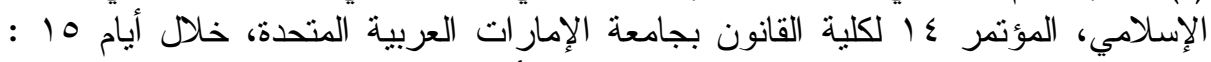

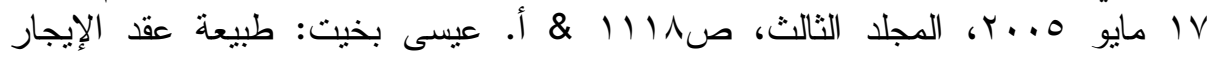

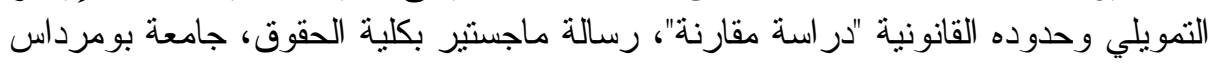

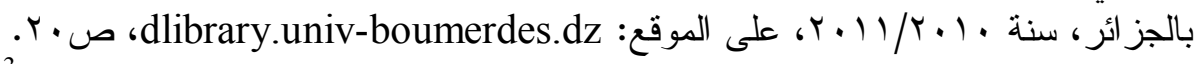
$\left(^{3}\right)$ Philippe Rodier, op. cit., p. 144.

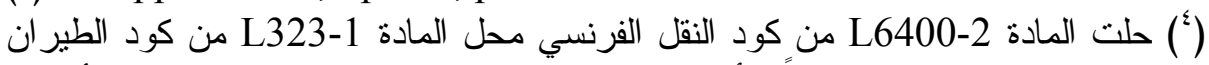

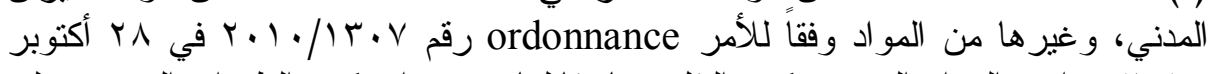

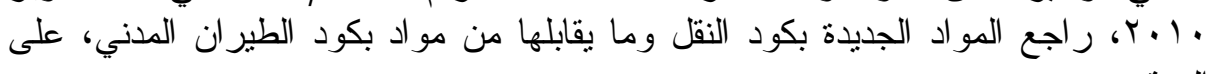
www.droitaerien.com

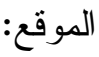

( $\left.^{5}\right)$ Philippe Rodier, op. cit., pp. 146:154. 


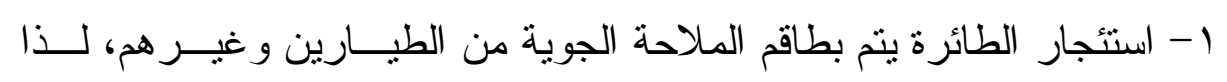
يسمى العقد بالإيجار الثامل wet lease.

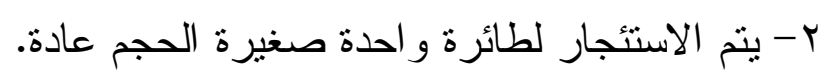

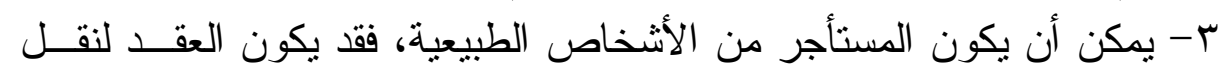

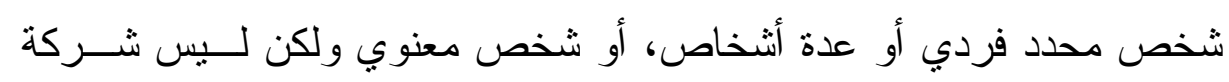
طير ان. ع - يعد العقد من عقود المقاولة contrats d' entreprise.

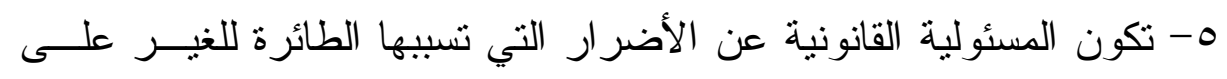

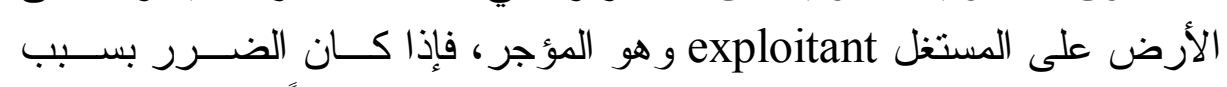

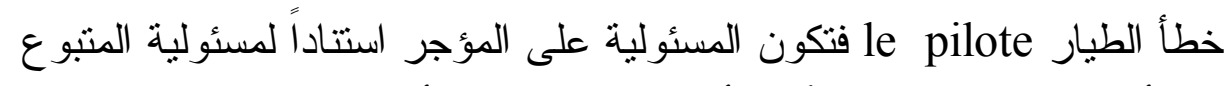

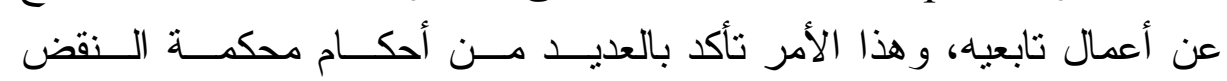
الفرنسية(') (1)

7- الالتز ام بالنقل الجوي يقع على عاتق المستغل للطائرة وهو المؤجر، بينما

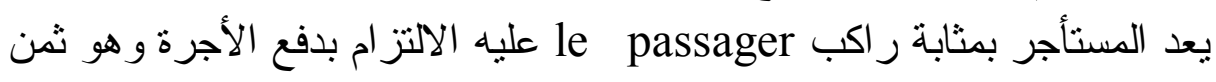

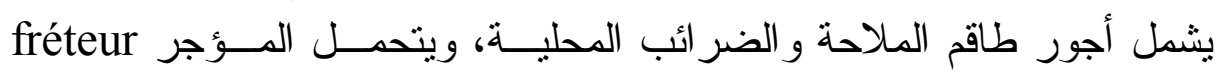

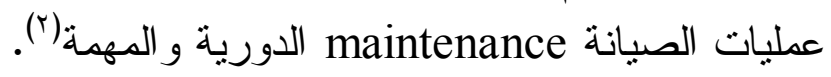

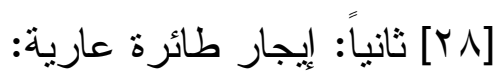

ويسمى بالإيجار البسيط Simple location، ومدته تنر اوح ما بئه بين ستة أثنهر إلى خمس سنوات، و هذه الصورة من الإيجار تسمى في القانون الفرنسي بعقد

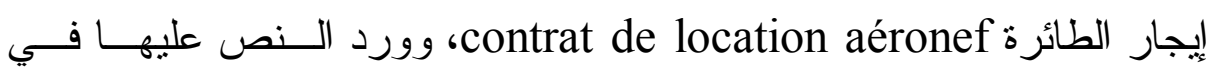

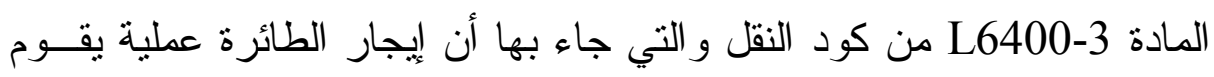
المؤجر bailleur بوضع طائرة بدون طاقم sans équipages تحت تصرف المستأجر المؤر (r) الم

( ${ }^{1}$ Cass. Com, 29 Septembre 2015, N14-11041 \& Cass. Com, 2 Octobre 2012, N11-21362 \& Cass. Com, 26 Mai 1999, N96-14505 \& Cass. Com, 2 Octobre 2007, N06-14121, les sentences sur le site, www.legifrance.gouv.fr

$\left({ }^{2}\right)$ Philippe Rodier, op. cit., p. 146 et p. 155.

(3) Florent Vigny, timothée Bertrand, op. cit., p. 20. 


\section{[Y9] ويتميز هذا النوع من الإيجار بالخصائص التالية(')}

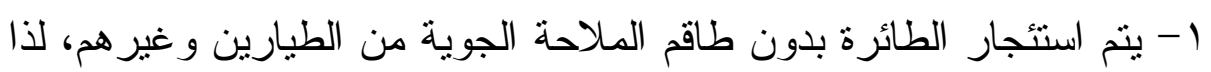

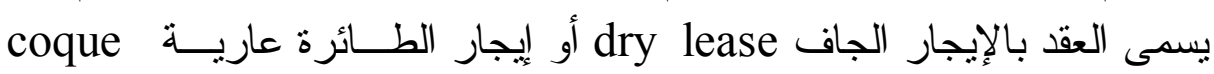
.nue

Y- بتم الاستئجار لعدة طائر ات تكون كبيرة الحجم عادة.

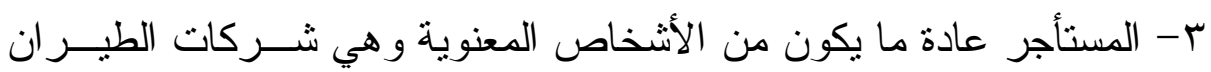
التي تلنزم بنقل الكثير من الأشخاص على على خطوطن التها.

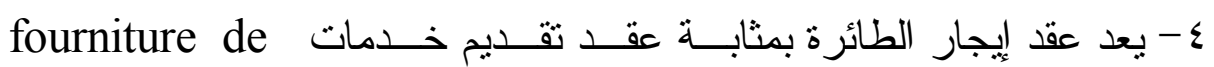
-services

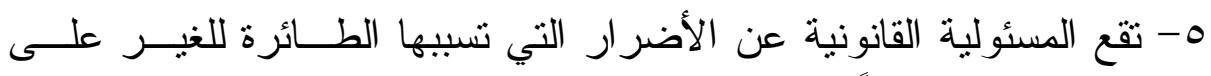

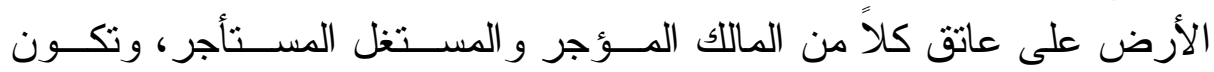

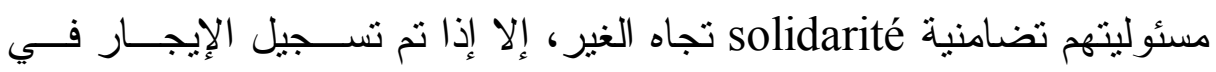

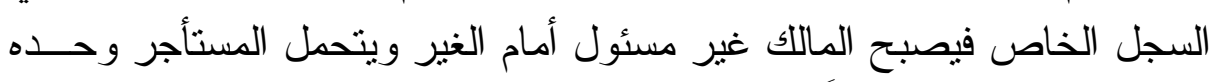

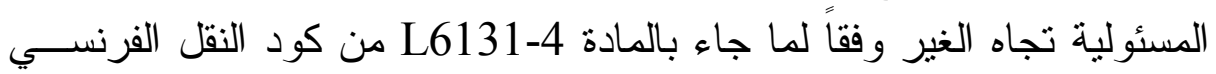

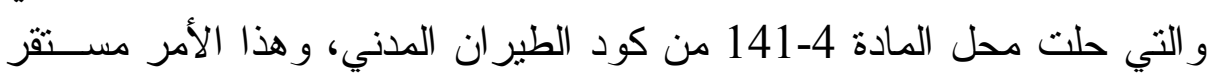
عليه في الفقه و القضاء الفرنسي (r). ؟- الالتز ام بالنقل الجوي يقع على عاتق المستأجر الذي عادة ما يكون شركة

$$
\text { [بير ان لها خطوط جوية. }
$$

يتمتع عقد الإيجار التمويلي بأهمية اقتصادية كبيرة حيث يعد أحد وسائل تمويل

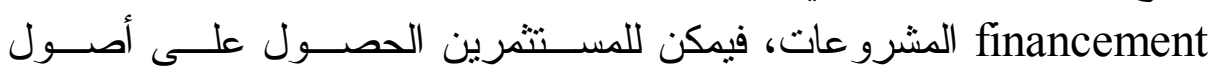

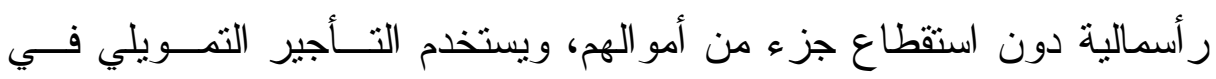

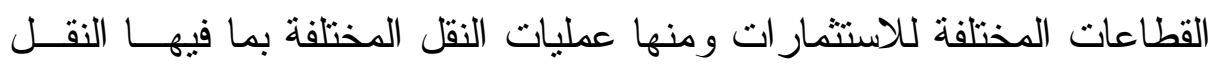

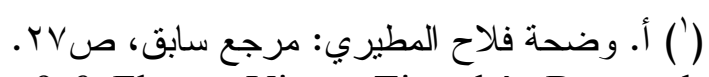

(') Michel Asencio, op. cit., p. 9 \& Florent Vigny, Timothée Bertrand, op. cit., p. 18 \& Cass. Civ, 12 Mai 2004, N01-14259 et N01-14931 \& Cass. Civ, 9 Octobre 1979, N78-12503, les sentences sur le site, www.legifrance.gouv.fr 
البحري و النقل الجوي، خاصة في ظل ارتفاع تكلفة الأصول الر أسمالية مثـلـل

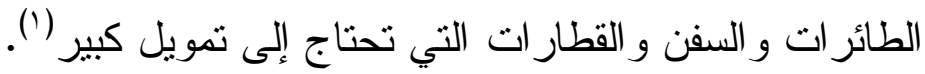

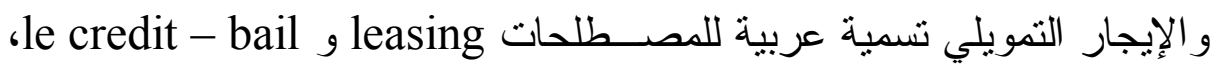

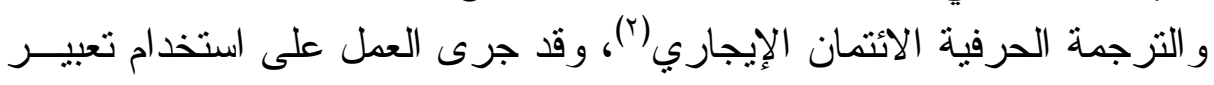

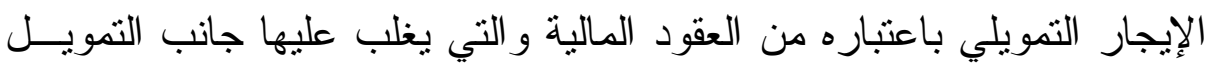
ل اللمشرو عات المختلفة.

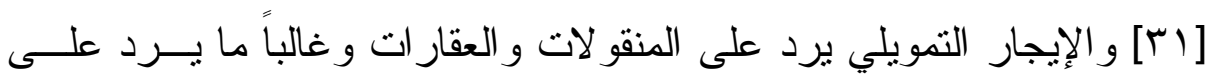

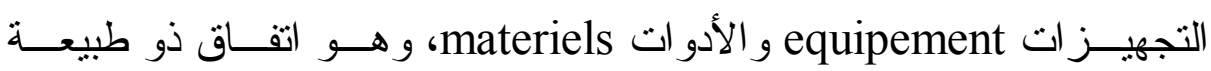

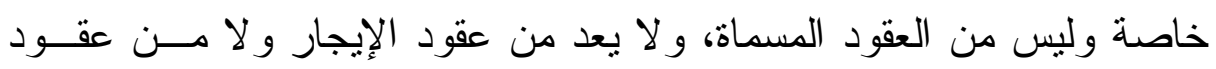

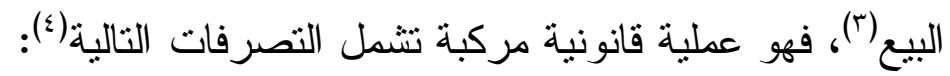

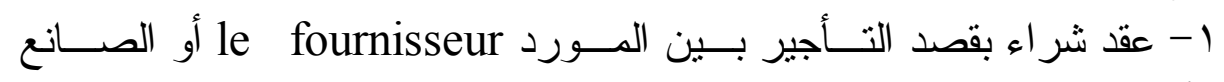

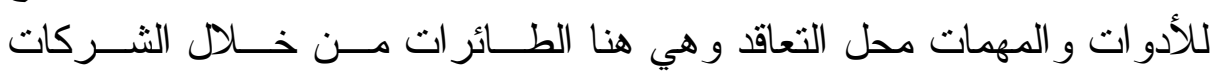

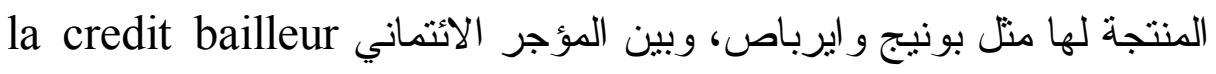

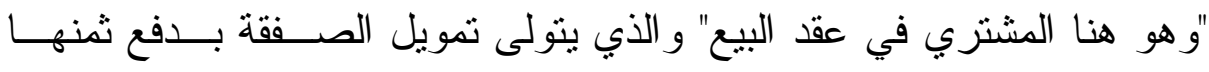

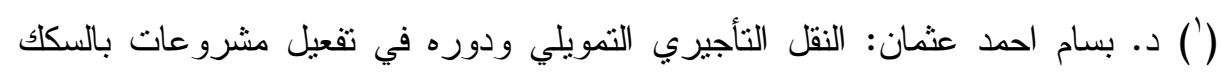

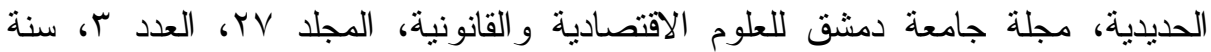

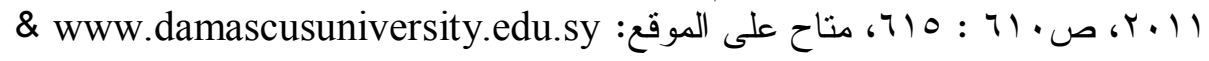
Jean - François Gervais, les clés du leasing, éditions d' organisation, 2004, p. 11, sur le site, www.eyrolles.com/chapitres \& Philippe Rodier, op. cit., p. 75 \& Florent Vigny, timothée Bertrand, op. cit., p. 10.

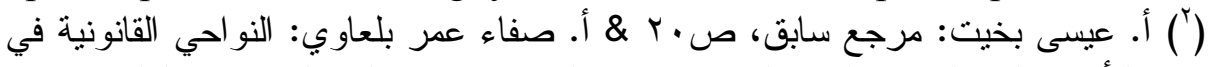

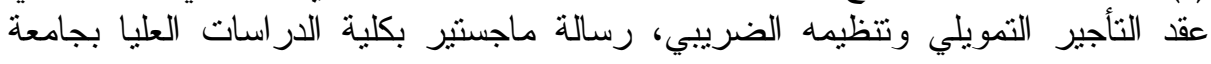

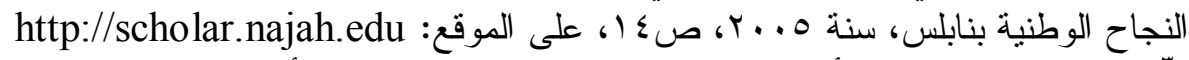

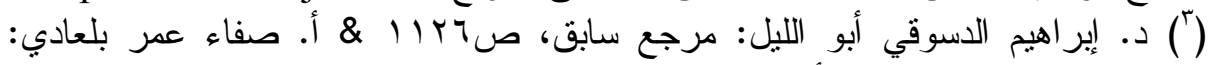

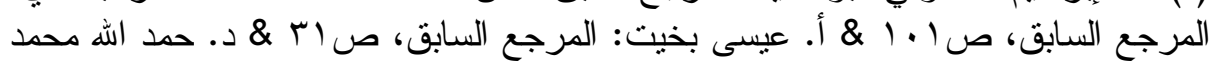

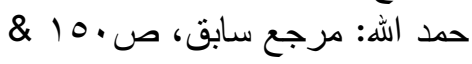

Philippe Rodier, op. cit., p. 95 \& Louis Payette, la location á long terme de matériels d' equipment et de véhicules routiers, Revue du barreau, tome 62, printemp, 2002, p. 19, sur le site, www.barreau.qc.ca

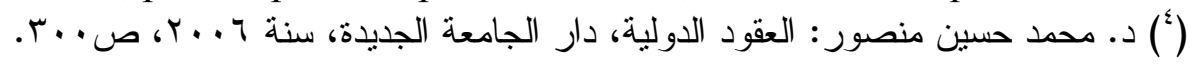

roo 
و غالباً ما يكون بنك أو مؤسسة مالية ويسمى بــالمؤجر المـــول للاســثــار (')loueur finançant l' investissment

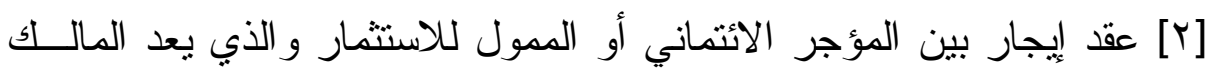

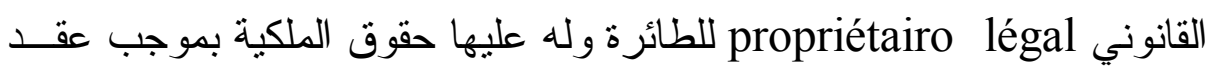

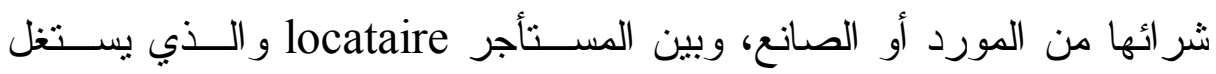

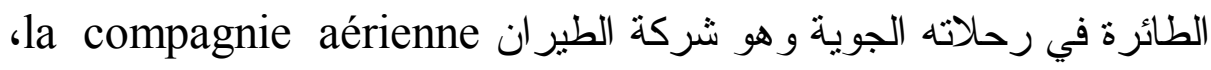

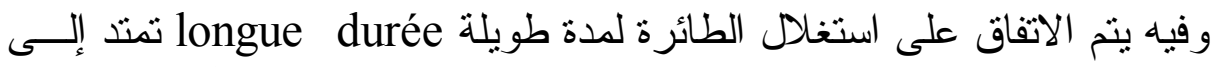

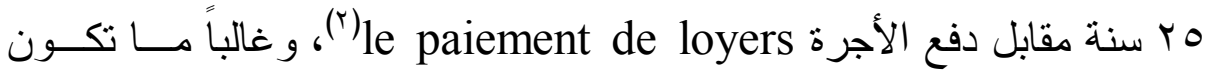

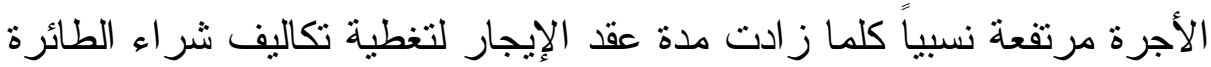

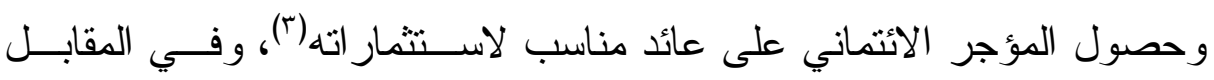

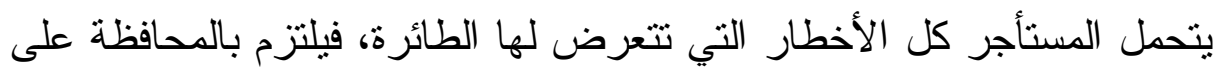

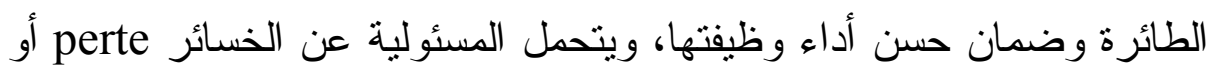

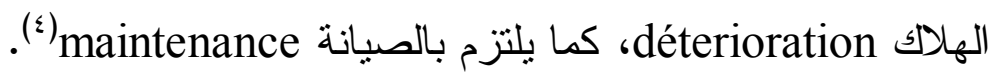

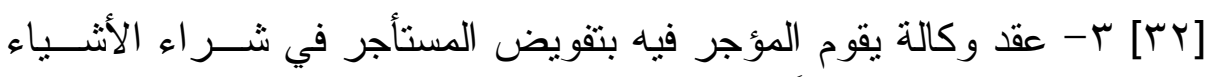

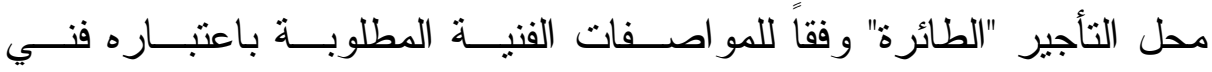

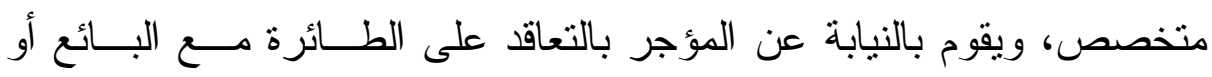

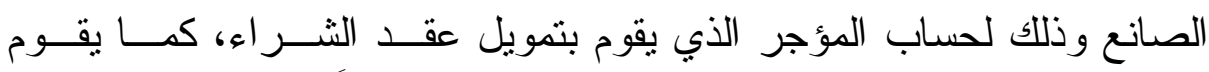

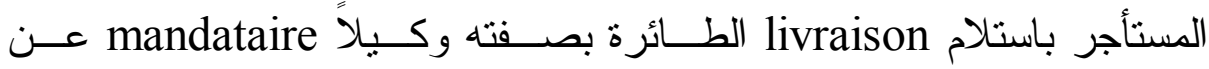
المؤجر (ن).

$\left.{ }^{1}\right)$ Philippe Rodier, op. cit., p.95 \& Jean - François Gervais, op. cit., p. 5

$\left({ }^{2}\right)$ Philippe Rodier, op. cit., p. 97 et p. 101 \& Jean - François Gervais, op. cit., p. 5.

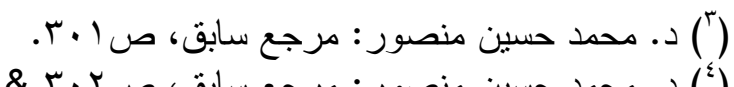

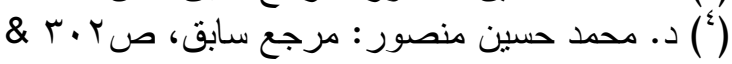

Philippe Rodier, op. cit., p. $101 \&$ Jean - François Gervais, op. cit., p.5.

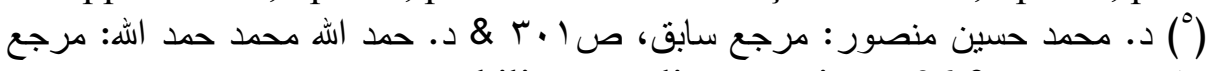

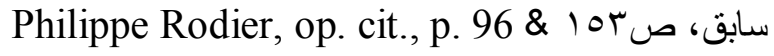


ع - و عد منفرد بالبيع أو إعادة الإيجار في نهاية مدة الإيجار يملكــهـ المــؤجر

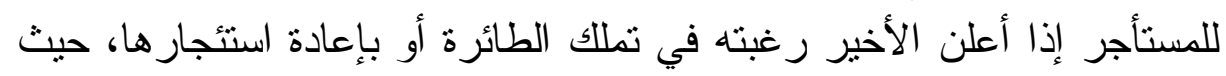

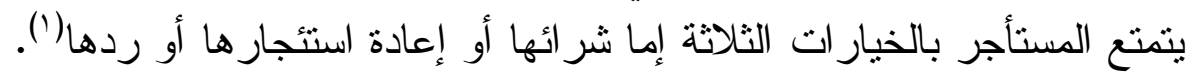

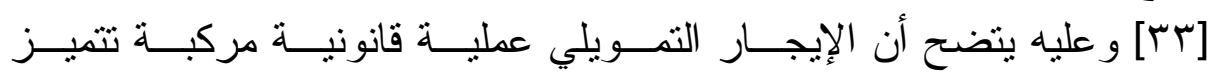
بالخصائص التالية: أ- عقد يحتوي على عقدين مرتبطين ببعضهما هما عقد إيجار بــين المــؤجر

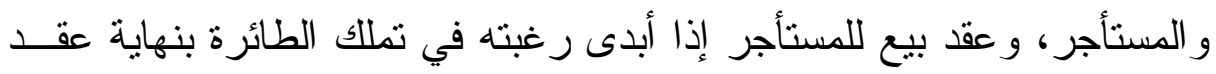

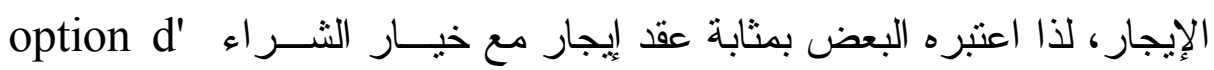
achat promesse unilatéralle

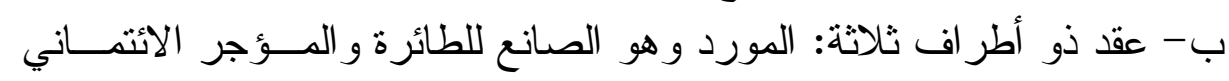

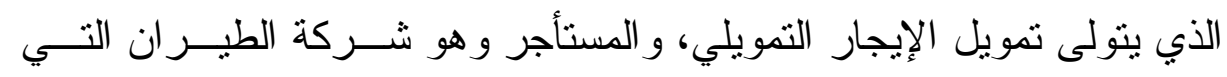
تز غب في استغلال الطائرة.

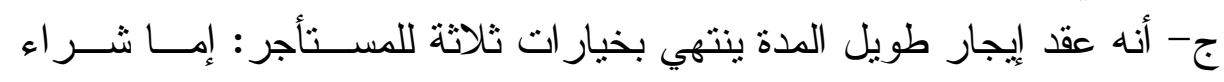

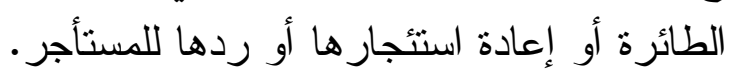

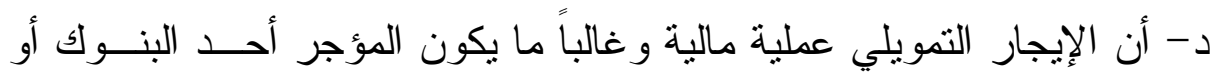

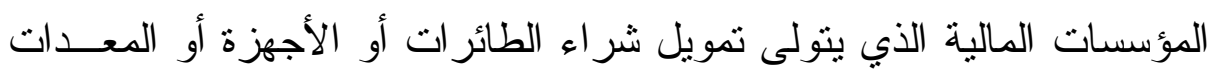

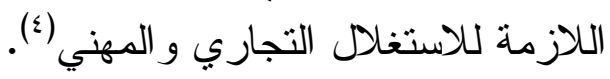

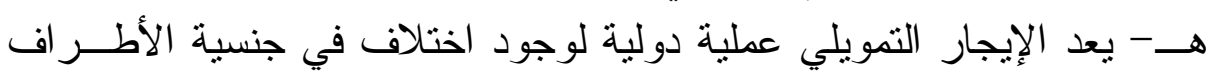

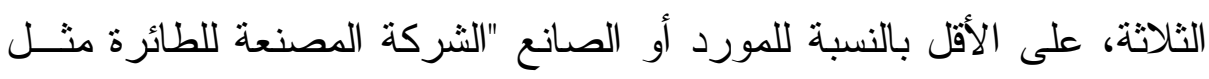
Airbus, Boeing, Avionneur

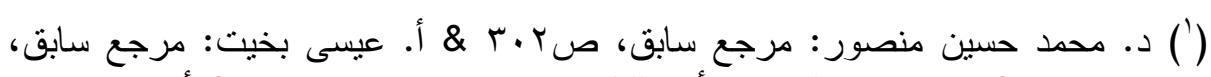

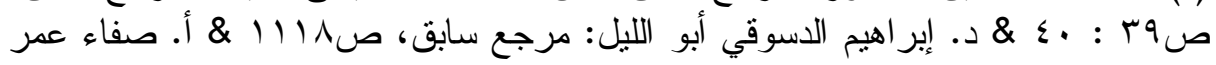

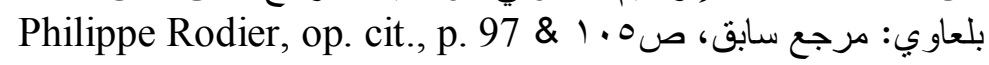
$\left({ }^{2}\right)$ Louis Payette, op. cit., pp. 31:32 \& Jean - François Gervais, op. cit., p.7.

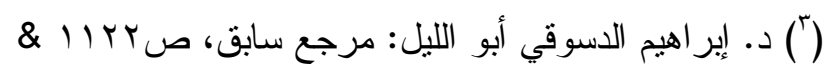
Florent Vigny, Timothée Bertrand, op. cit., p.9 \& Philippe Rodier, op. cit., p. 99 \& Gilles J. Guglielmi, le financent privé du développement local, p. 41, sur le site, www.u-picardie.fr

$$
\text { (l) د. دمعد حسين منصور : مرجع سابق، ص ا • r. }
$$


الدولي للقانون الخاص" يونيــدروا Unidroit (') و المســــى باتقــاق اوتـــاو ا في می Ottawa المبحث الثاني

\section{آثار عقود إيجار الطائر ات}

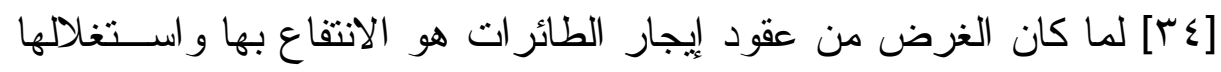

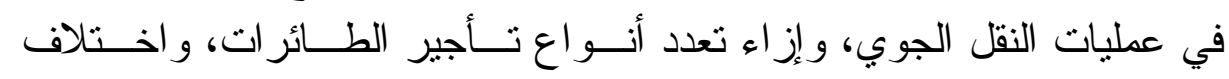

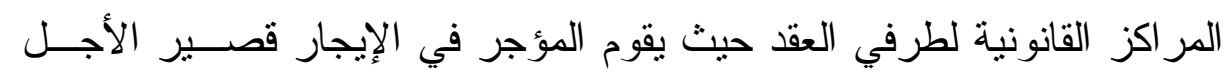

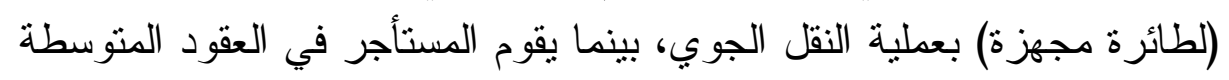

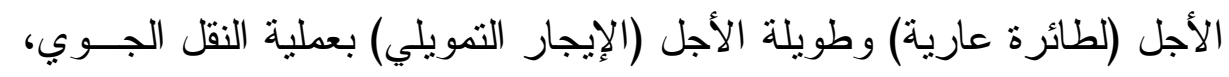

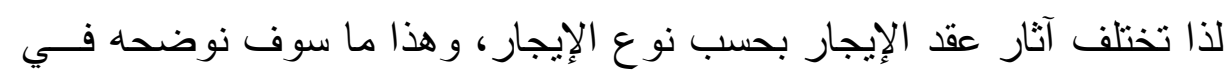

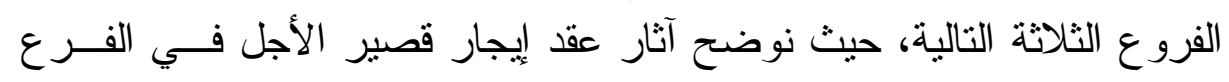

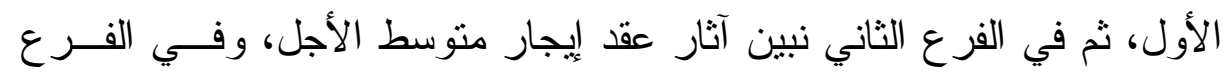

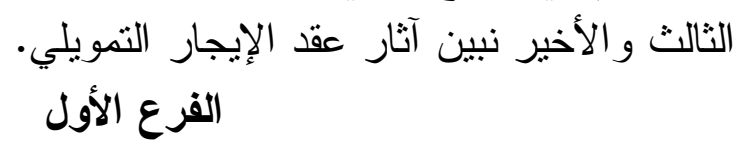

آثثار إيجار الطائرة مجزة الاول

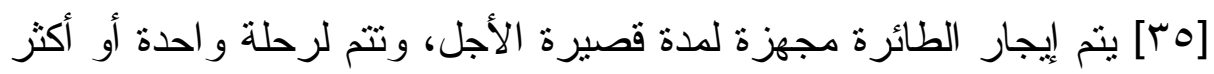

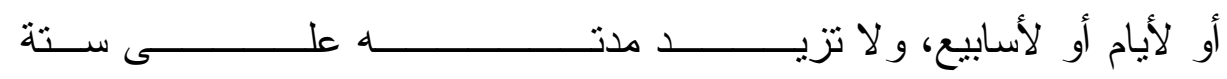

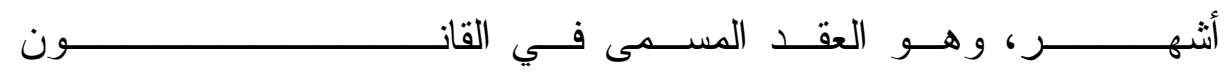

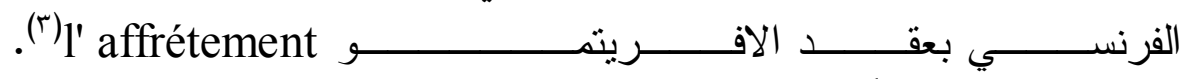
ويتم الافريتمو شاملاً طاقم الضيافة الجوية، لذا بسمى بالإيجار الثــامل

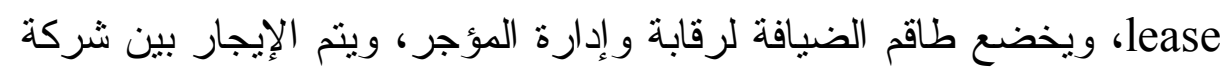

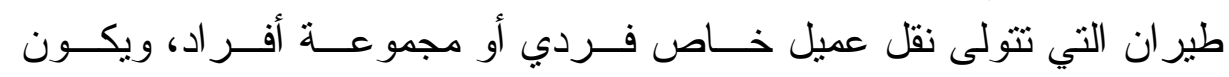

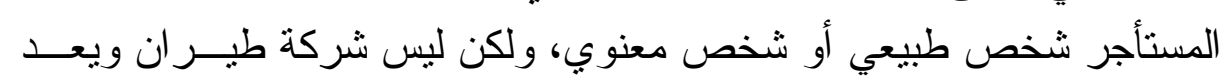

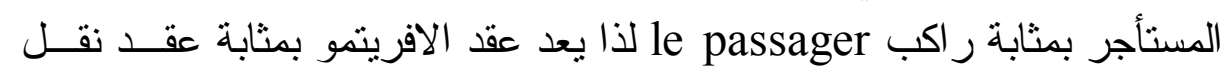

$\left(^{2}\right)$ Philippe Rodier, op. cit., p. 105.

Unification de droit privé اختصار اً لـ (')

(3) Philippe Rodier, op. cit., p. 144. 
جوي خاص(')، ويرتب هذا العقد التز امات على كل من المــؤجر و المسـتنأجر نوضحها في النقاط التالية.

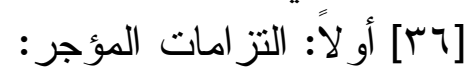

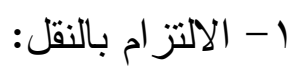

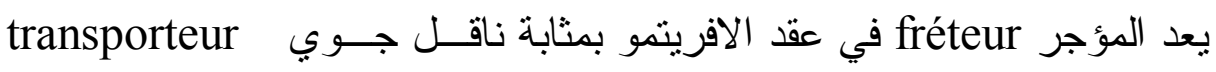

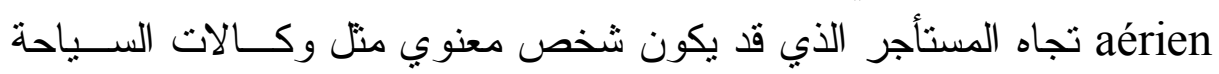

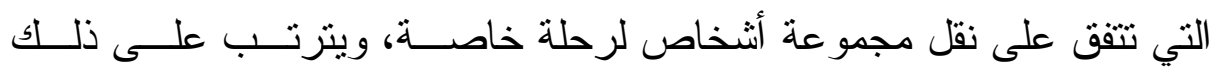

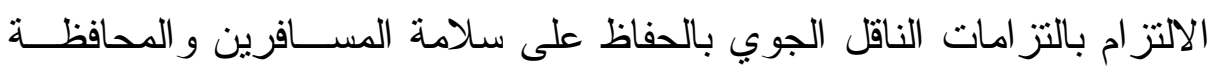

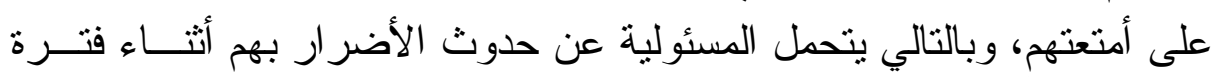

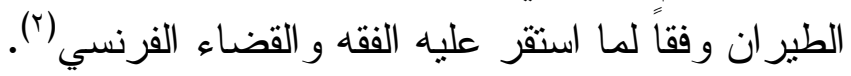
r- الالتز ام بإدارة طاقم الملاحة:

في هذا العقد يقوم المؤجر بتعيين طاقم الملاحة الجوية من طيارين و غيـــرهم

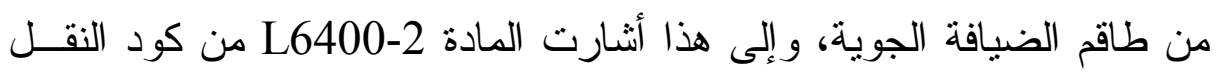

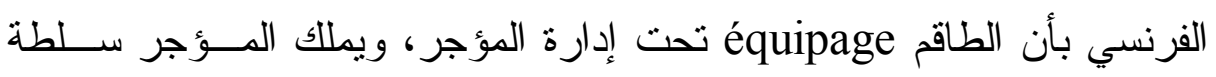

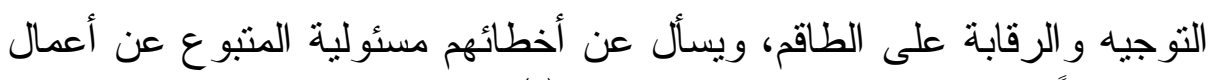

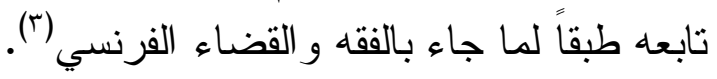
r- الالنز ام بالصيانة و التأمين على ولى الطائرة:

( ${ }^{1}$ Florent Vigny, Timothée Bertrand, op. cit., p. 10 \& Philippe Rodier, op. cit., p. 146 \& David Sprecher, vols affrétés et responsabilité: quel cadre juridique pour les agences de voyages?., le 27 Juillet 2014, sur le site, www.tourmag.com/vol

$\left(^{2}\right)$ Xavier Delpech, contrat d' affrètement aérien: responsabilité du fréteur, Dalloz actualité, le 15 Octobre 2012, sur le site, www.dallozactualite.fr \& David Sprecher, op. cit., \& Cass. Civ, 13 Mars 2013, N09-72962 \& Cass. Com, 2 Octobre 2012, N11-21362.

$\left({ }^{3}\right)$ Philippe Rodier, op.c it., p. 142 \& Xvier Delpech, op. cit., \& Cass. Com, 2 Octobre 2007, N06-14121 Cass. Civ, 4 Février 2016, N1429839 \& Cass. Civ, 11 Septembre 2014, N13-21459 \& Cass. Civ, 6 Juin 1990, N88-18991, les sentences sur le site, www.legifrance.gouv.fr 
يسمى عقد الافريتمو بالإيجار الثـامل wet lease، حيــث يتحمــل المــؤجر

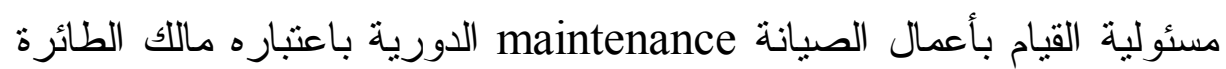

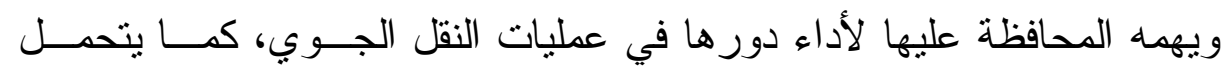

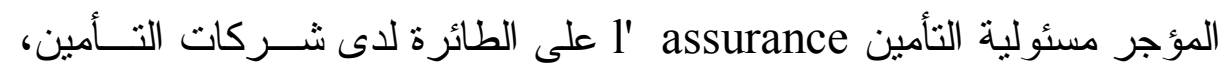

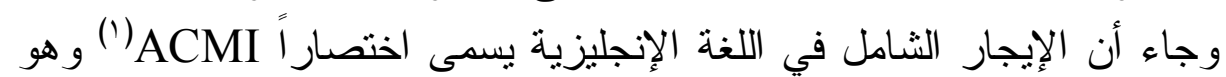
يشمل الصيانة و التأمين (r).

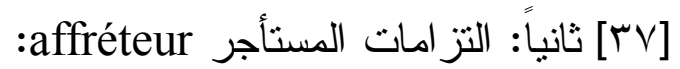

$$
\text { ا - دفع الأجرة: }
$$

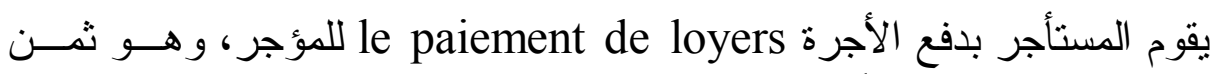

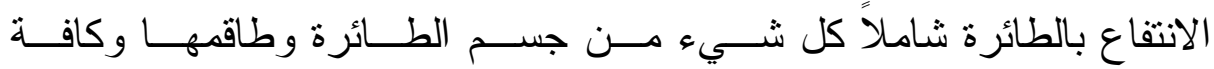

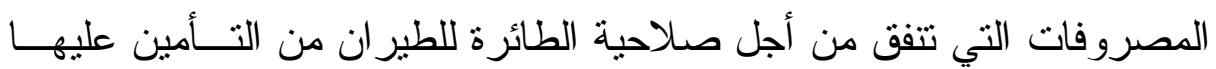

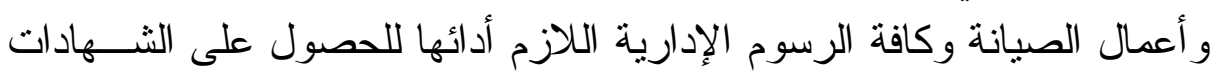

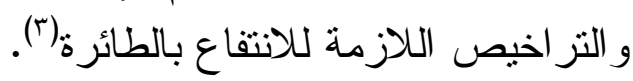
r- مر اعاة التز امات المسافرين:

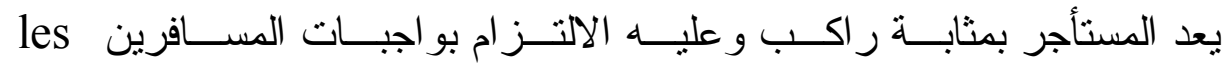
passagers

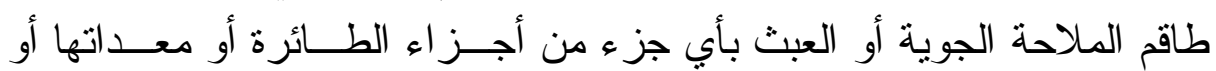

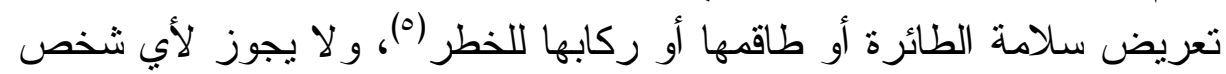

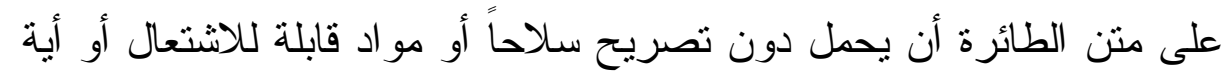

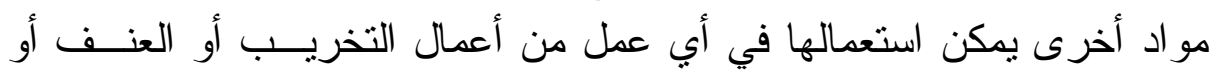

Aircraft Crew Maintenance Insurance : اختصار اً لـ (') (') $\left({ }^{2}\right)$ David Sprecher, op. cit., \& Philippe Rodier, op. cit., p. 155 \&

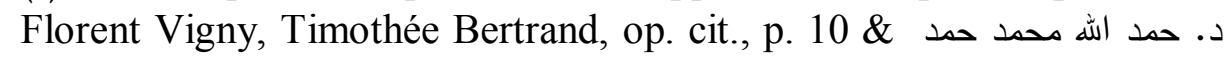

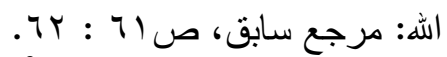

$\left(^{3}\right)$ Philippe Rodier, op. cit., p. 155 \&

$\left({ }^{4}\right)$ Philippe Rodier, op. cit., p. 146.

د. حمد الله محمد حمد الله: مرجع سابق، صبآ.

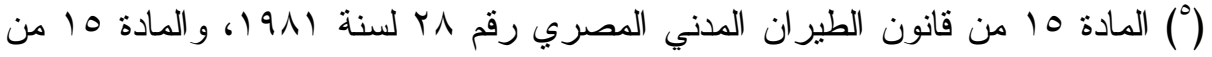

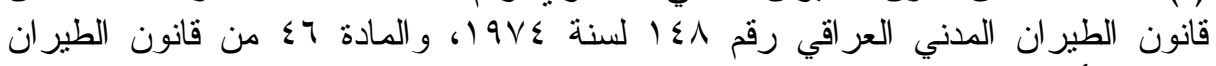

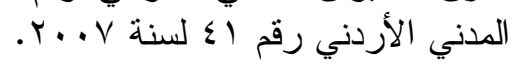


التهديد أثناء الرحلة(')، كما لا يجوز لأي شخص دخول غرفة فيادة الطائرة إلا

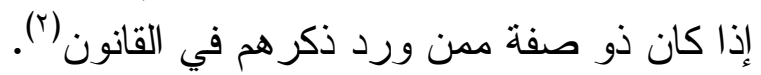
الفرع الثاني

\section{آثثار إيجار الطائرة عارية}

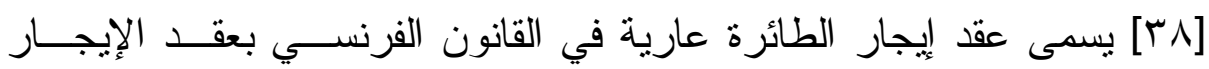

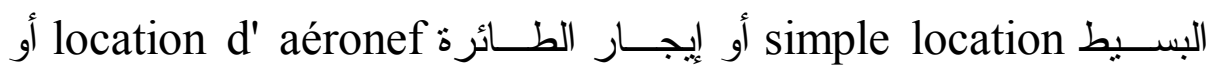
الإيجار الجاف dry lease لأن التعاقد يتم على جسم الطائرة فقط لذا يسـمى لئى بايجار الطائرة عارية coque nue، و عادة ما تكون مدة التعاقد لمدة منوسطة

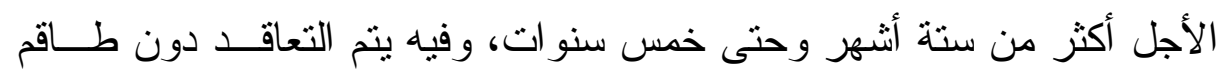

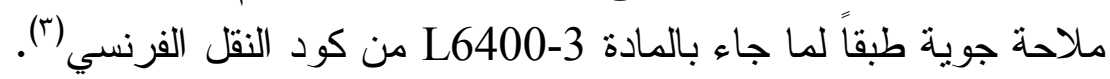

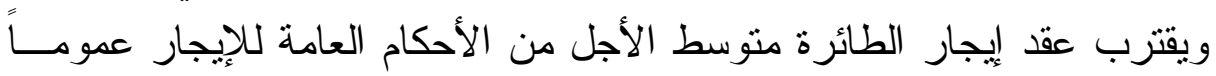

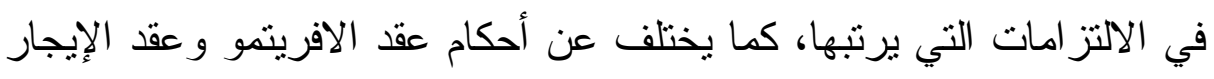

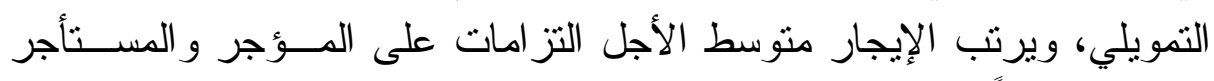
نوضحها نباعاً.

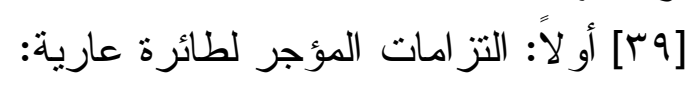
1- الالتز ام بتسليم الطائرة:

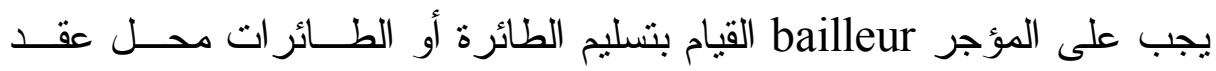

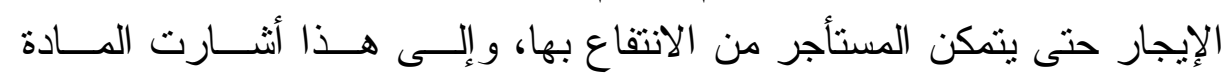

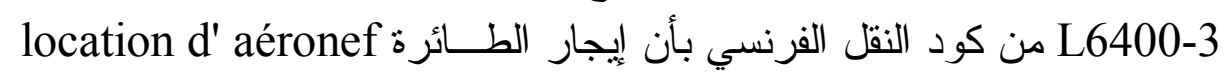

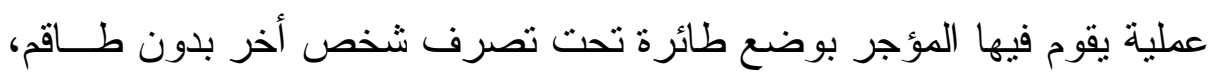
و الوضع تحت التصرف هو عملية التسليم.

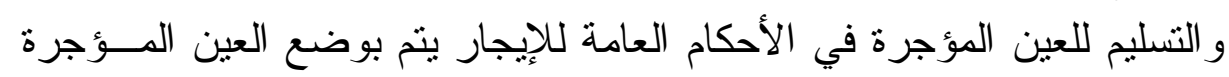

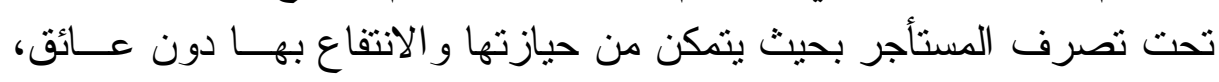

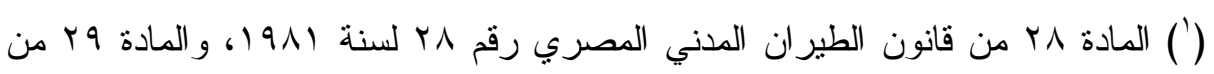

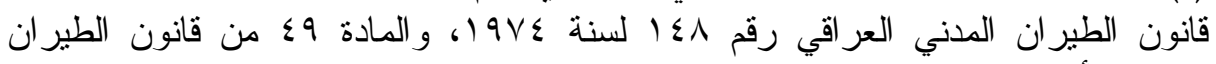

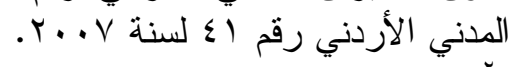

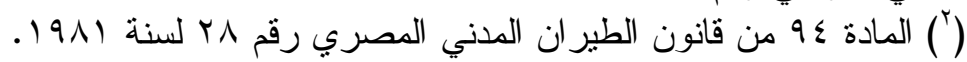
$\left(^{3}\right)$ Philippe Rodier, op. cit., p. 147:148 \& Florent Vigny, Timothée Bertrand, op. cit., p. 20. 


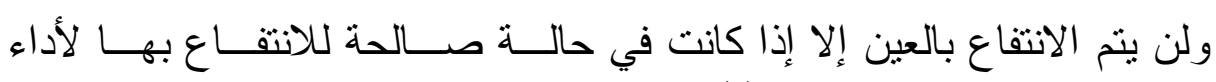
الغرض المقصود من إيجار ها('ال). لذا برتبط بتسليم الطائرة أن تكون بحالة صالحة هارل للطير ان حتى يتم الانتفاع بها،

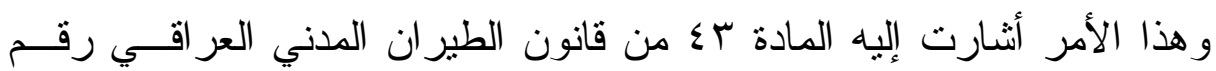

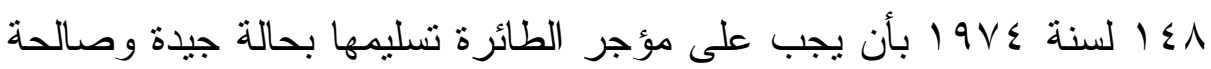

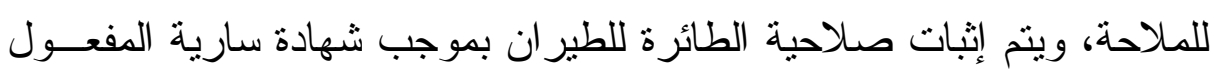
صادرة من الدولة المسجلة بها، وقد اثشترطت التشريعات العربية المقارنة عدة التهات شروط في الطائر ات التي تعمل من بينها وجود شهادة صلاحية سارية المفعول

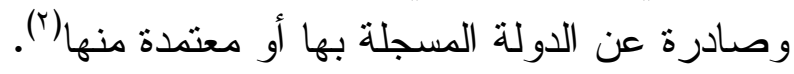

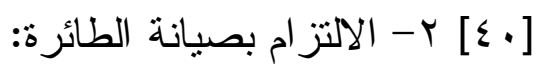

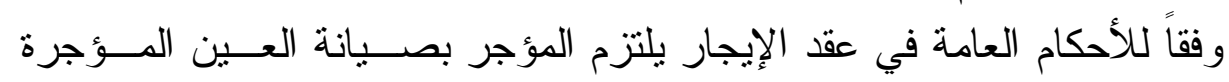

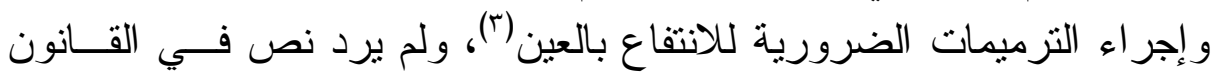

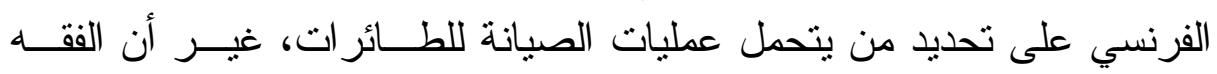

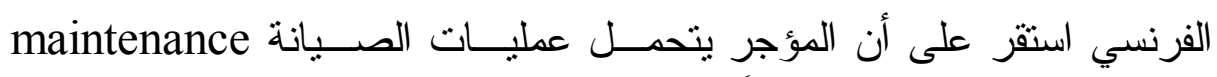
باعتباره المالك و الأكثر حرصاً على أعمال الصيانة للمحافظة على رلى رأس ماله، كما جاء أن الإيجار الجاف dry lease قد يكون على طائرة بالصيانة أو بدون صيانة(£) كماء

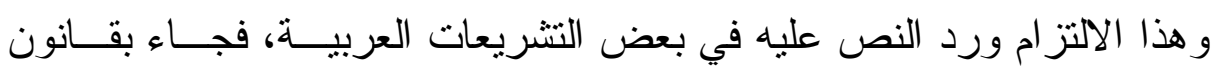

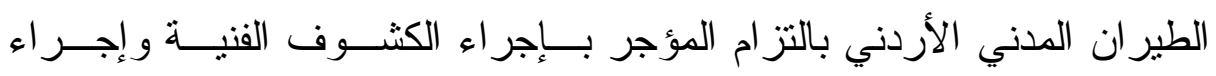

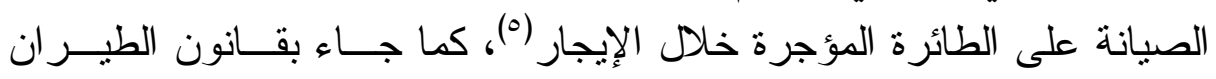

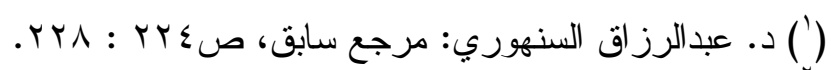

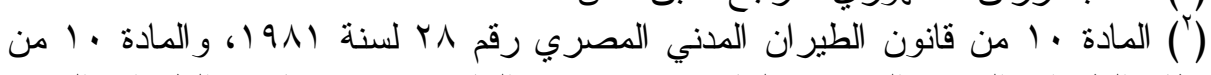

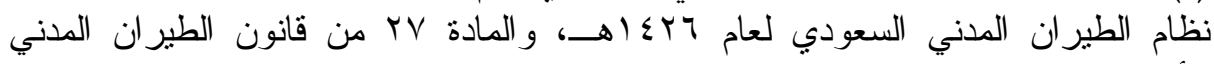

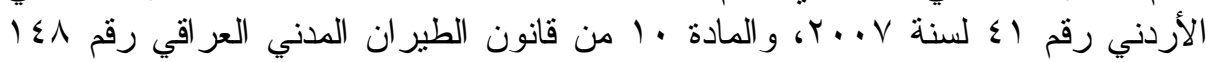

(4) David Sprecher, op. cit., \& Pilippe Rodier, op. cit., p. 155.

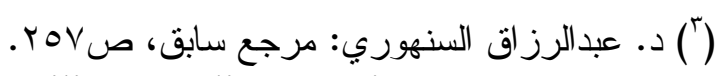

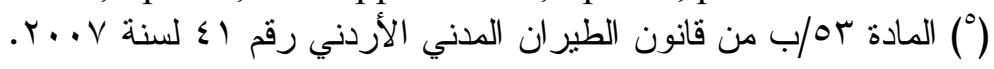


المدني العر اقي أن على المؤجر القيام بصيانة الطائرة و إجر اء الكثوف الفنيــة

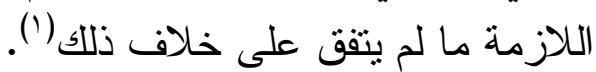

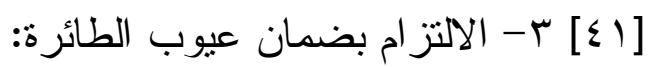

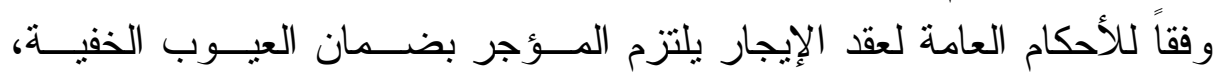

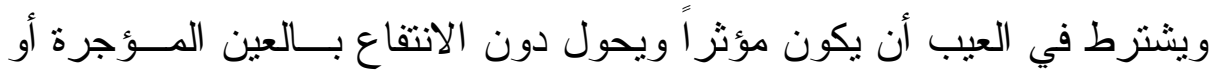

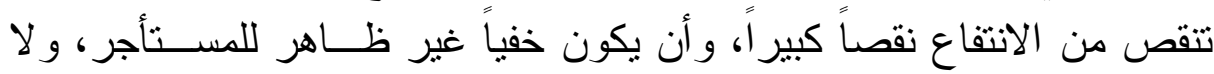

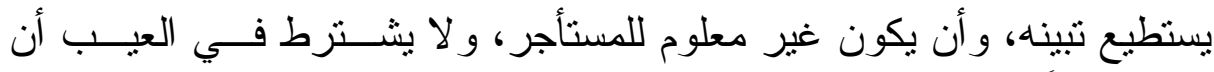
يكون قديماً فالمؤجر يضمن العيب الذي يظهر بعد التسليم (r).

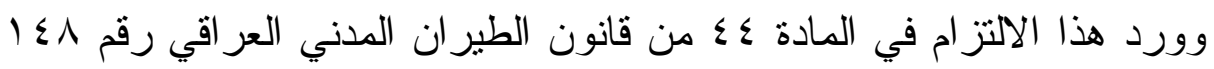

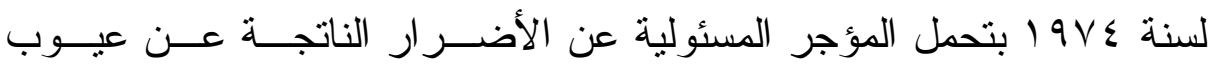

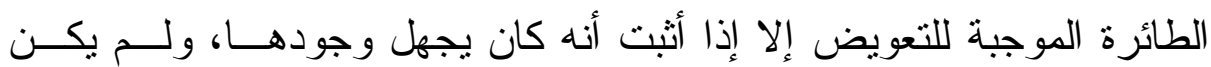

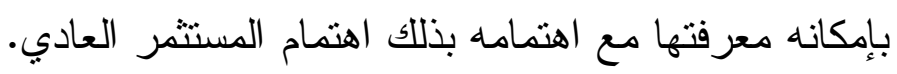
ع - الالتز ام بتسجيل عقد إيجار الطائرة:

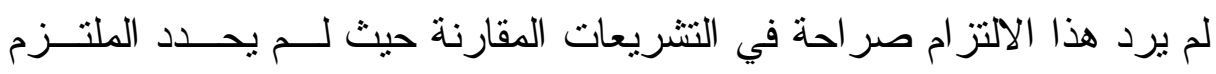

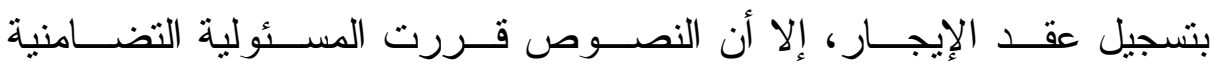
solidarité

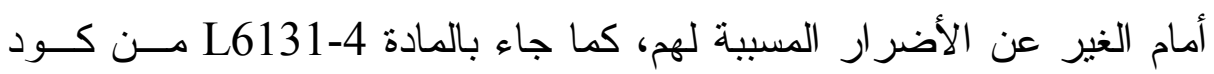

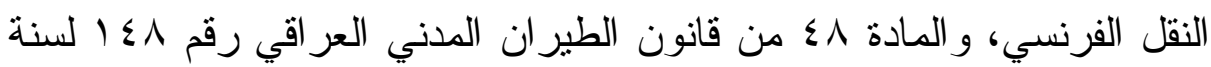
ع 9 1، و أضافت النصوص السابقة بتحمل المستأجر وحده المسئولية حال قيد فئ

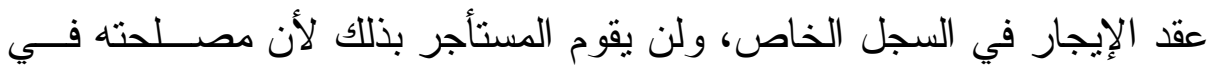

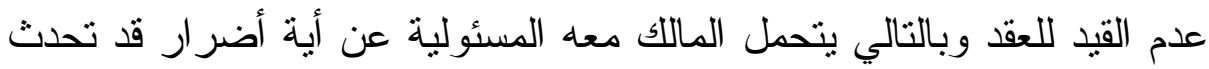

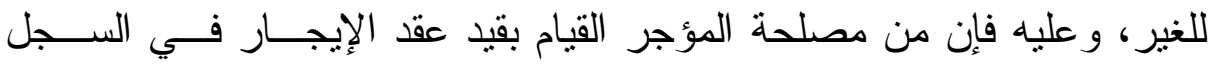

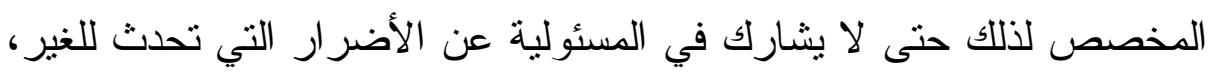

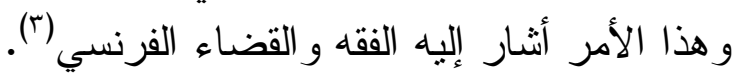

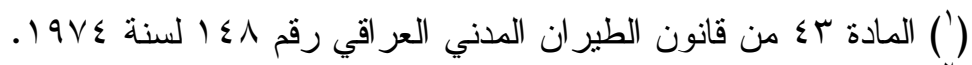
(')

(3) Philippe Rodier, op. cit., p. 149 \& Florent Vigny, Timothée Bertrand, op. cit., p. 18 \& Michel Asencio, op. cit., p. 9 \& Cass. Civ, 12 Mai 2004, N01-14259 et N01-14931 \& Cass. Civ, 9 Octobre 1979, N78-12503, le sentences sur le site, www.legifrance.gouv.fr 
[ [؟ ثانياً: التز امات المستأجر لطائرة عارية: يلتزم المستأجر locataire للطائرة في العقد متوسط الأجل بسائر الالتز امــات

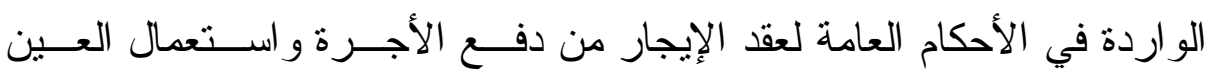
المؤجرة بحسب ما أعدت له و المحافظة عليها وردها في نهاية عقد الإيجار (1)، وهذا ما سوف نوضحه تفصيلاً في النقاط التالية. ا - دفع الأجرة: يتم الانتفاع بالطائرة و استغلالها في النقل الجوي مقابل أجـرة

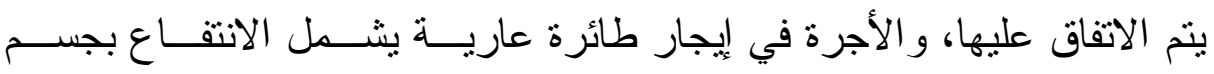
الطائرة فقط، على أن يتولى المستأجر التعاقد مع أطقم الملاحة الجوينة، ويــتم

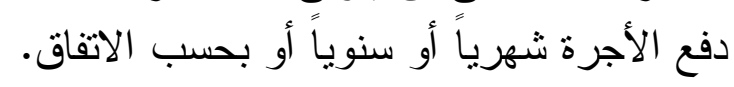
ץ- الاستغلال المناسب للطائرة: فيمتتع على المستأجر الإفر اط في اســتعمال الطائرة حتى لا بؤدي إلى استهالك الطائرة في مدى قصير ، ويعرضها بشــــ

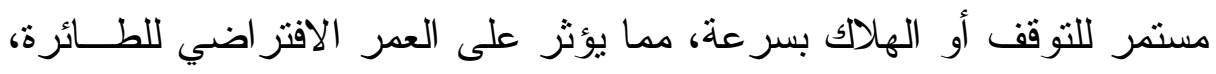

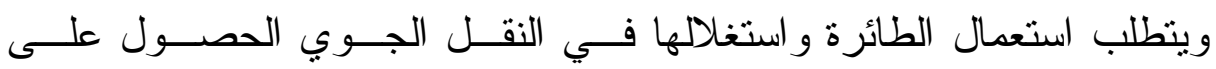
التز اخيص و إنهاء الإجراءات الإدارية المتطلبة لتشغيل الطائرة ودفع ما بتطلبه ذللك من رسوم ونفقات، ويحتفظ المؤجر بحق التفتيش الدوري علــى الطــائرة للتأكد من تتفيذ المستأجر بحسن الاستعمال فإذا تبين أن المستأجر أخل بالتز امه ونه

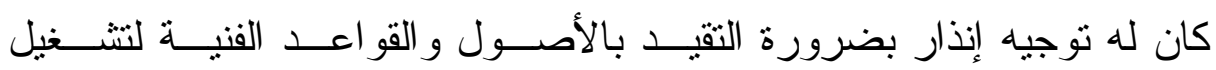
الطائر ات، أو طلب الفسخ مع التعويض إن كان لله مقتضى (r)، وهذا الالتـز ام

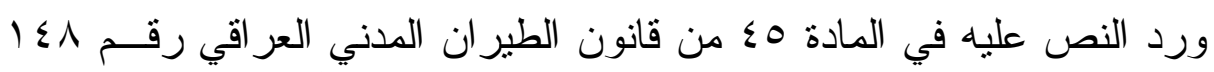

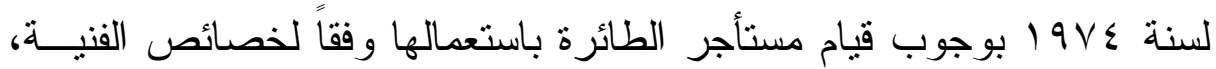

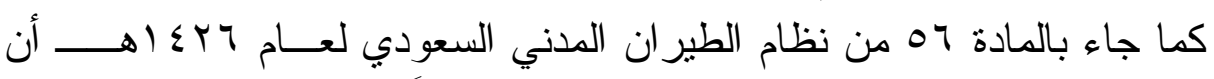
الحقوق التي تزد على الطائرات حق الاستعمال وفقاً لعقد إيجار متفق عليه.

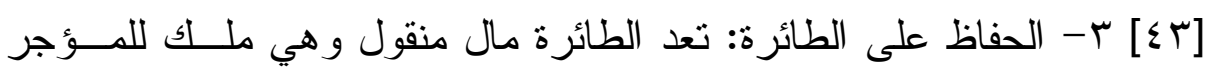

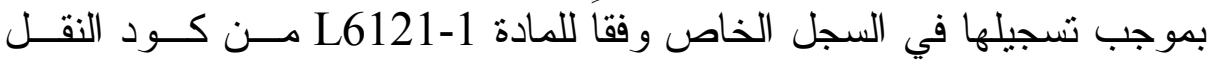
الفرنسي، ونتقل حيازتها إلى المستأجر بموجب عقد الإيجار ، وحيازة الطــائرة

$$
\text { (') د. د. عبدالرزاق السنهوري: مرجع سابق، ص الجآ ـ وما بعدها. }
$$

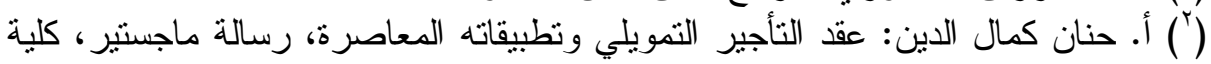

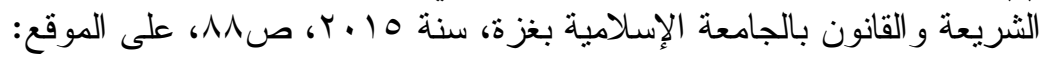
library-iugaza.edu.ps/thesis 


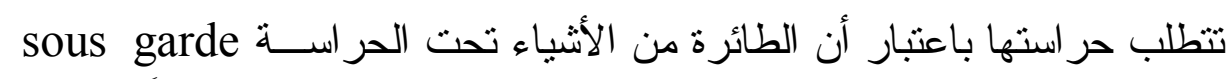

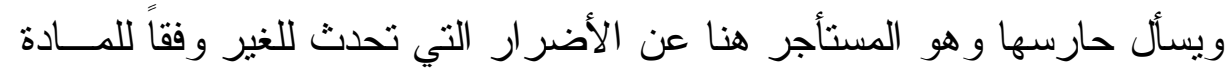

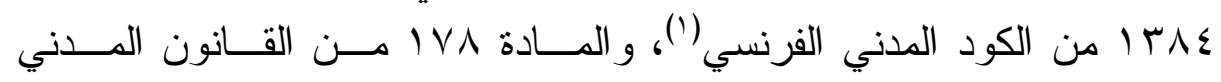

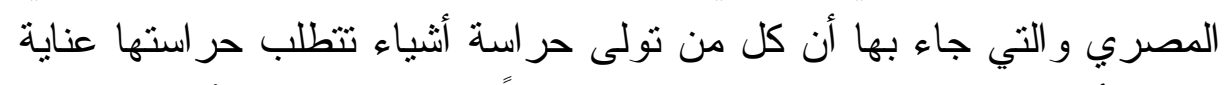

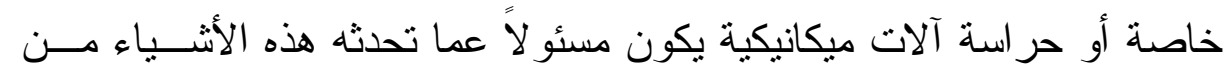

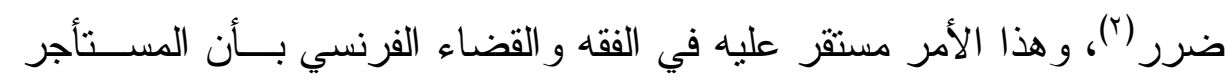

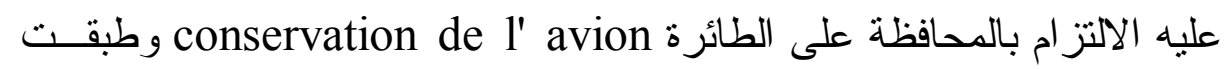

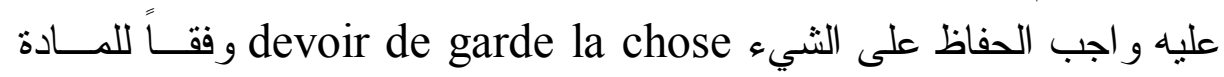

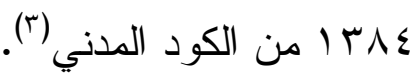

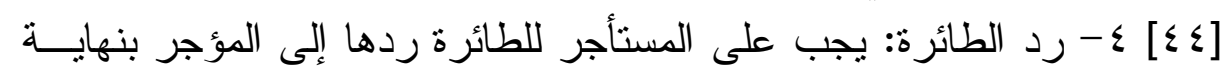

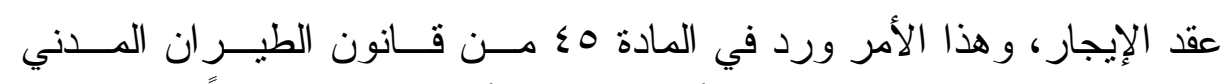

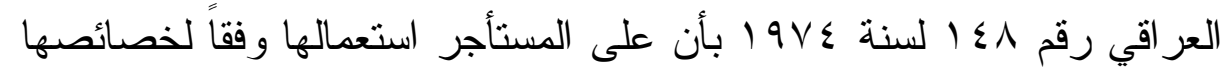

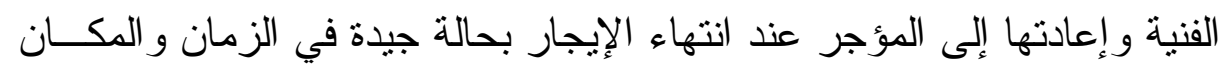
المتفق عليهما.

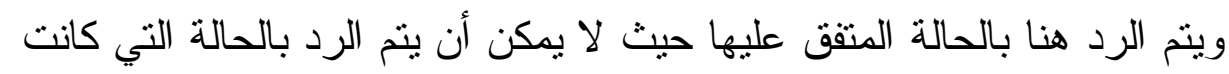

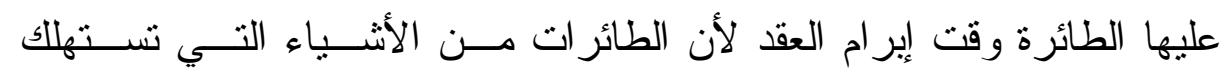

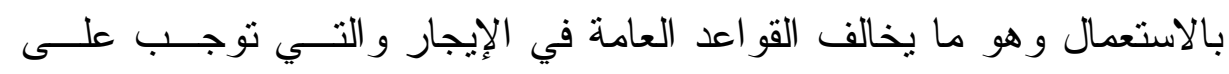

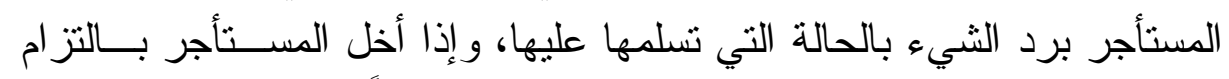

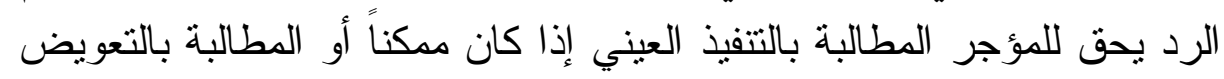

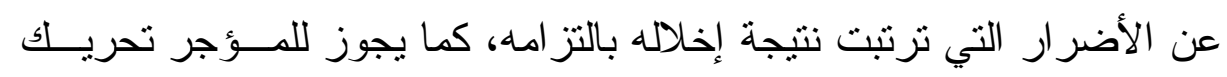

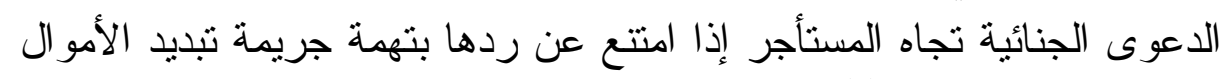

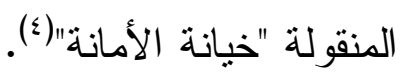

(1) Art. 1384 du code civil, modifié par loi n2002-305 du 4 Mars 2002.

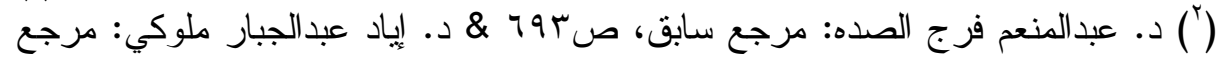
$\left({ }^{3}\right)$ Cass. Civ, 15 Mars 1989, N87-17287 \& Cass. Civ, 26 Février 1970, N69-10185 \& Cass. Civ, 27 Février 2007, N03-16083 \& Cass. Civ, 20 Juin 1973, N72-10788 \& Philippe Rodier, op. cit., p. 101.

$$
\text { (צ) أ. حنان كمال الدين: مرجع سابق، ص و } 9 .
$$




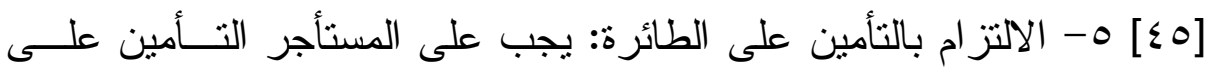

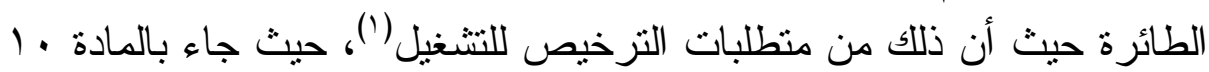

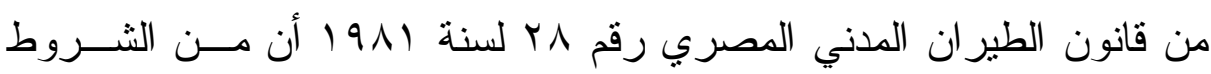

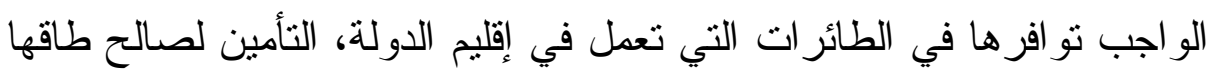

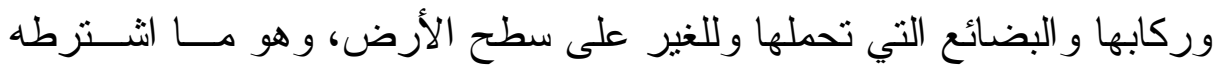

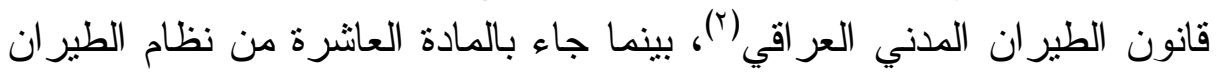

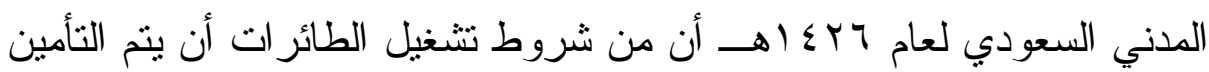

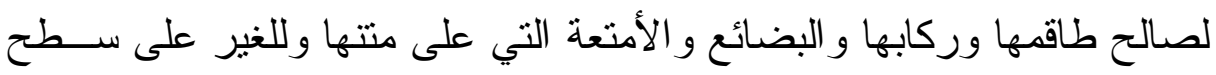

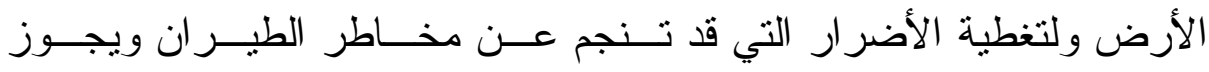

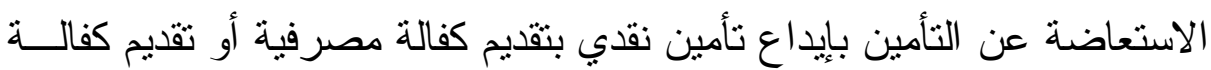

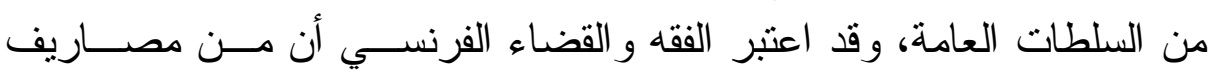

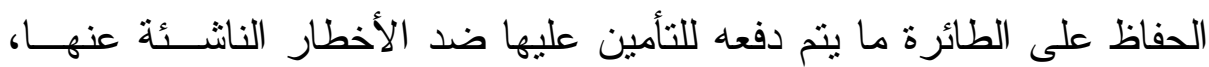

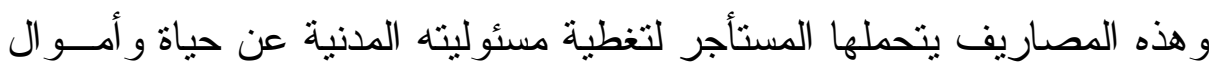

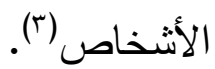

\section{الفرع الثالث \\ آثثار الإيجار التمويلي للطائرة}

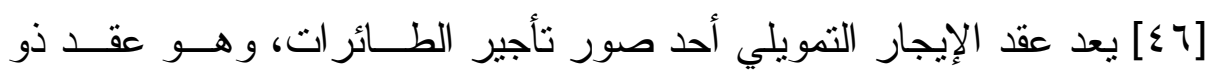

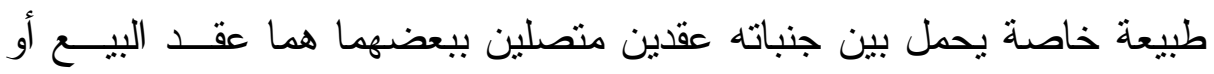

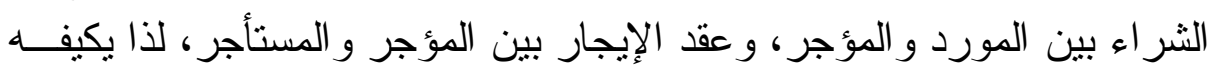

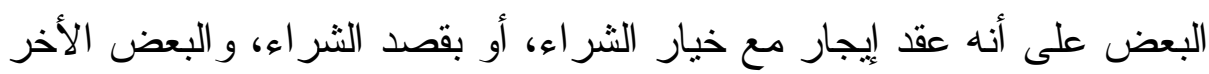

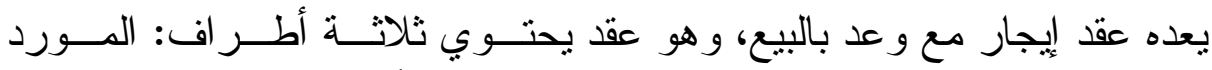
و المؤجر و المستأجر، ويرتب العقد التز امات على كلاً منهم نوضحها في النقاط

[ [ أو لاً: التز امات المورد le fournisseur أو الصانع avionneur:

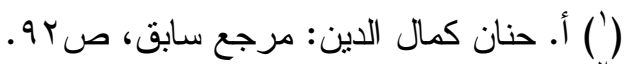

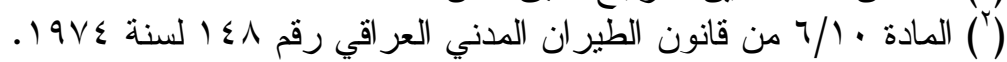

$\left(^{3}\right)$ Eric Roig, Assurance et location: obligations et garanties, Février 2016, sur le site, droit-finances.commentcamarche.net \& Cass. Civ, 17 Février 1981, N79-14935, sur le site, www.legifrance.gouv.fr 
المورد le fournisseur هو الثخص الذي ينولى توريد الطائرة محل الإيجار

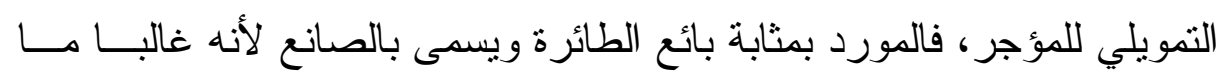

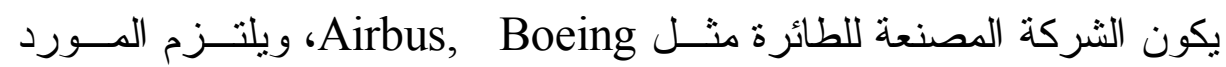

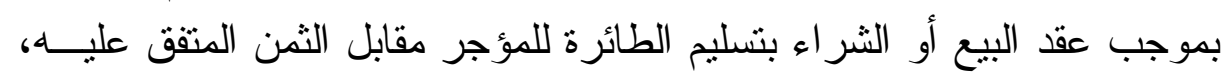

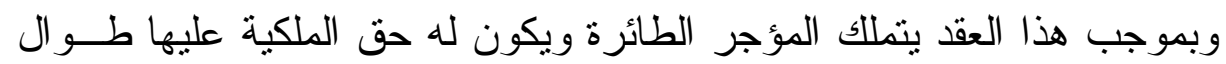
فترة الإيجار (').

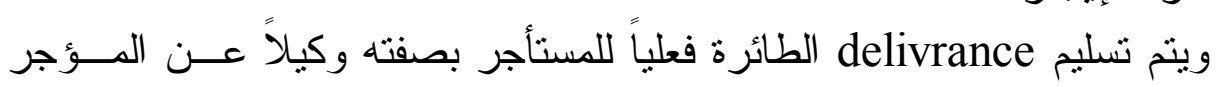

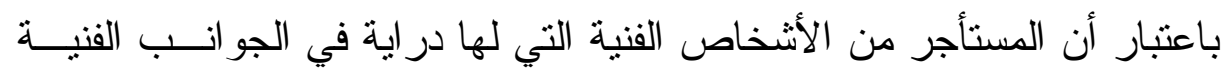

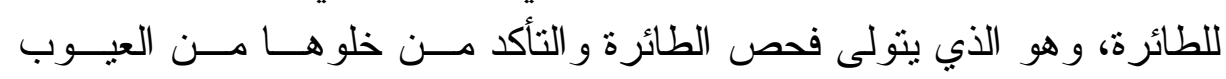

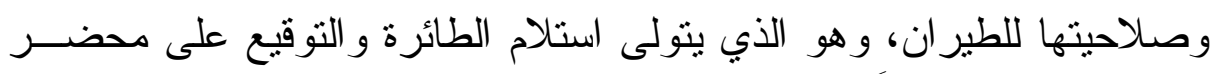

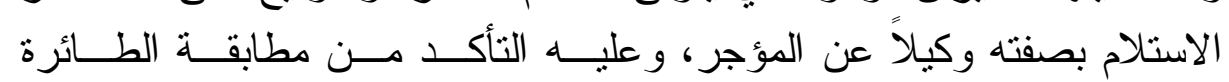

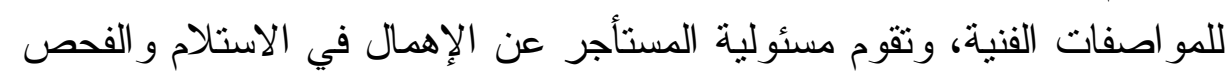

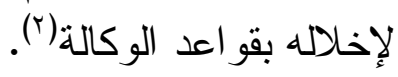

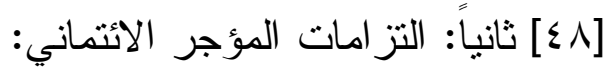
يعد المؤجر مالك الطائرة و الذي يتولى الألى عملية تمويل التأجير التمويلي لذا يطلق

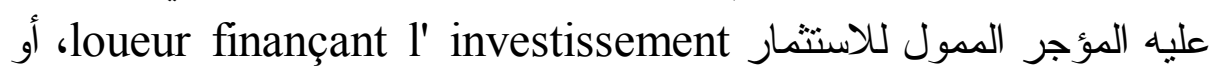

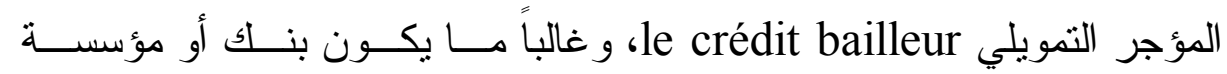
مالية(r)، ويلتزم المؤجر بالالتز امات التالية:

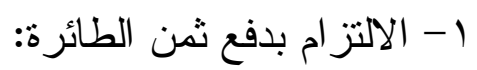

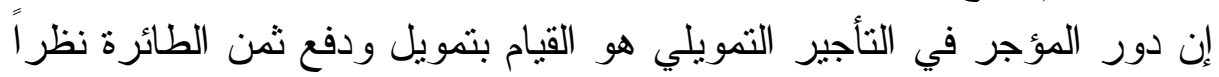

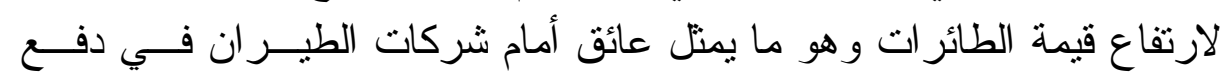

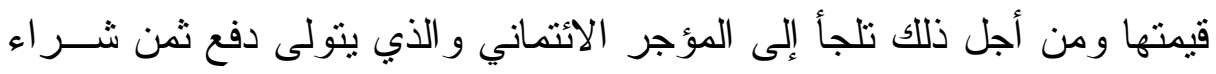

\& (') أ. صفاء عمر بلعاوي: مرجع سابق، صو (') Gilles J. Guglielmi, op. cit., \& Jean - François Gervais, op. cit., pp. 4:6 \& Philippe Rodier, op. cit., p. 95.

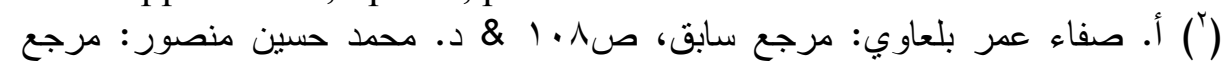

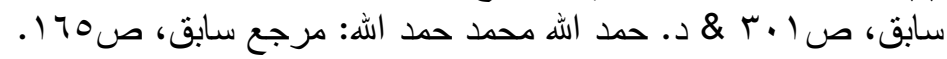
Jean - François Gervais, op. cit., p. 6 \& Philippe Rodier, op. cit., p. 101. $\left({ }^{3}\right)$ Jean François Gervais, op. cit., p. 5 \& Philippe Rodier, op. cit., p.95. 


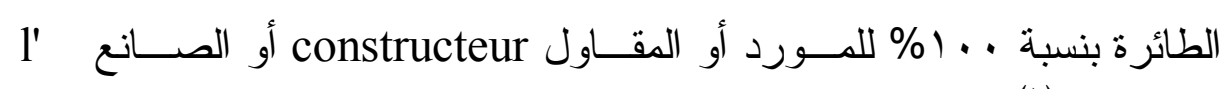
(')avioneur

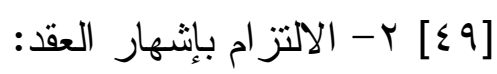
يتميز عقد التأجير التمويلي عن عقد إيجار الأشياء بالتز ام المــؤجر بــالإعلان obligation de publicité

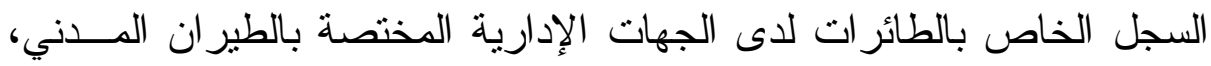

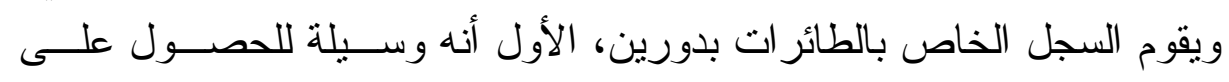

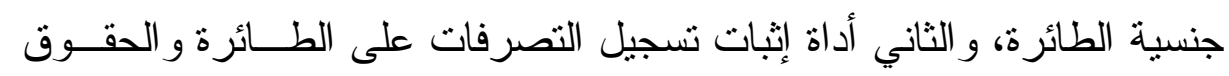

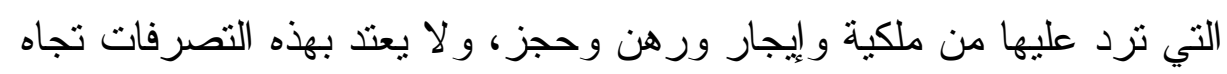
الغير إلا بعد القيد (ז).

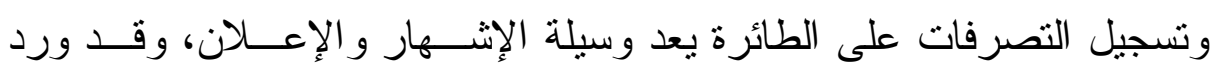

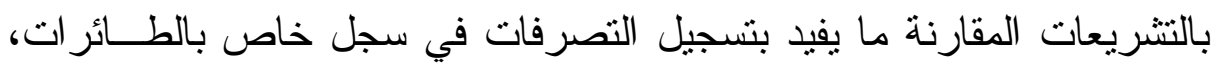

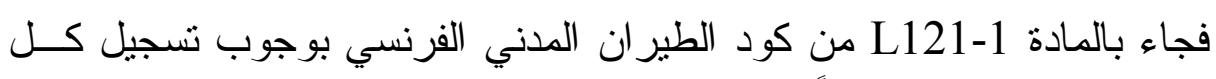

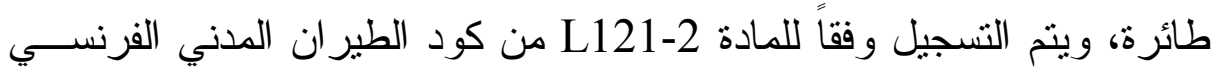

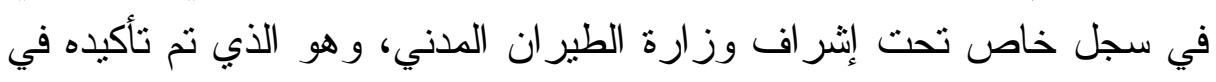

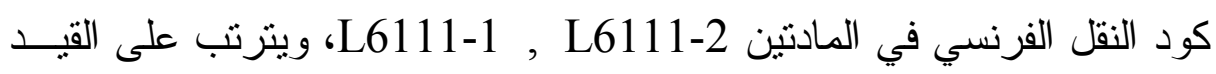
بالسجل حصول الطائرة على الجنسية الفرنسية.

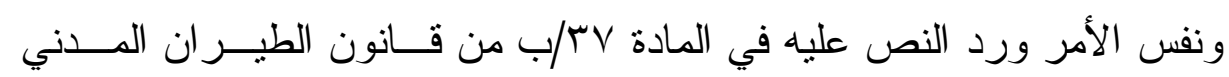

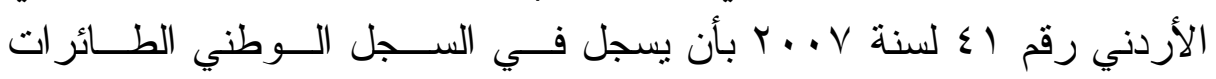

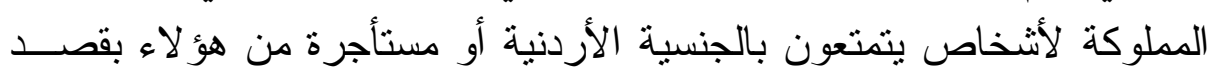

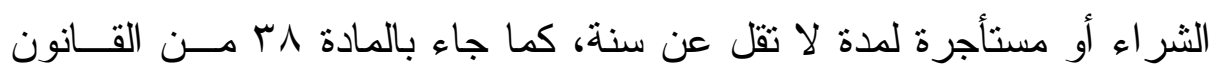

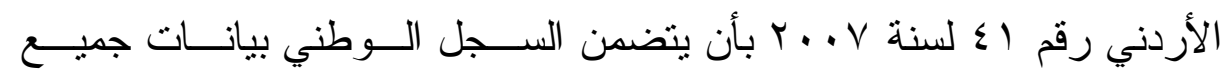

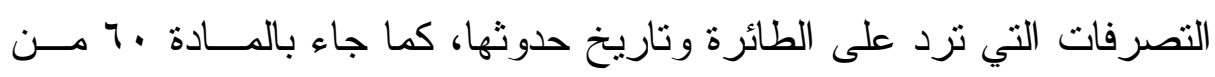

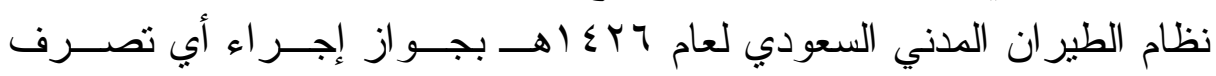

( $\left.{ }^{1}\right)$ Philippe Rodier, op. cit., p. 106 \& Jean - François Gervais, op. cit., p. 6 .

$\left(^{2}\right)$ Philippe Rodier, op. cit., p. 102.

(3) Philippe Rodier, op. cit., pp. 84:85 \& Florent Vigny, Timothée Bertrand, op. cit., p. 3 et pp. 44:16 \&

د. حمد الله محمد حمد الله: مرجع سابق، ص. V V . 
قانوني على أية طائرة وطنية لأي شخص بالبيع أو الإيجار أو الـــرهن أو أي ألـي

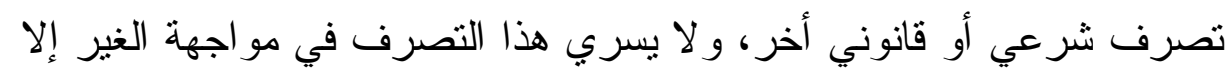
بعد قيده في السجل.

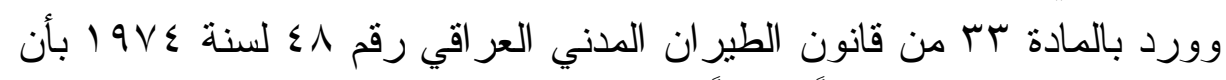

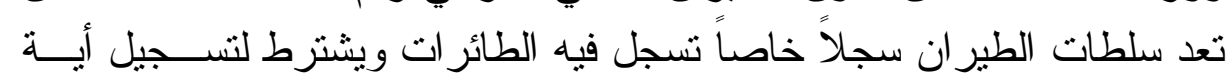

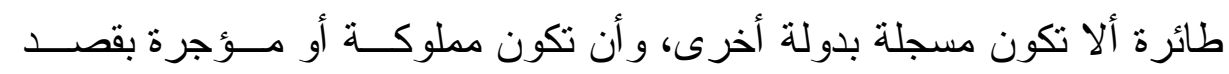

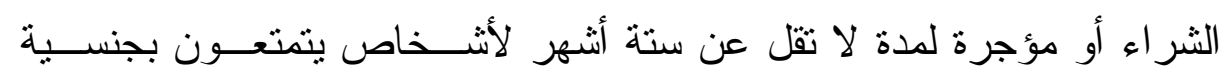

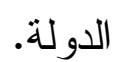

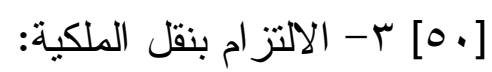

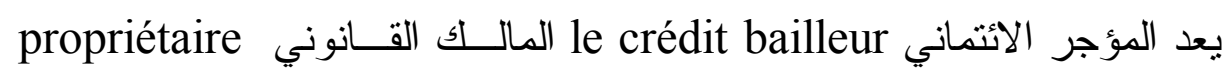

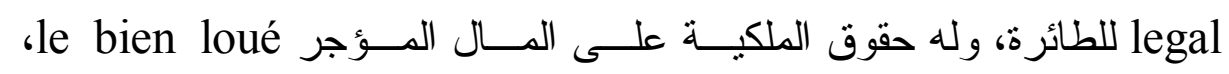

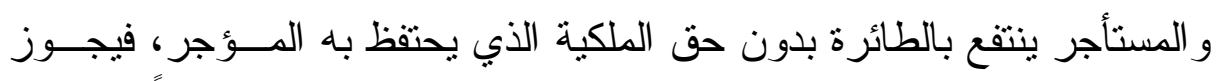

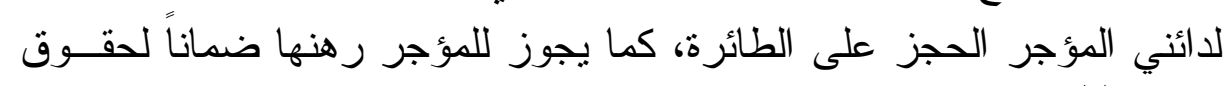

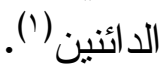

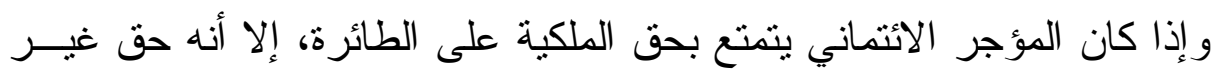

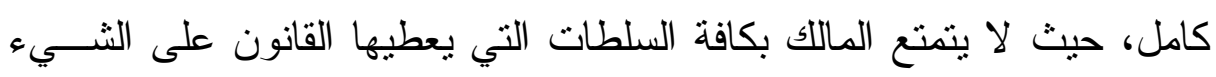

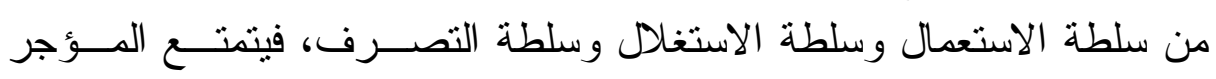

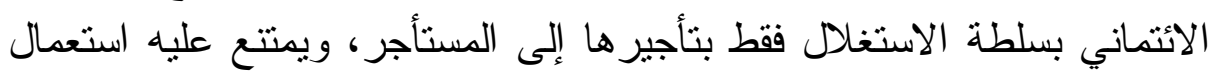

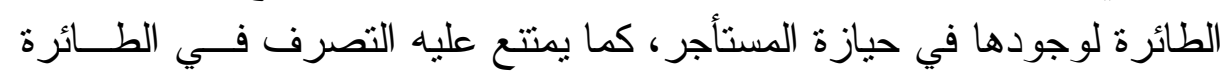

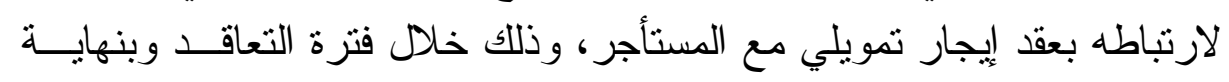

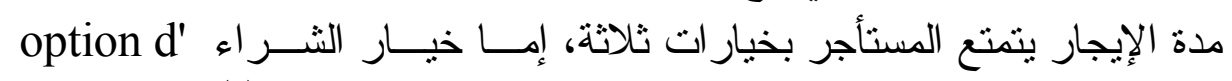

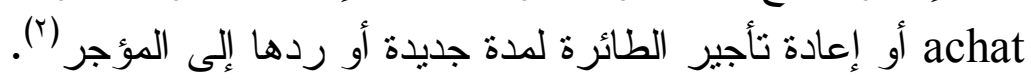

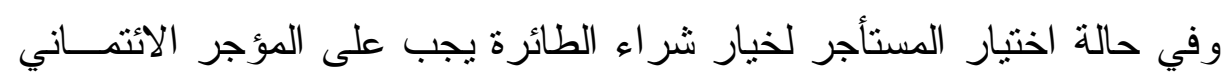

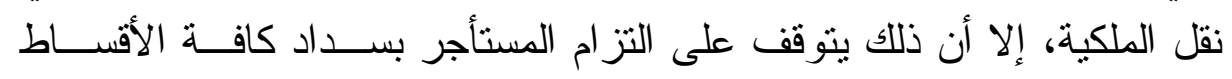

(') Philippe Rodier, op. cit., p. 101 \& Jean - François Gervais, op. cit., pp. 4:5.

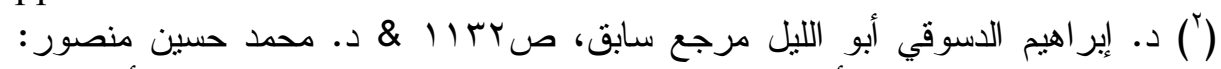

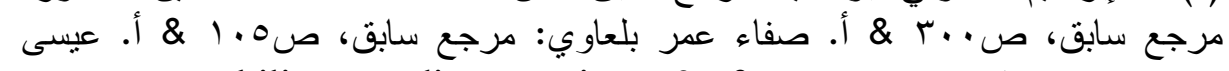

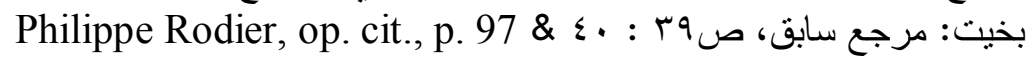


المتفق عليها في الإيجار ، وسداد كامل الثمن وفقاً للقيمة المحددة في العقد وهو

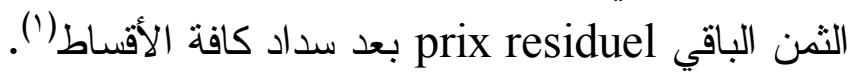

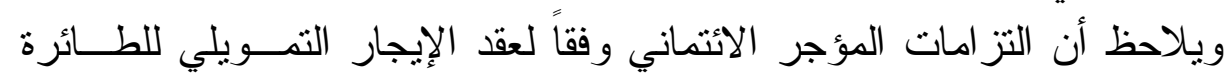

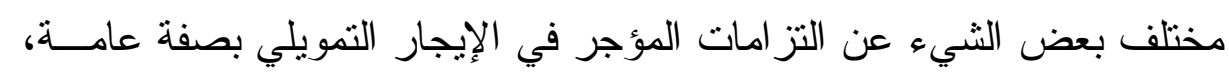

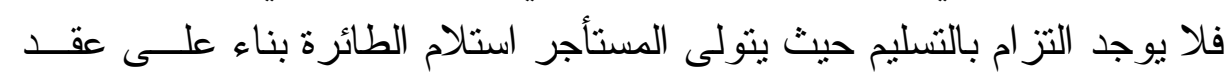

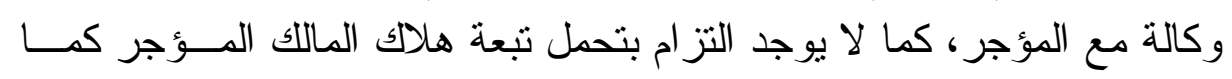

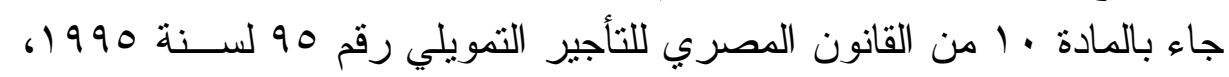

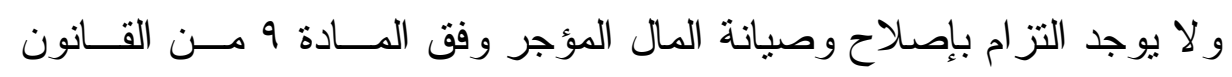

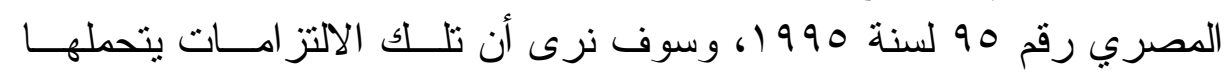
المستأجر للطائرة في الإيجار التمويلي، وذللك على خلاف ما جاء باء بالتز امسات التهات

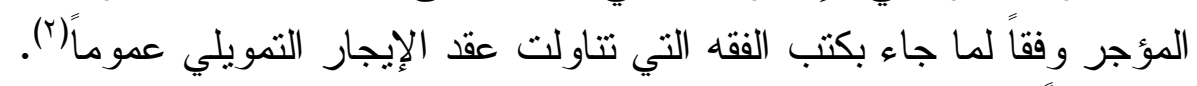

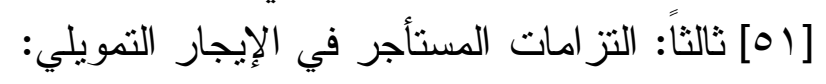

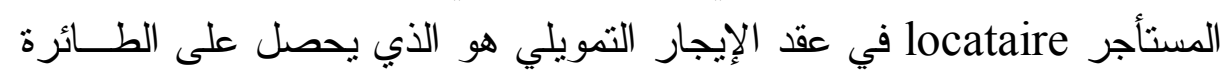

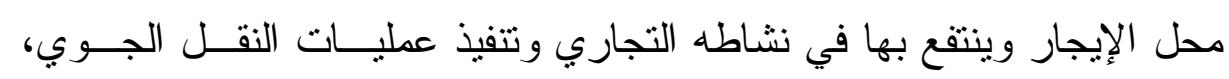

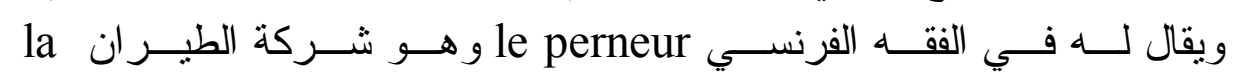
compagnie aérienne

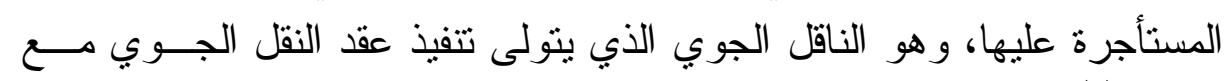

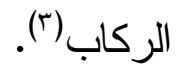

ونظر اً لأن المستأجر أو المنتفع utilisateur يتولى استلام الطائرة من المورد

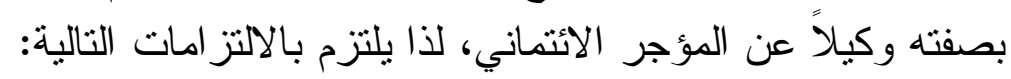

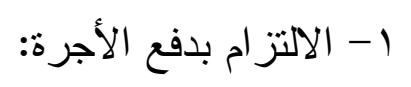

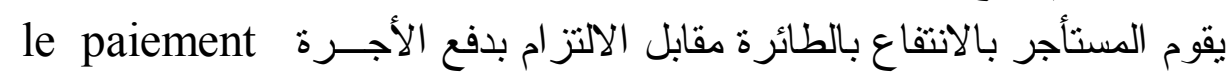
de loyers

$\left({ }^{1}\right)$ Florent Vigny, timothée Bertrand, op. cit., p. 9 \& Philippe Rodier, op. cit., p. 100 \& Jean - François Gervais, op. cit., p. 7.

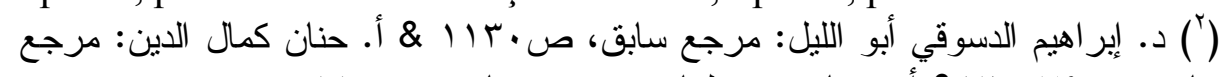

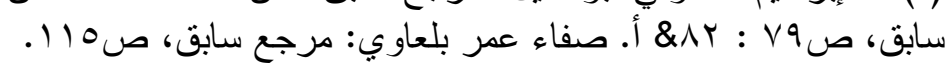

$\left(^{3}\right)$ Philippe Rodier, op. cit., p. 101 \& Jean - François Gervais, op. cit., p. 5 . 
بحسب الاتفاق، ومجموع الأقساط يمتل ثمن شر اء الطائرة مع تغطيــة كافــة المصروفات بالإضافة إلى هامش ربح معقول للمؤجر الائتماني (').

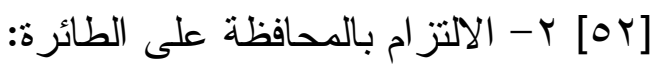

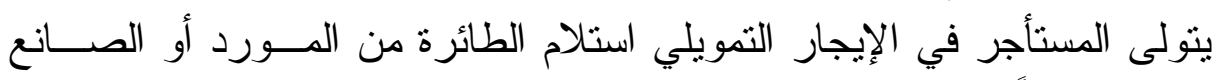

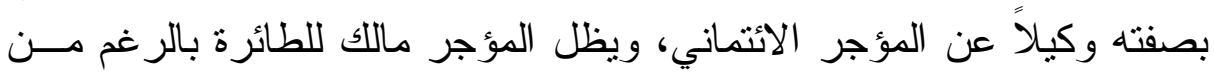

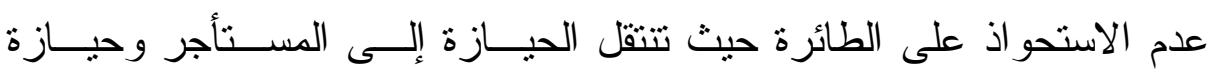

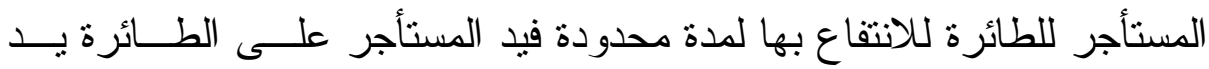
عارضة تزول بنهاية عقد الإيجار التمويلي.

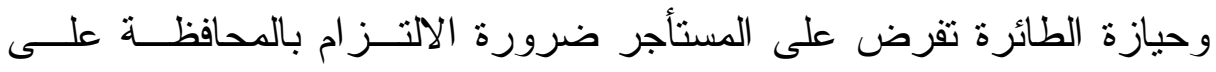

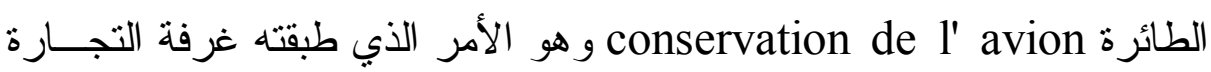

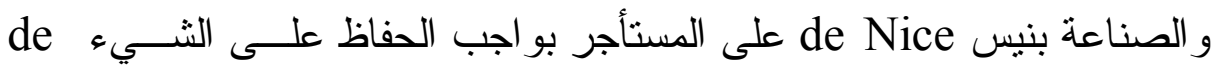
voir de garde de la chose

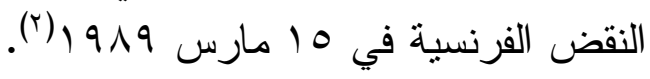
و الالنز ام بالمحافظة على الطائرة يتطلب من المســتأجر القيــام بالالتز امــات التالية: [0r] أ- الالتز ام بحسن استخدام الطائرة:

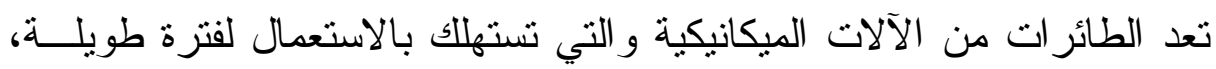

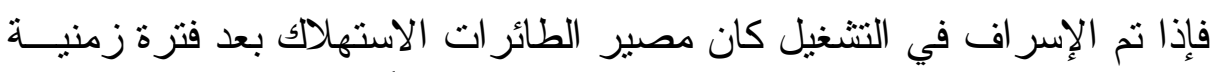

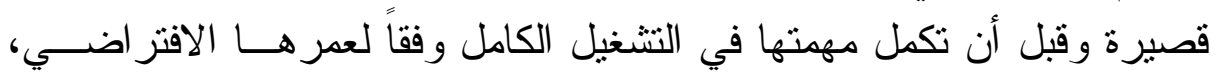
فسوء الاستخدام للطائرة يؤدي إلى تقصير العمر الاستهالاكي للآلة، ويعرضها

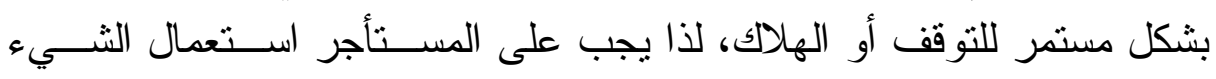

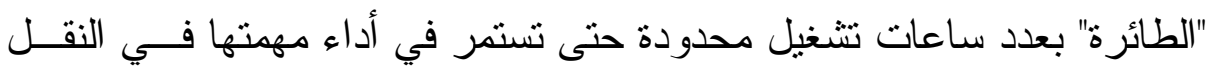

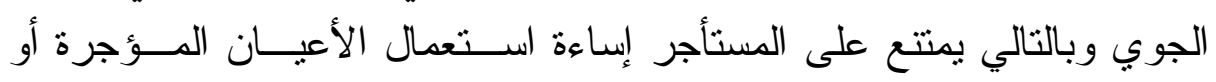

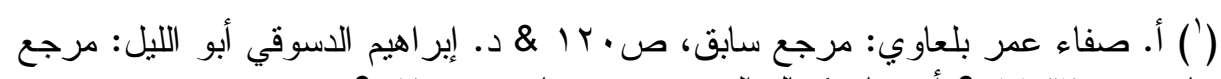

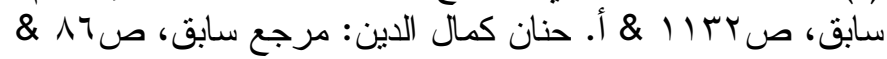
Philippe Rodier, op. cit., p. 102 \& Jean - François Gervais, op. cit., p.6. $\left(^{2}\right)$ Cass. Civ, 15 Mars 1989, N87-17287, sur le site, easydroit.fr/jurisprudence 
استعمالها بطريقة غير طبيعية، و لا يجوز تجاوز نظام التتغيل حتى لا يشـــل إفر اطاً في الاستعمال (1). ويتطلب استعمال الطائرة الحصول على التز اخيص و إنهاء الإجر اءات الإدارية

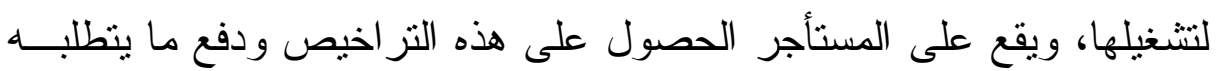

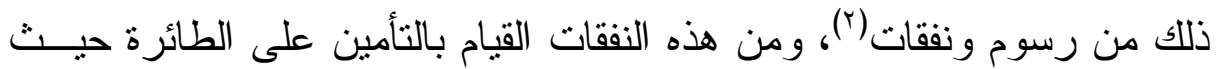

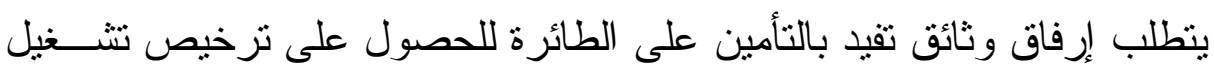

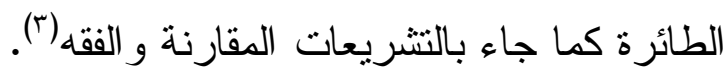

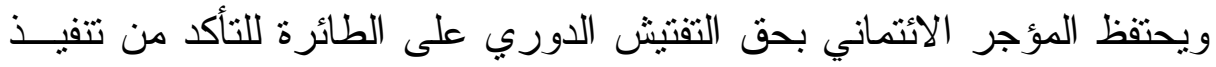

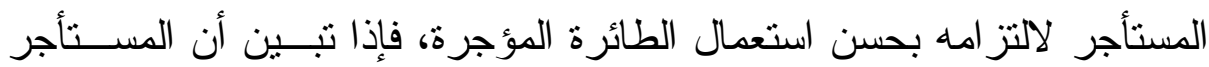

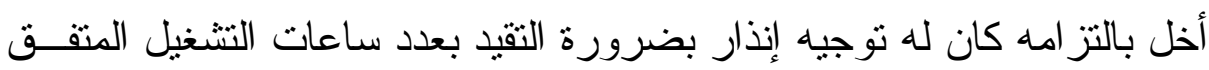

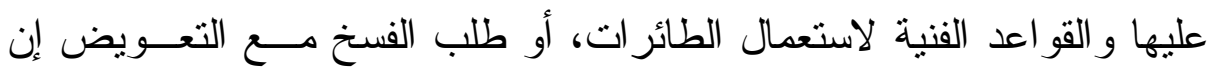
كان هنالك مقتضى لذلك (£). [ــ] ب - الالتز ام بصيانة الطائرة:

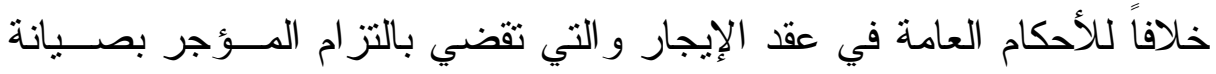

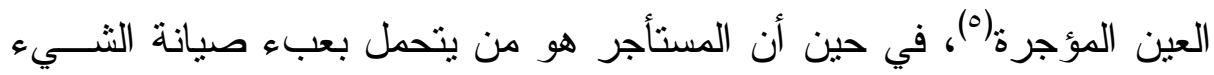

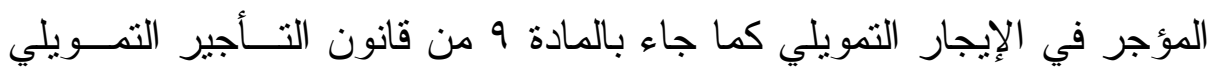

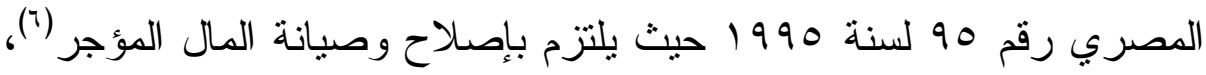

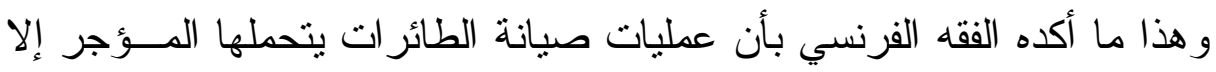

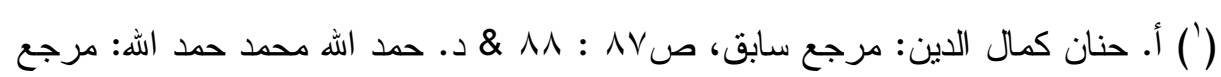

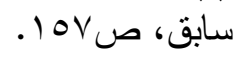
Jean - François Gervais, op. cit., p. 5 \& Philippe Rodier, op. cit., p. 101.

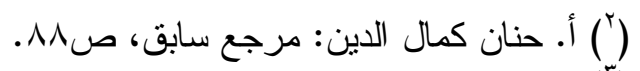

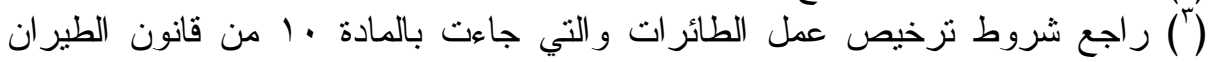

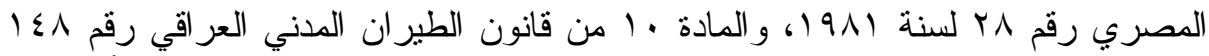

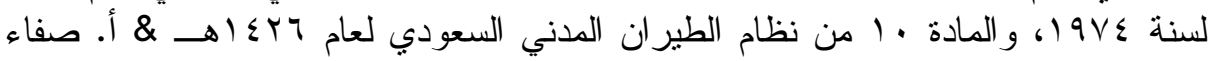

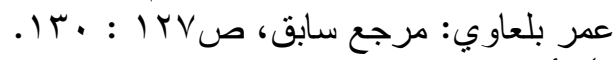

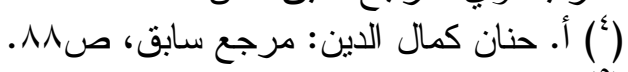

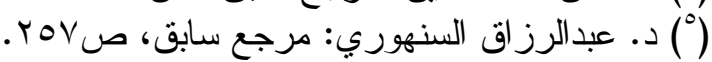

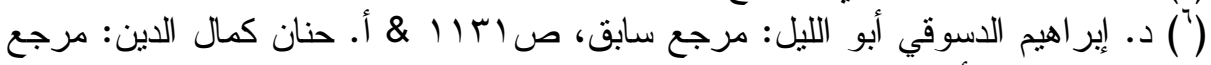

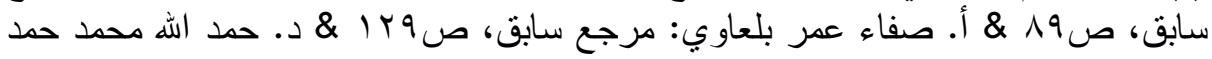
الله: مرجع سابق، صنو صل أ. 
إذا كانت مدة التعاقد طويلة فيتحملها المستأجر وينقل إلبــــه الالتــز ام كليــاً(')، وتتحمل شركة الطير ان "المستأجر" المسئولية الفرديــة seule responsable

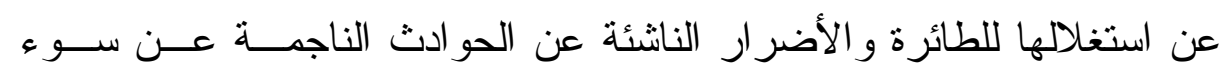

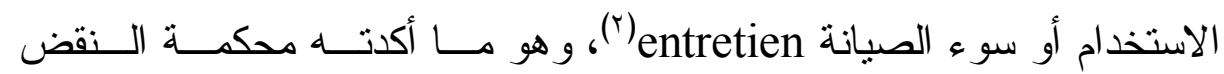

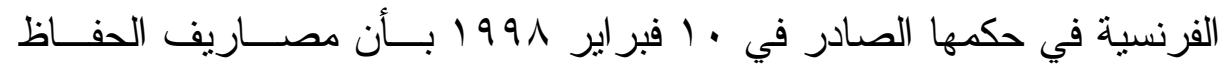
على الطائرة وصيانتها و التأمين عليها ثقع على المستأجر في الإيجار التمويلي

.${ }^{(r)}$ le crédit - bail

ج- الالتز ام بإخطار المؤجر بمشاكل الانتفاع:

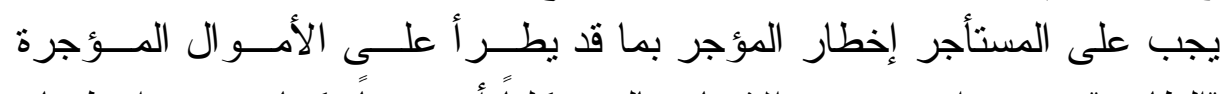

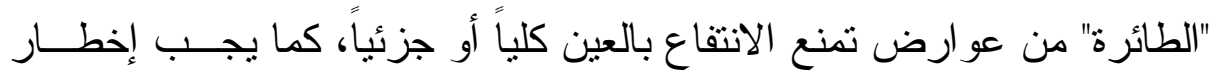
المؤجر بأي عيب يلحق بالعين المؤجرة و أي نقص يلحق بالأصول المــؤجرة أو بذمته المالية(ع).

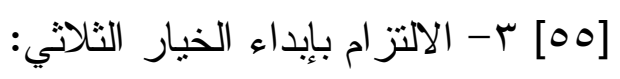

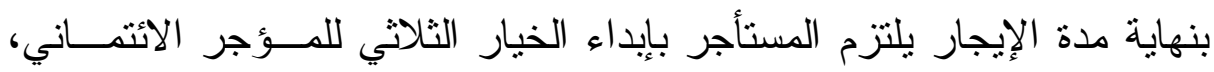

ومضمون الخيار الثناتي أن يختار المستأجر أحد الخيار ات الثالثة التالية(ه): أ- خيار الثر اء option d' achat للطائرة محل التــأجير التمــــيلي بقيمـــة محددة في العقد وهو الثمن الباقي valeur resideuelle بعد الأقساط المسددة خلال فتزة الإيجار، ونظر اً لأهمية هذا الاختيار اعتبر الفقه الفرنسي أن عملية التأجير التمويلي le crédit - bail إيجار لأمو ال بقصد الثــر اء outillage

( ' ') achetés

( $\left.{ }^{1}\right)$ Philippe Rodier, op. cit., p. 155.

( $\left.{ }^{2}\right)$ Philippe Rodier, op. cit., p. 96 et p. 108.

$\left(^{3}\right)$ Cass. Com, 10 Février 1998, N95-16643, sur le site, www.legifrance.gouv.fr

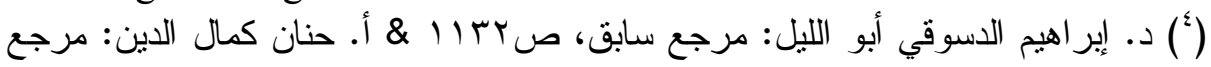

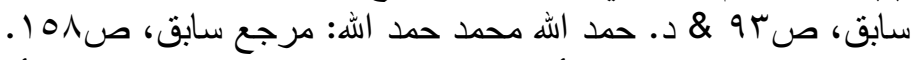

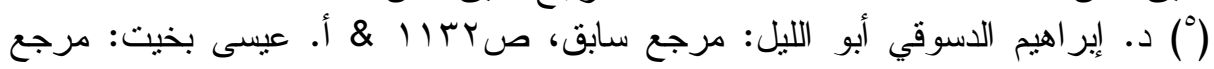

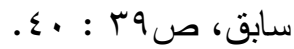

$\left({ }^{6}\right)$ Florent Vigny, Timothée Bertrand, op. cit., p. 9 \& Philippe Rodier, op. cit., p. 98 \& Jean - François Gervais, op. cit., p. 3 et p. 7 \& Louis Payette, op. cit., pp. 31:32. 


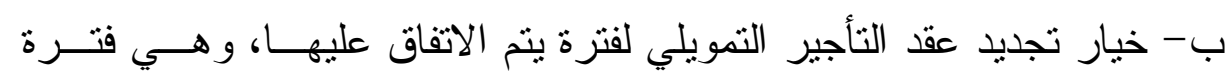

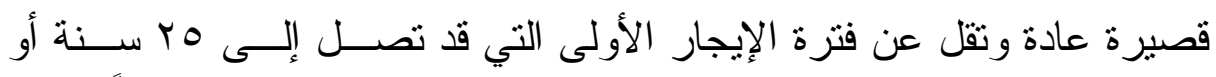

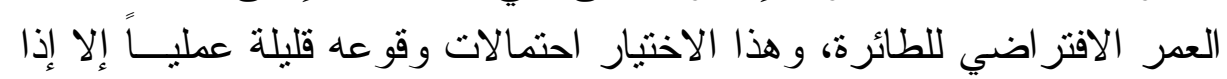

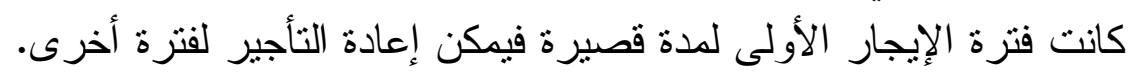

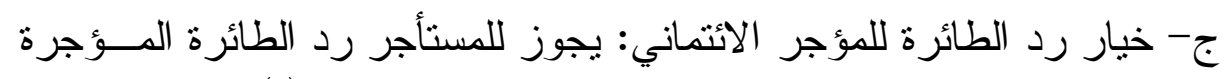

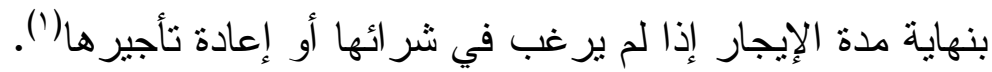

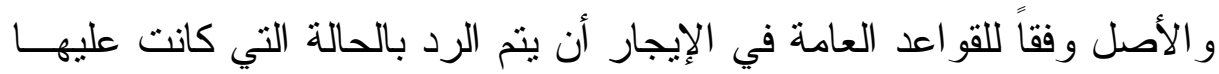

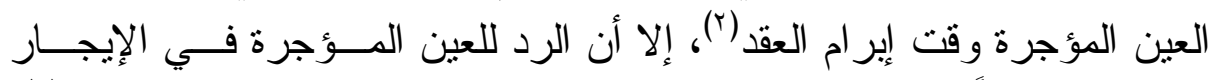

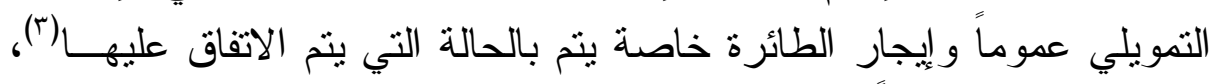

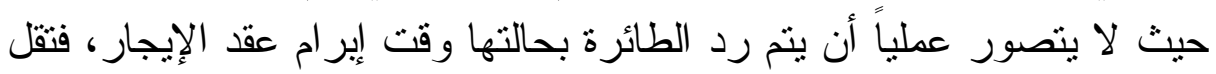

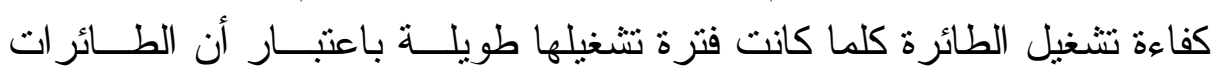

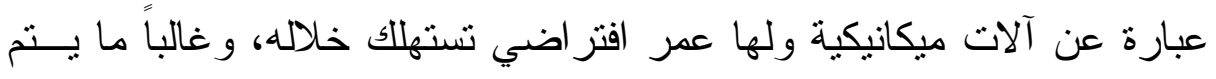

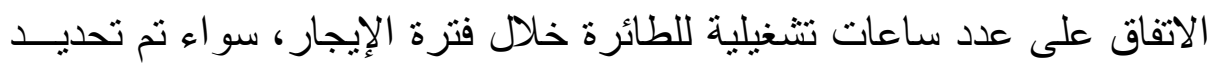

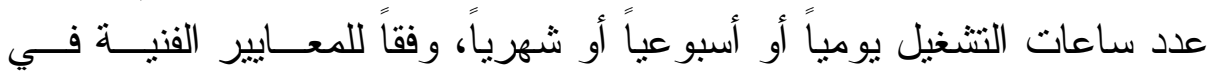

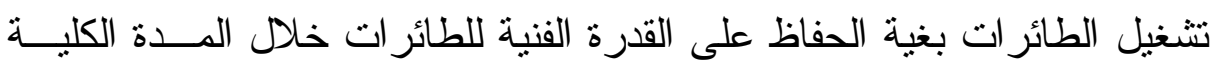

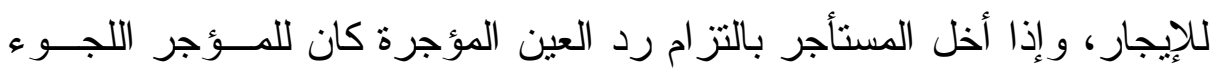

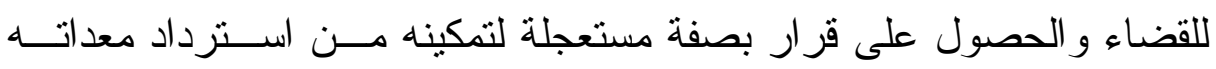

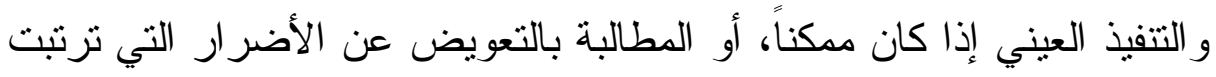

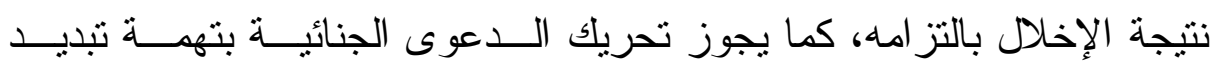

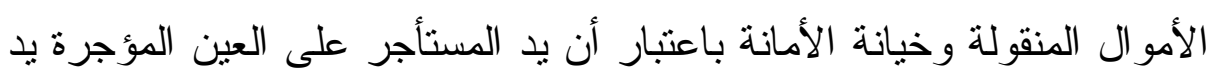

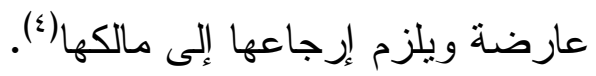

( $\left.{ }^{1}\right)$ Philippe Rodier, op. cit., p. 97.

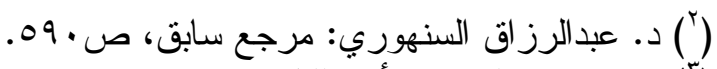

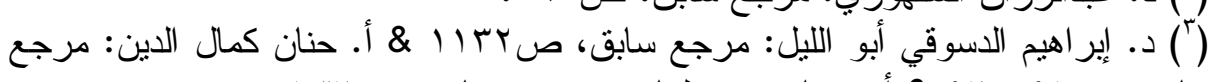

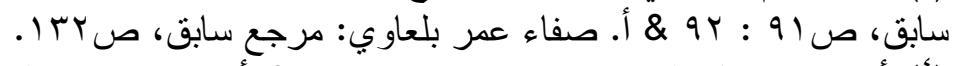

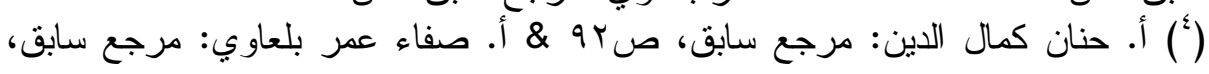




\section{المبحث الثالث}

\section{المسئولية عن أضرار الطائرات المستأجرة}

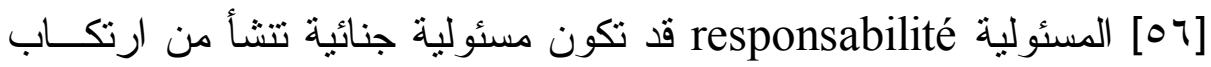
شخص لفعل معاقب عليه بنص القانون وفقاً لقاعدة لا جريمـــة و لا عقوبـــة إلا

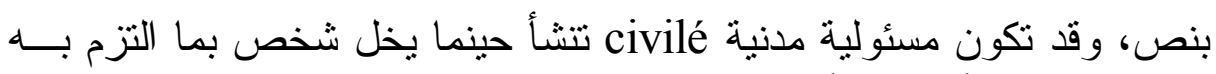
تجاه الغير قانوناً أو اتفاقا، و الجز اء فيها تعويض الضرر الناشئ عـنـ الفعـل

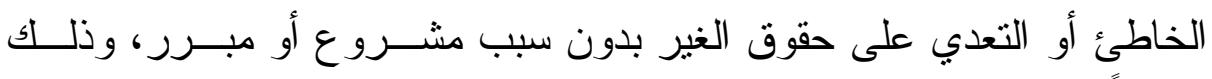

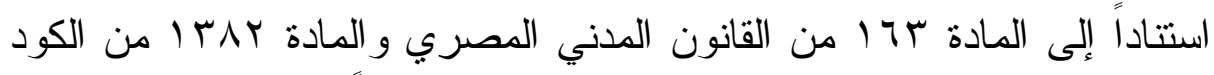
المدني الفرنسي و التي تقضي بان كل خطأ سبب ضرر اً للغير يلزم من ارتكبه بالتعويض (1) ومجال الدر اسة يتتاول المسئولية المدنية فقط، وتلك المســؤلية تتقســم إلـى بـى مسئولية عقدية تتشأ بوجود إخلال بأحد العقود، ومســؤلية تقصــيرية تتشــأ بموجب ارتكاب فعل ضنار دون ارنباط بعقد، وعناصــر المسـئولية المدنيــة بنو عيها و احدة بوجود خطأ وضرر و علاقة سببية بينهما، وقد سبق الذكر فـي

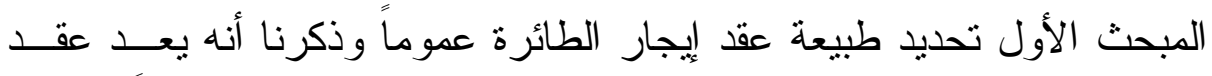

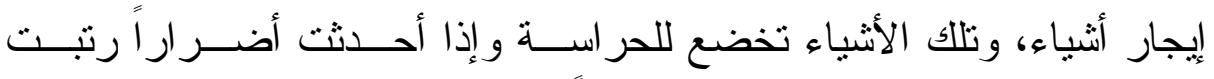

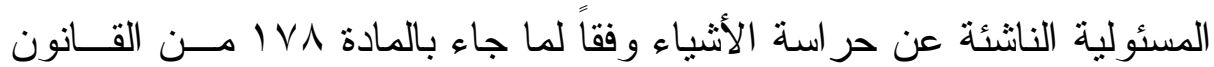
المدني المصري و المادة عدبا من الكود المدني الفرنسي (ז).

(') د. جميل الثرقاوي: النظرية العامة للالتز ام، الكتاب الأول "مصادر الالتزام"، دار

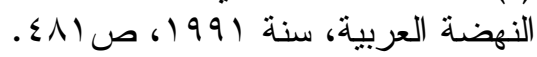

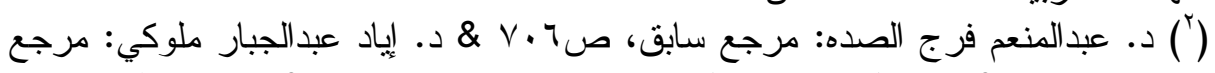

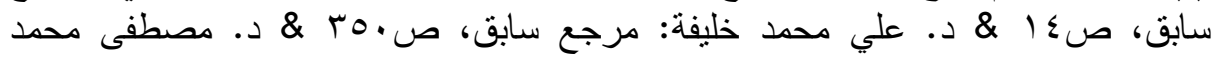

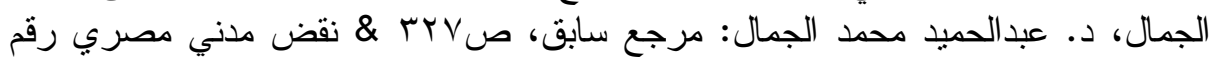
9V0

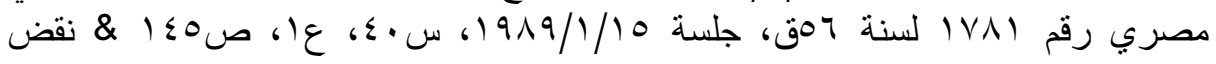

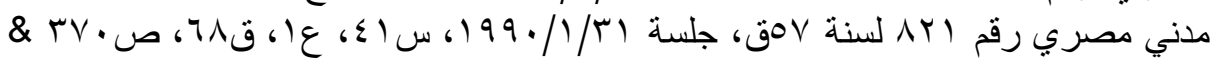

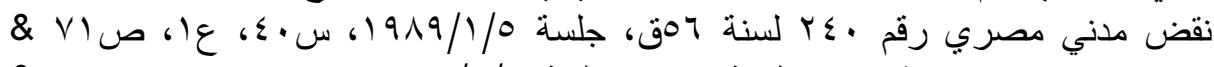

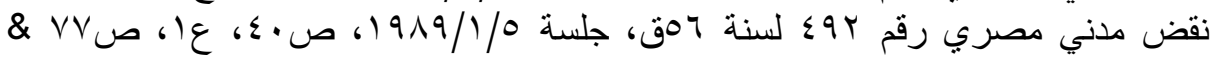
نقض مدني مصري رقم

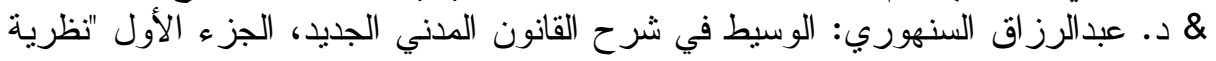

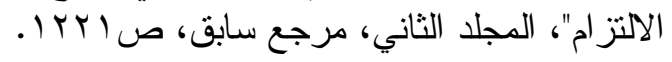


و إز اء تعدد صور تأجير الطائر ات وما ترتب عليها من اخــتلاف الالتز امــات

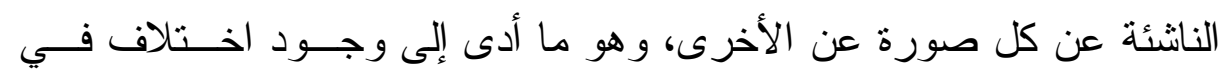

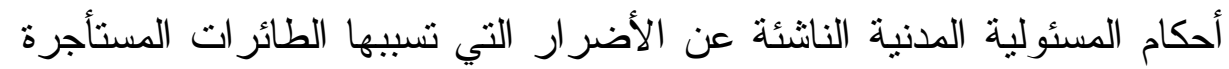

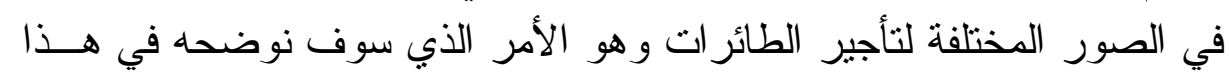

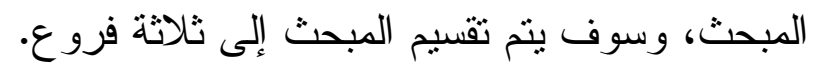

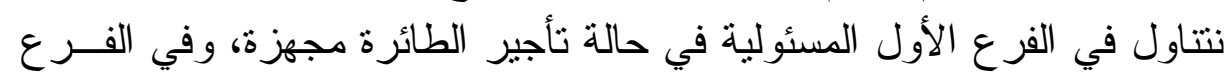

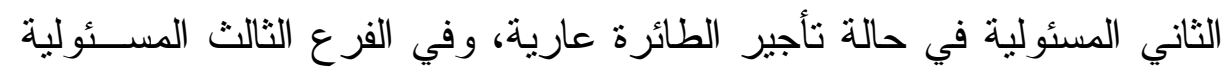
في حالة التأجير التمويلي للطائرة.

\section{الفرع الأول}

\section{المسئولية في حالة تأجير الطائرة مجهزة الأول}

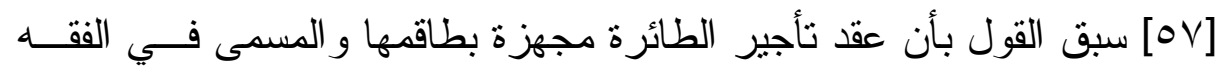

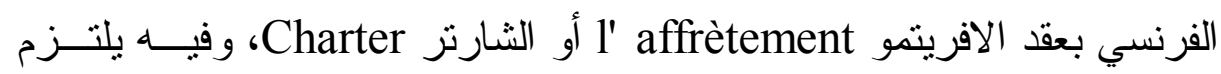

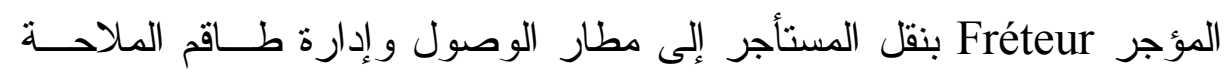

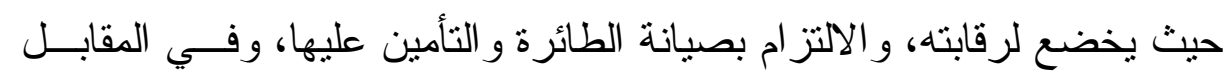

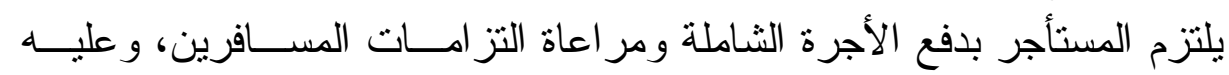

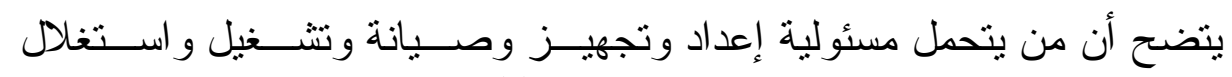
الطائرة هو المؤجر ، كما يتولى نقل المستأجر (').

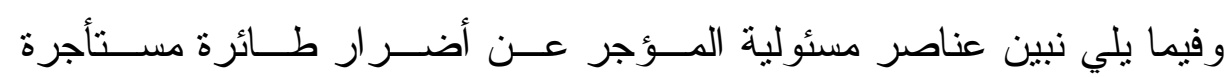
ومجهزة، وحالات المسئولية وطرق دفع المسئولية.

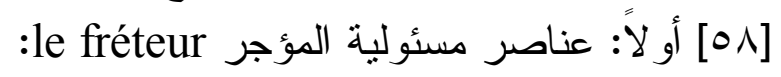

Philippe Rodier, op. cit., p. 61 et p. 99 \& CAA de Lyon, 1 Octobre 2015, N14LY00444 \& CAA de Douai, 21 Mars 2006, N05DA00156 \& Cass. Civ, 27 Février 2007, N03-16683, les sentences sur les site, www.legifrance.gouv.fr

( $\left.{ }^{1}\right)$ Philippe Rodier, op. cit., p. 146 \& David Sprecher, op. cit., \& Cass. Com, 2 Octobre 2012, N11-21362 \& Cass. Com, 29 Septembre 2015, N14-11041 \& Cass. Com, 2 Octobre 2007, N06-14121 \& Cass. Civ, 5 Juillet 2001, N99-11520, les sentences sur le site, Www.legifrance.gouv.fr 
وفقاً للأحكام العامة في المسئولية المدنية بشترط لتحققها تو افر عناصر ها مــن خطأ وضرر و علاقة سبيية بينهما. ا - خطأ المؤجر: يتمنل خطأ المؤجر في الإخلال بالتز ام عقدي، أو التشــبـ في حدوث أضرار للغير، و المؤجر هنا بمثابة ناقـلـ جــوي aérien

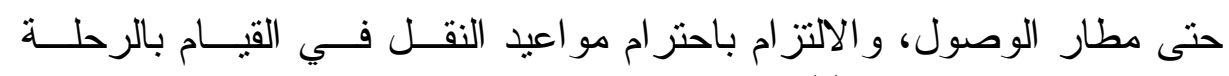
ونهايتها بتوقيت الوصول(')، كما يتحمل المؤجر خطأ تابعيه من طقم الملاحــة الجوية كالطيار و غير ه ممن بخضعون لرقابته و إدارته(r).

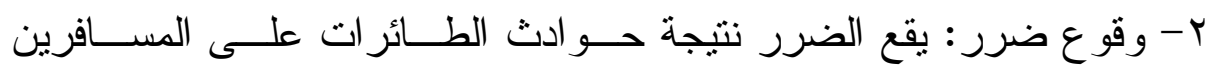
و أمتعتهم، كما يقع الضرر على السطح للغير، ويتمثل الضرر في ضرر مادي

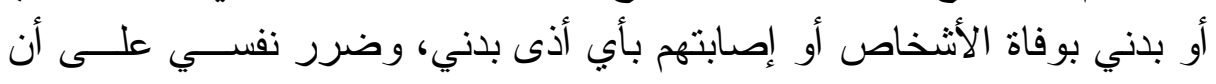

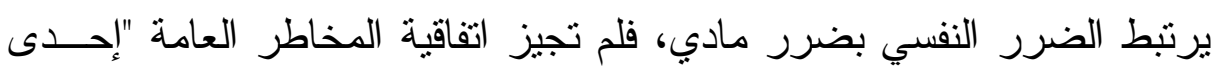

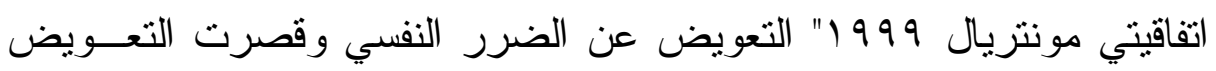

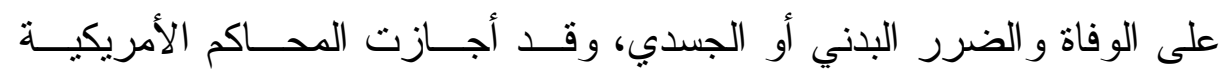

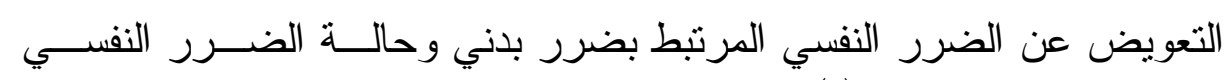
المؤدي إلى ضرر مادي (r).

(') د. إبر اهيم عبدالرحمن: مسئولية الناقل الجوي وأثز ها في التعويض، بحث بالمؤتمر

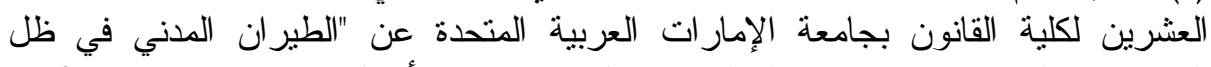

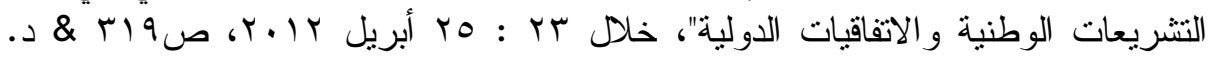

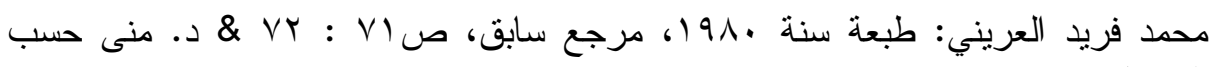

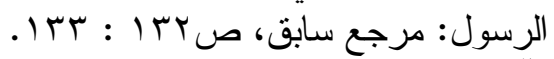

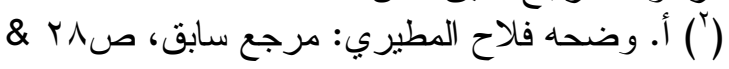

David Sprecher, op. cit., \& Cass. Com, 2 Octobre 2007, N06-1421 \& Cass. Com, 2 Octobre 2012, N11-21363 \& Cass. Civ, 6 Juin 1990, N88-18991, les sentences sur le site, www.legifrance.gouv.fr (") د. إبر اهيم الأرناوؤط: مدى مسئولية الناقل الجوي عن الأضر ار النفسية وفقاً لمعاهدة

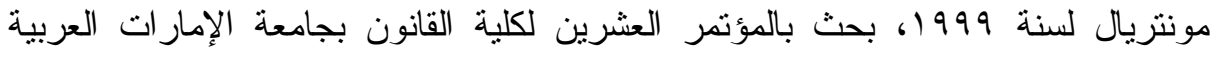

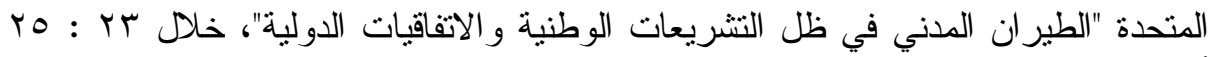

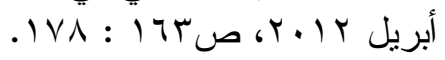


r- علاقة السبيية: تتحقق علاقة السببية بأن يكون حادث الطائرة نتيجة خطــأ

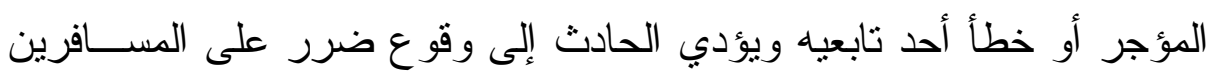
و أمتعتهم أو على الغير على سطح الأرض.

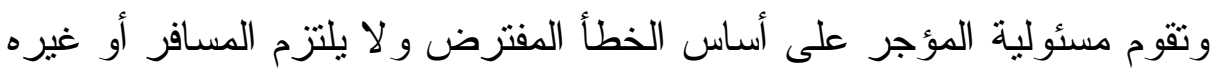

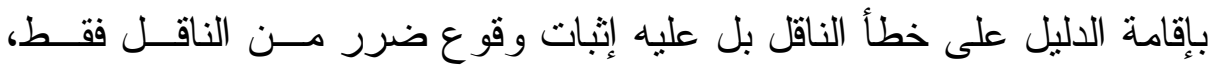

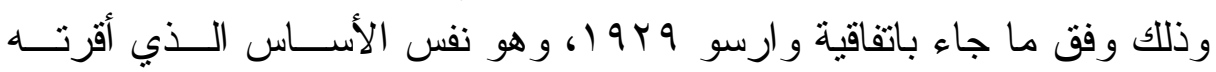

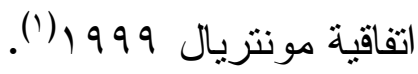

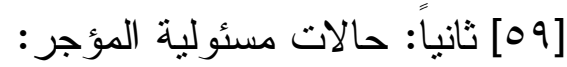
تتحقق مسئولية المؤجر بعد تو افر عناصر ها في الحولة الحالات التالية:

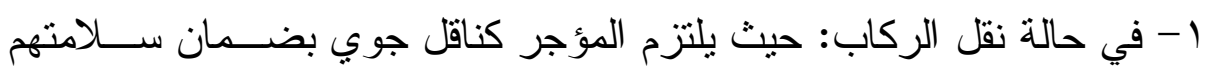

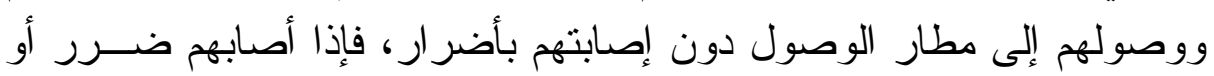

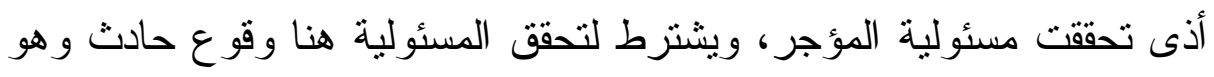

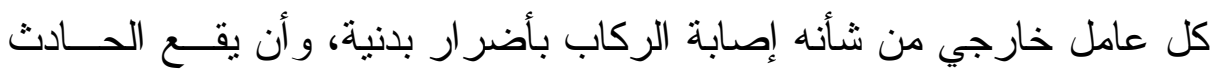

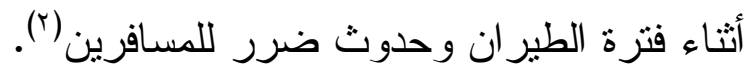

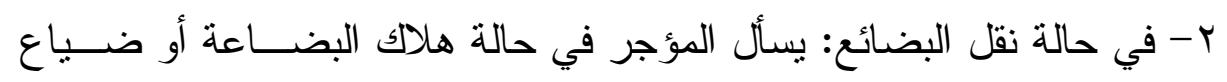

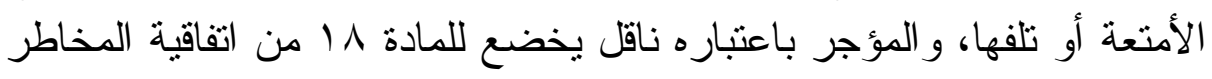

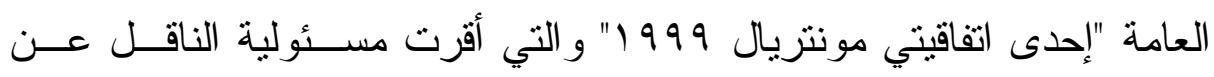

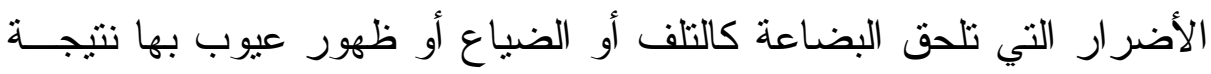

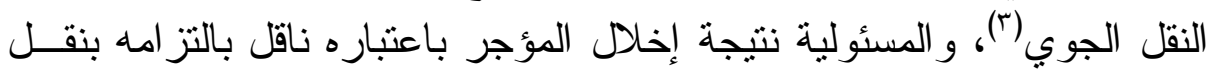

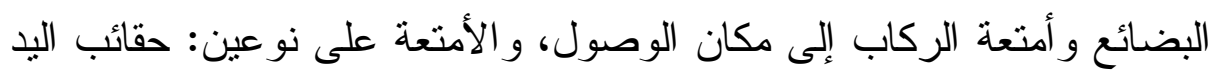

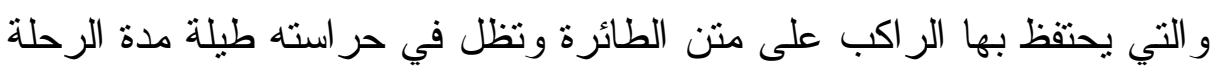

(') د. عبدالحميد خلف العنزي: أساس مسئولية الناقل الجوي وحالاتها، بحث بالمؤتمر

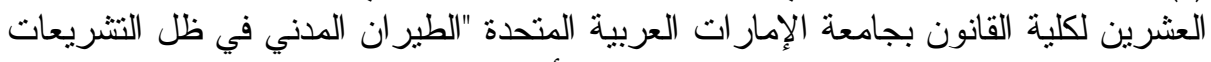

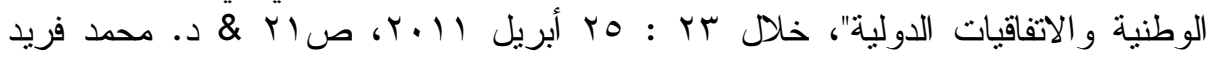

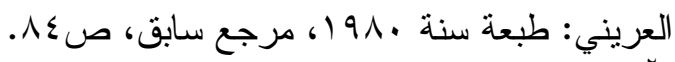

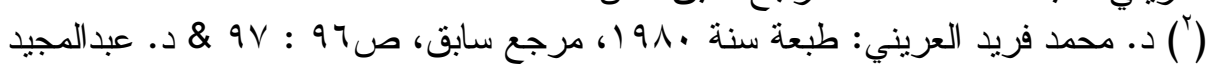

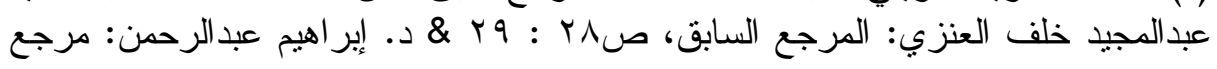

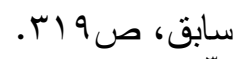

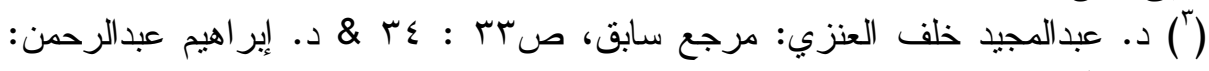

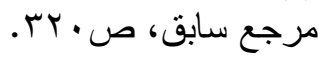


الجوية، و الأمتعة المسجلة و التي يتخلى عن حيازتها المادية في مطـــار القيــام

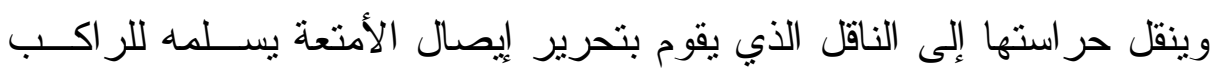

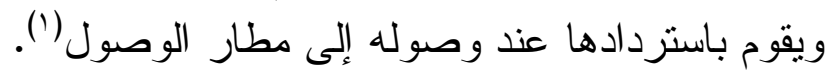

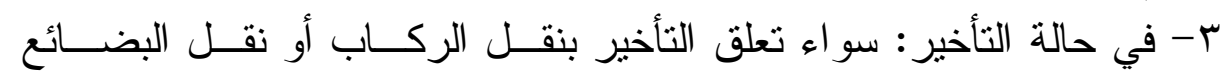

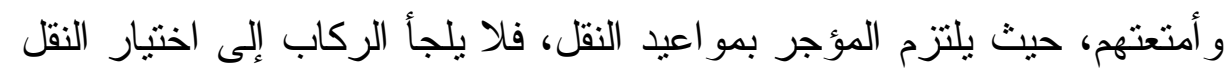

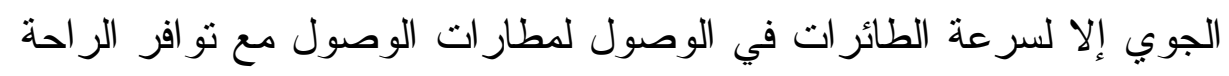

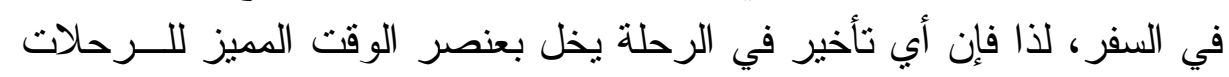

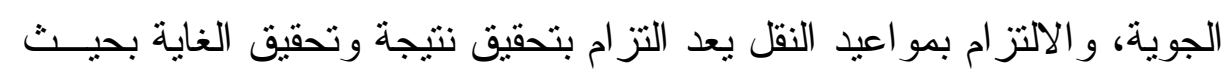

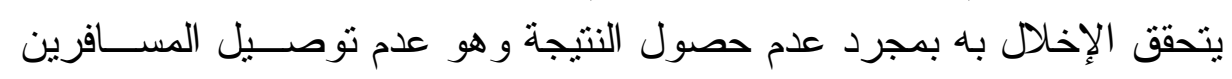

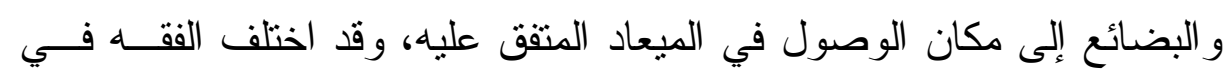

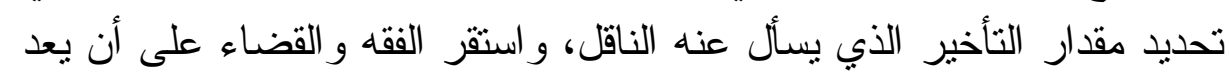

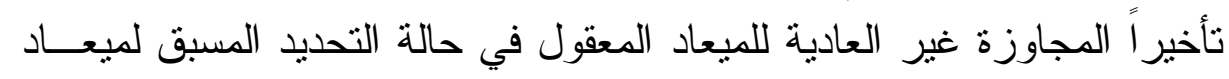

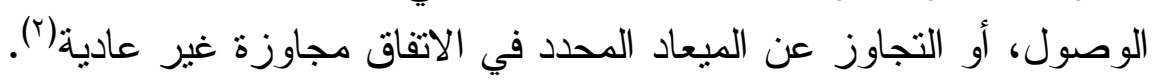

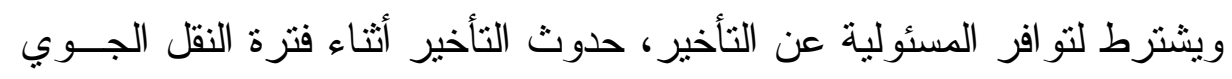

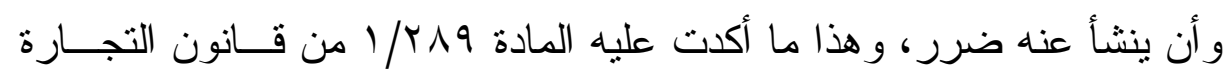

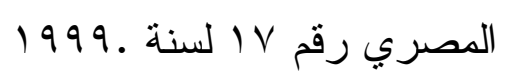

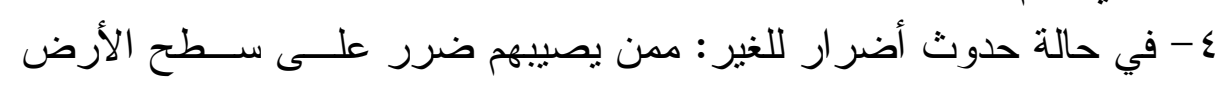

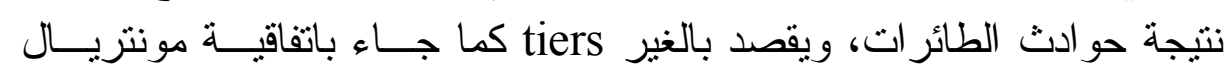

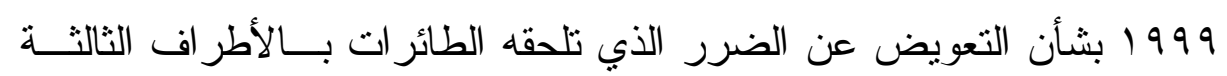

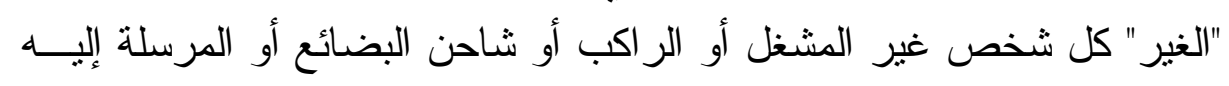

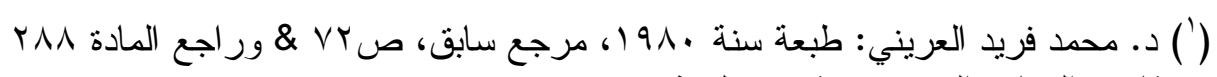

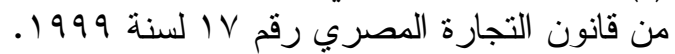

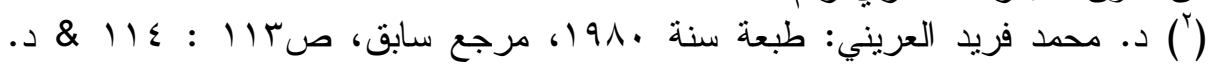

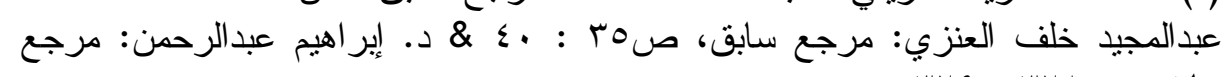

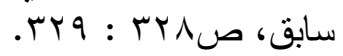




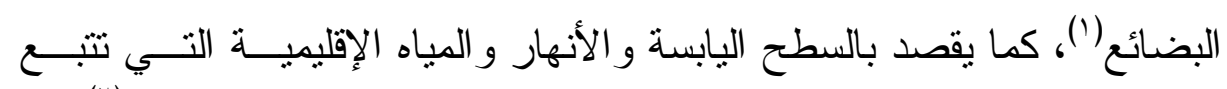

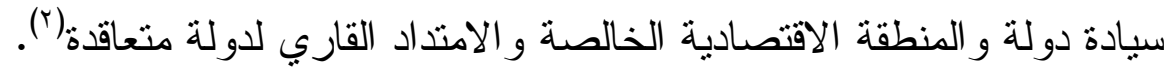

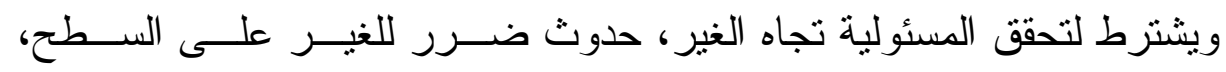

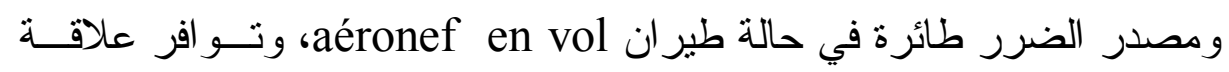

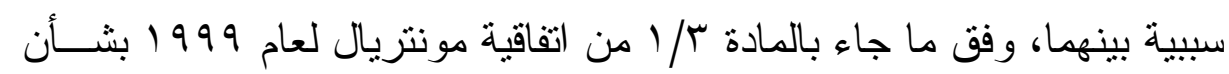

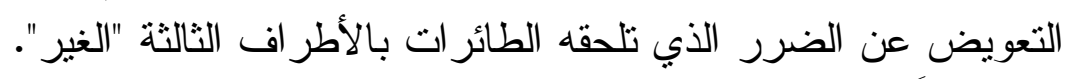

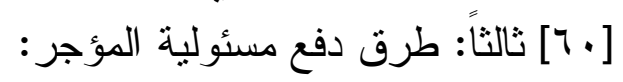

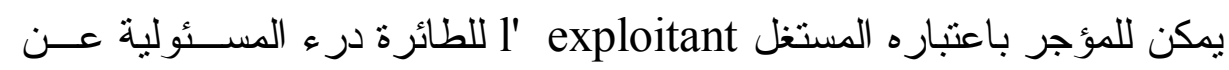

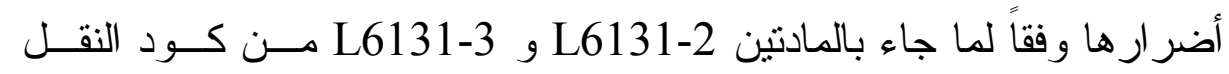

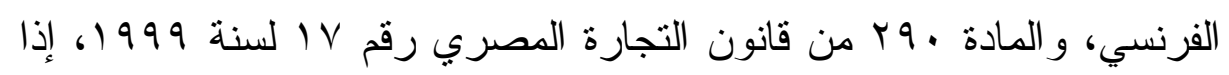

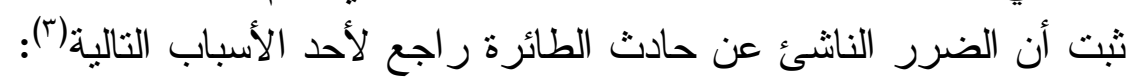

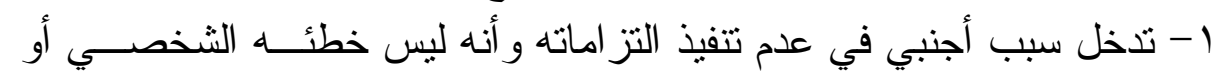
خطأ أحد تابعيه من العاملين بطاقم الملاحة الجوية.

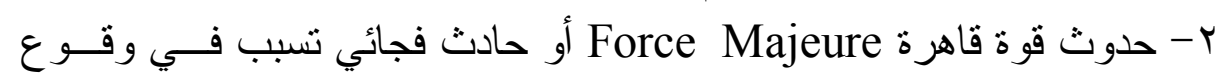

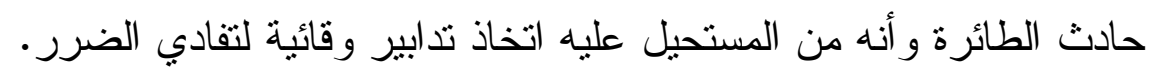

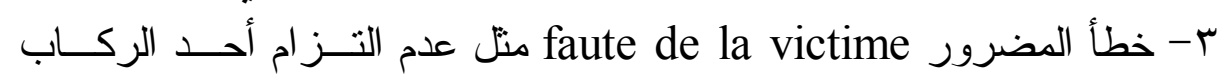

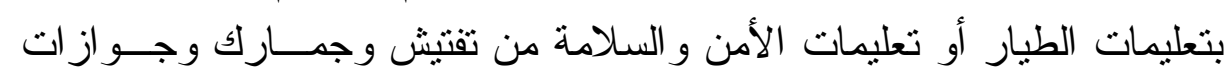
و الرقابة الصحية. ع - وقوع الضرر نتيجة نز اع مسلح أو اضطر ابات مدنية أو مظاهر ات.

(') راجع المادة //ط من اتفاقية مونتريال 1999 بشأن التعويض عن الضرر الذي تلحقه www.icao.int/meetings

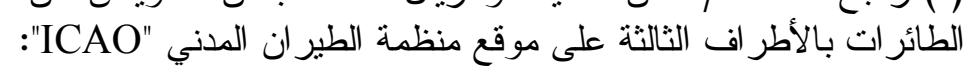

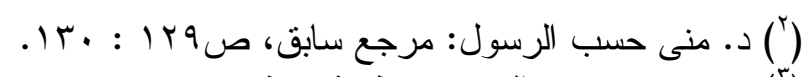

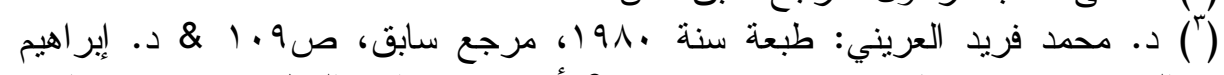

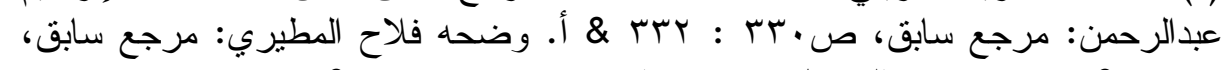

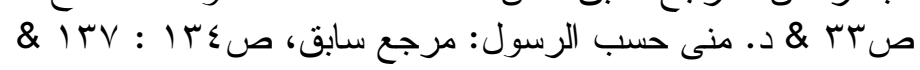
Thierry Mazoyer, la responsabilité du transporteur dans le carde d'un transport aérien international de marchandises, sur le site, cmhavocats.fr/fr/9 \& Cass. Com, 30 Juin 2015, N13-28846 \& Cass. Com, 2 Octobre 2012, N11-21362, les sentences sur le site, www.legifrance.gouv.fr 
0- منع استعمال الطائرة بو اسطة السلطات العامة لوجود إجر اءات أمنيـــة أو

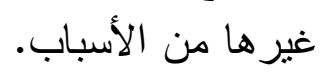

\section{الفرع الثاني}

\section{المسئولية في حالة تأجير الطائرة عارية}

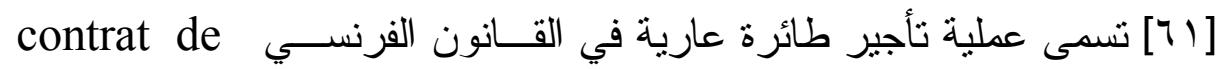
location

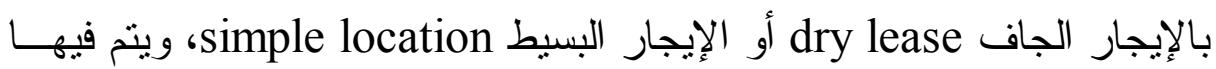
تأجير الطائرة بدون طاقم فيتولى المستأجر تعيين طاقم الملاحة الجوية، و عادة الجادئ

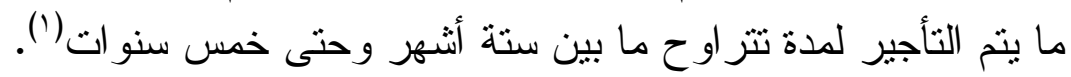

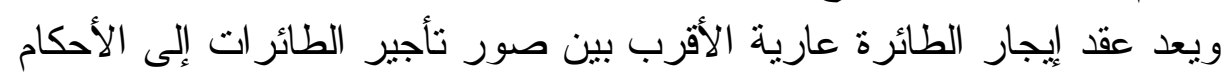

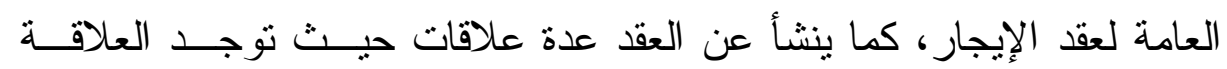

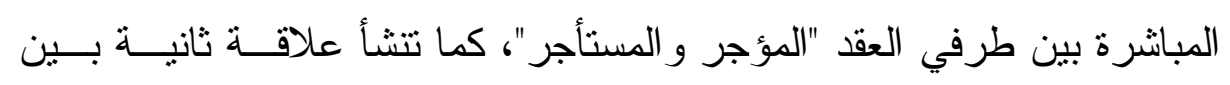

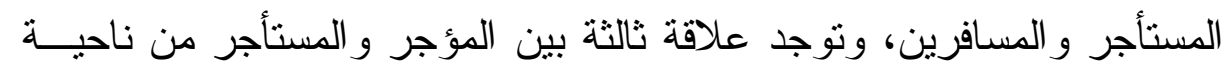

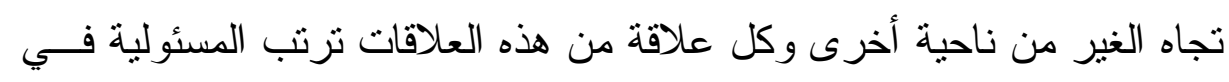

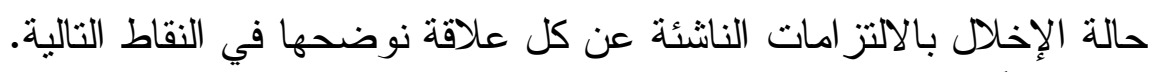

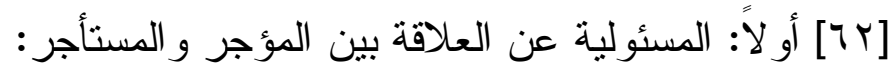

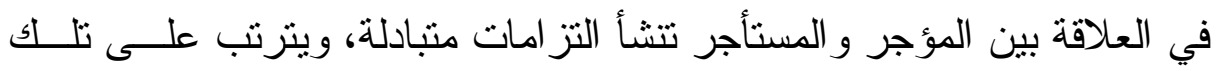

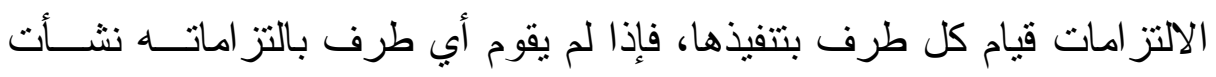

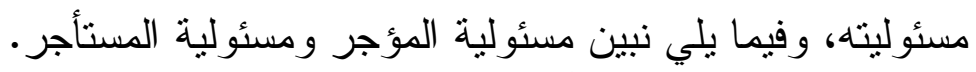

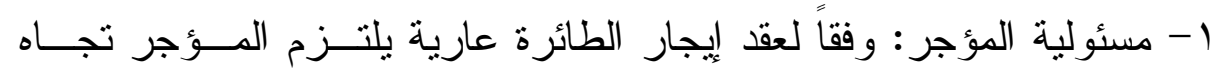

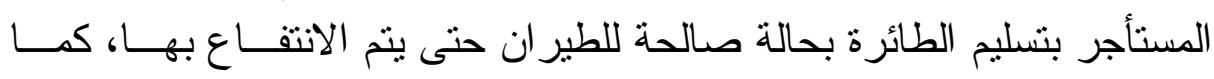

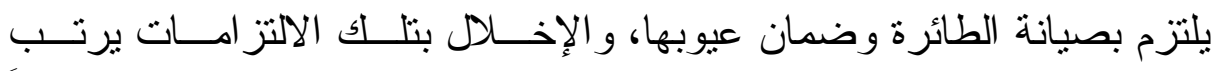
مسئوليته ويحق للمستأجر طلب التتفيذ العيني إذا كان ممكنا، فإذا لم لم يكن ممكناً

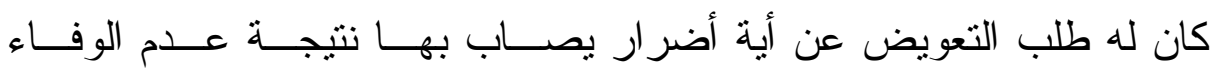

( $\left.{ }^{1}\right)$ Philippe Rodier, op. cit., pp. 147:148 \& Florent Vigny, Timothée Bertrand, op. cit., p. 20 \& د. منى حسب الرسول: مرجع سابق، ص r I I \& أ. وضحه فلاح المطيري: مرجع سابق، 
بالالتز امات، و عليه إثبات تحقق المسئولية المدنية من خطأ المــؤجر وحــدوث ضرر ووجود علاقة سببية بينهما. ץ- مسئولية المستأجر : تتشأ عن العقد التزامات على المستأجر بدفع الأجــرة

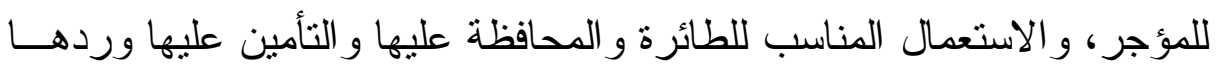
بنهاية مدة الإيجار، فإذا أخل بأي من تلك الالتز امات كان للمؤجر حق طلــب التتفيذ العيني إذا كان مدكناً أو طلب التعويض بتو افر عناصر المســئولية مــن فئن خطأ وضرر و علاقة سبيية بينهما. [T7] ثانياً: المسئولية عن العلاقة بين المستأجر و المسافرين:

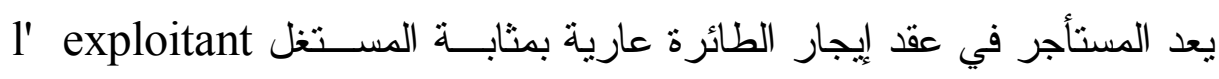
للطائرة حيث بقوم بالانتفاع بtilise بها وفق ما جاء بالمادة r/r من اتفاقيــة روما بشأن المسئولية عن الأضر ار المحققة للغير على السطح من الطـائر ات

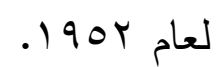

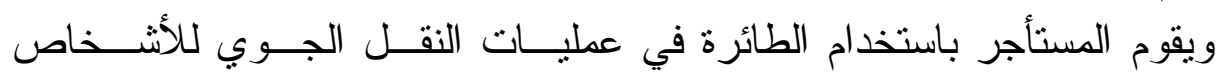
و البضائع وبالتالي فهو الناقل الجوي في علاقته مع المسافرين، و عليه أن يلتزم

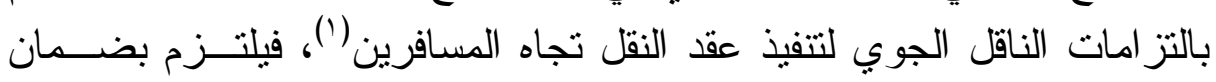

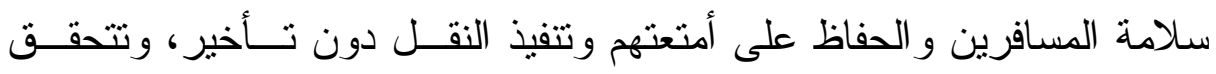

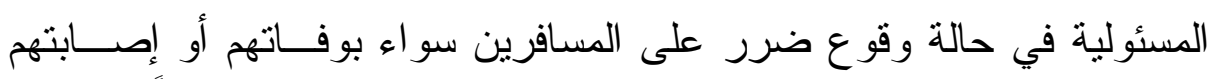
بأذى أو فقدان أمتعتهم أو تلفها، أو التأخير عن ميعاد الوصول وفقــاً لأحكــام

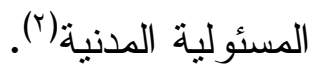
[؟ 7] ثالثاً: المسئولية عن العلاقة بين طرفي العقد مع الغير : في حالة وقوع حو ادث للطائر ات المستأجرة وتسببت في إلحاق الضرر بالغير

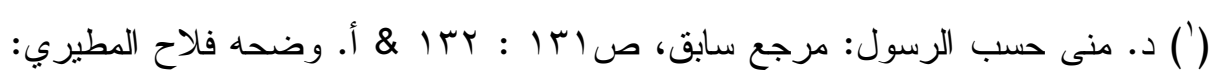

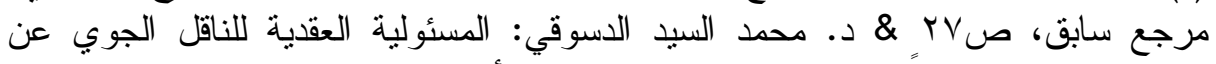

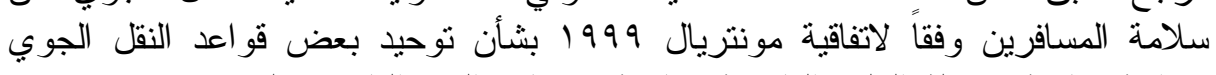

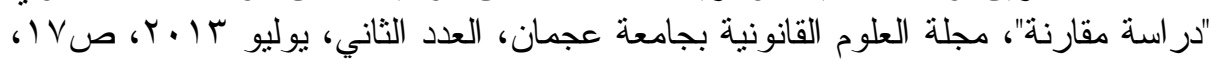
مناح على الموقع: \& issuu.com/ajmanuniversity/docs Philippe Rodier, op. cit., p. 148 et p. 156.

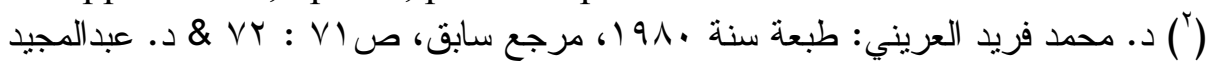

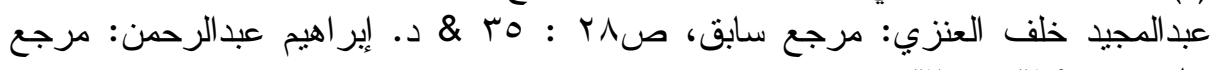

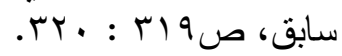


على سطح الأرض، فمن يتحمل المسئولية تجاه هذا الغير.

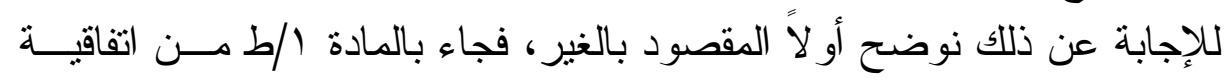

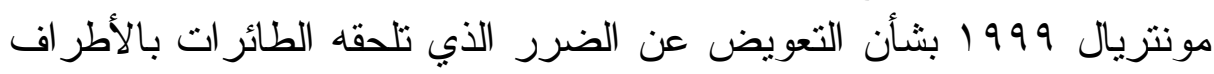

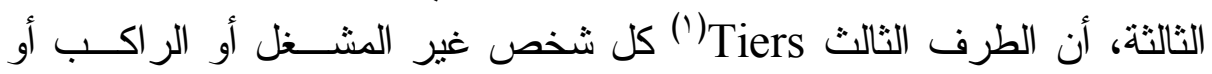
شاحن البضائع أو المرسلة إلبه البضائع.

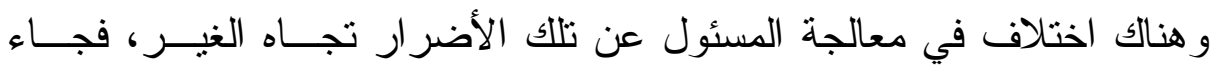

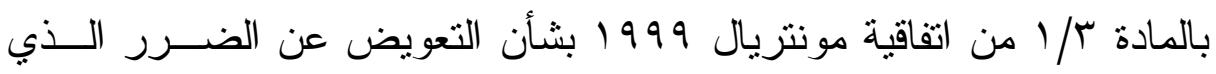

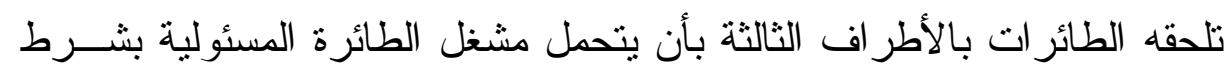

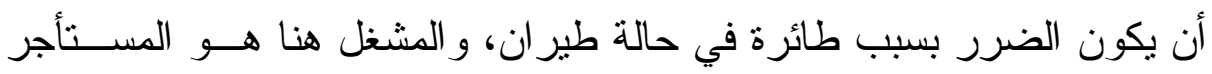

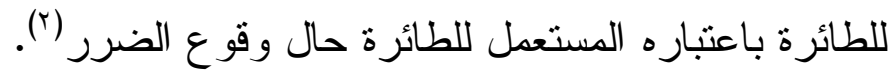

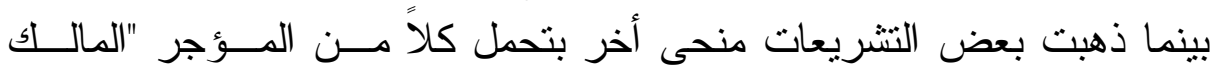

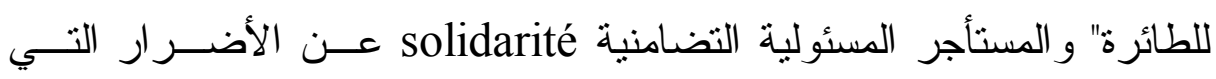

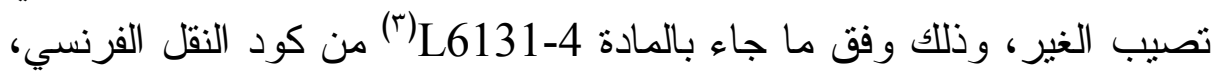

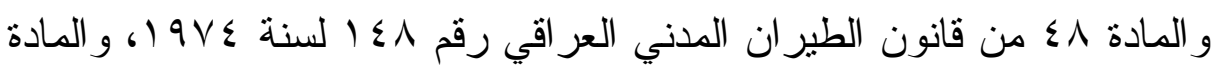

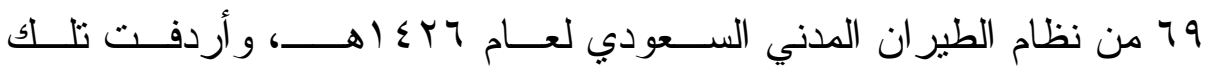

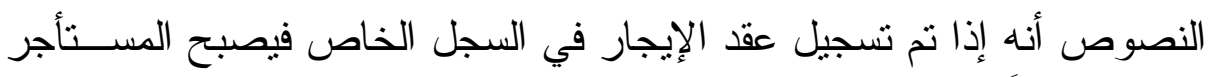

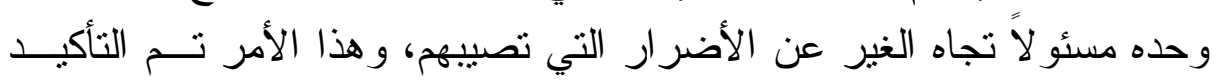

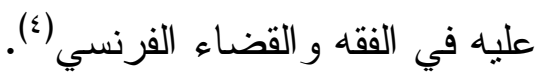

(') نم نشر اتفاقية مونتريال 1999 على موقع المنظمة الدولية للطيران المدني "الأيكاو"

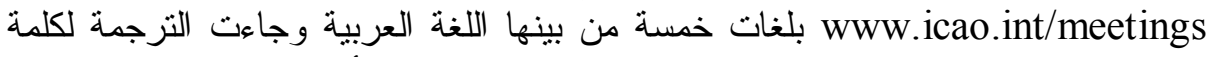

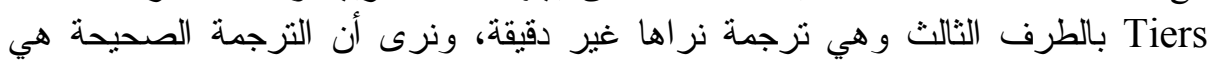
(') د. منى حسب الرسول: مرجع سابق، ص ابّا \& \& د. حمد الله محمد حمد الله: مرجع

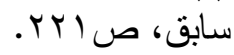
(") المادة 46131 من كود النقل الفرنسي حلت محل المادة 4-141-14 من كود الطيران

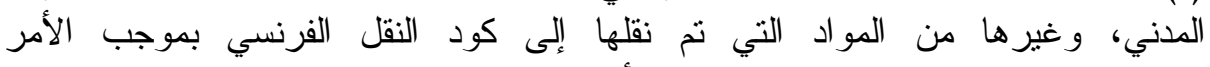
ordonnance $\left(^{4}\right)$ Philippe Rodier, op. cit., p. 149 \& Michel Asencio, op. cit., p. 9 \& Florent Vigny, Timothée Bertrand, op. cit., p. 18 \& Cass. Civ, 12 Mai 2004, N01-14259 et N01-14931 \& Cass. Civ, 9 Octobre 1979, N7812503, les sentences sur le site, www.legifrance.gouv.fr 


\section{الفرع الثالث}

\section{المسئولية في حالة التأجير التمويلي للطائرة}

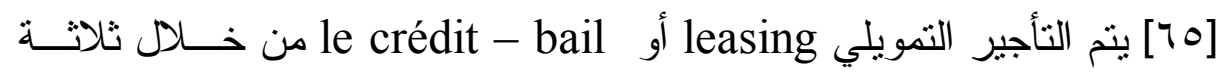

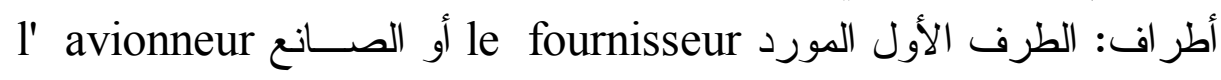
أو المقاول constructeur الذي يتولى تقديم الطائر ات محل الإيجار للمــؤجر

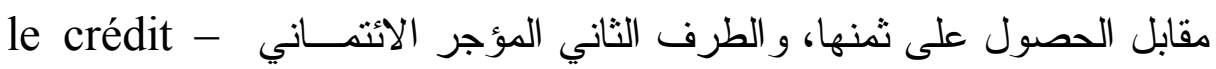
bailleur

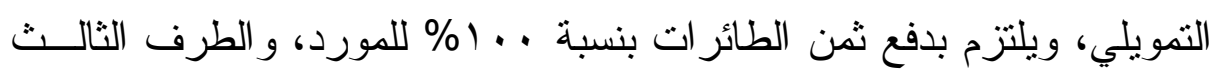

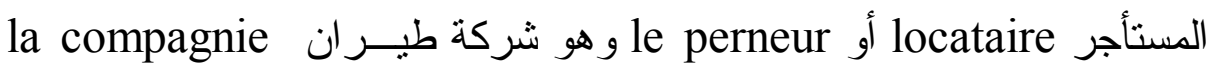

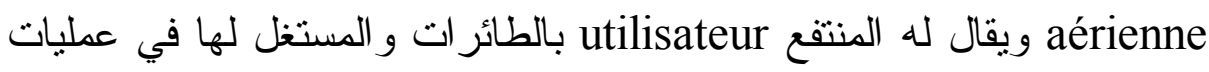

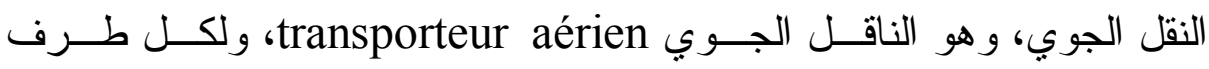
التز امات عليه الوفاء بها تجاه الآخرين.

وفيما يلي نوضح مسئولية كل طرف عن التزاماته وذللك في النقاط التالية.

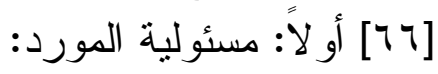

وفقاً لعقد التأجير التمويلي يلتزم المورد بتشليم délivrance الطائر ات محــل

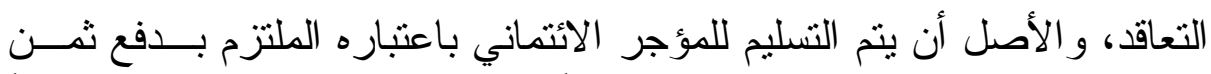

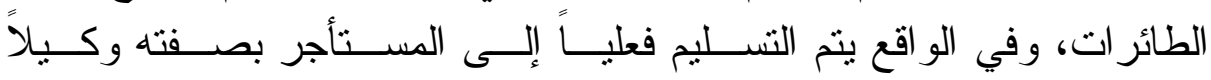
mandataire العقد باطلاً مطلقاً

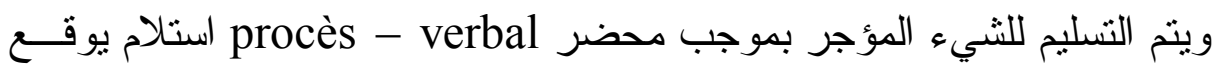

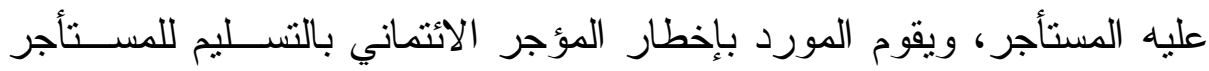

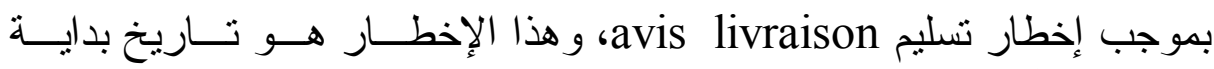
الإيجار وفقاً لما جاء بأحكام محكمة النقض الفرنسية(r).

( $\left.{ }^{1}\right)$ Philippe Rodier, op. cit., p. 101 \& Jean - François Gervais, op. cit., p. 6 .

$\left({ }^{2}\right)$ Cass. Com, 13 Octobre 2015, N14-17118 et N14-17472 \& Cass. Com, 25 Octobre 2011, N10-15556 \& Cass. Com, 15 Octobre 2002, N99-21855 \& Cass. Com, 10 Décembre 1996, N95-10775, les sentences sur le site, www.legifrance.gouv.fr 
وتقوم على عاتق المورد المسئولية في حالة الإخلال بالتز ام تســليم الطــائرة، ويتحمل كافة الأضر ار الناجمة عن على عدم التسليم.

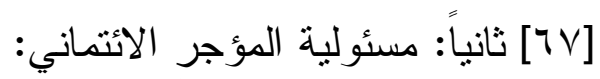

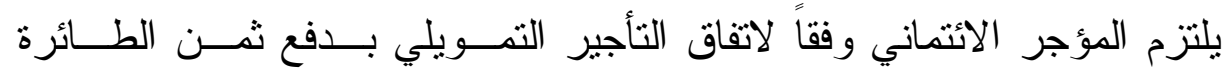

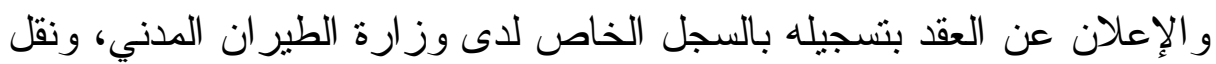

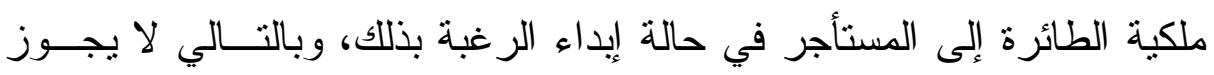

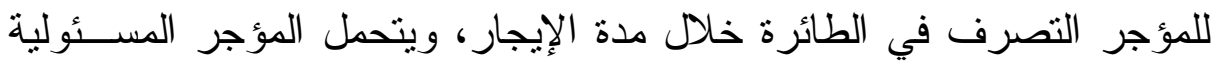

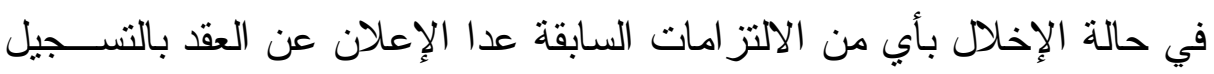

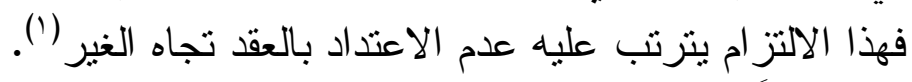

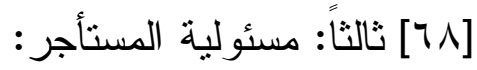

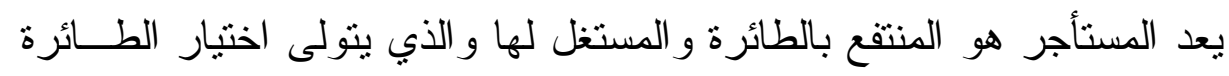

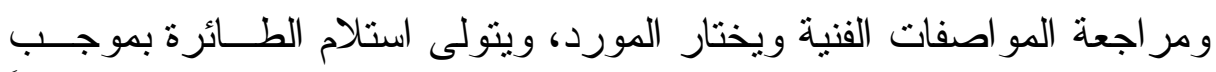

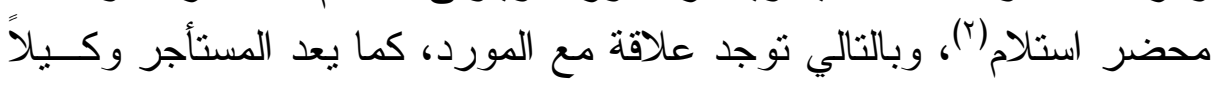

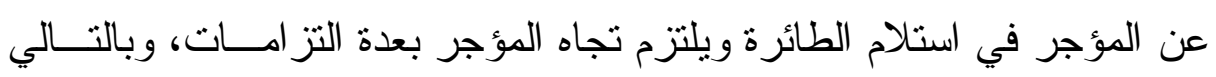

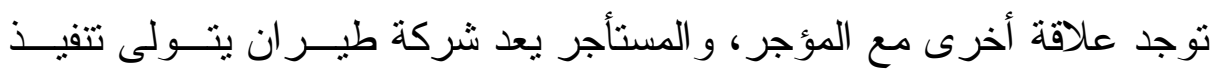
عمليات النقل الجوي، وبالتالي توجد علافة التربة ثالثة مع المسافرين.

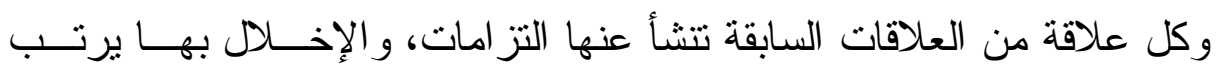

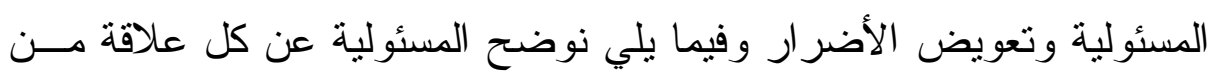
العلاقات الثلاث.

[79] 19 - مسئولية المستأجر تجاه المورد: يتعامل المستأجر مباثرة مع المورد

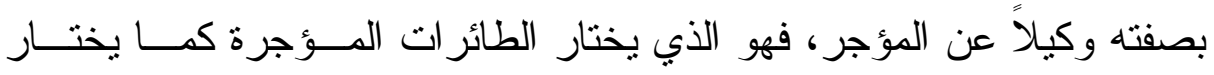

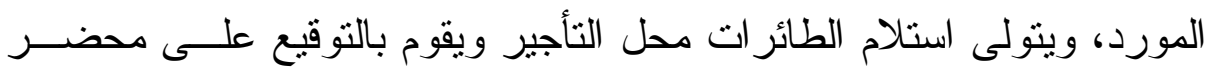

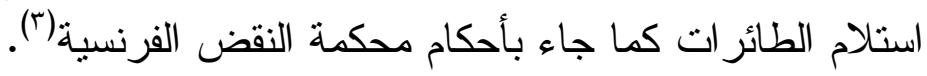

$\left.{ }^{1}\right)$ Philippe Rodier, op. cit., p. 102.

$\left(^{2}\right)$ Cass. Com, 10 Janvier 2012, N10-23891 \& Cass. Com, 25 Octobre 2011, N10-15556 \& Cass. Com, 15 Octobre 2002, N99-21855 \& Cass. Com, 11 Mars 2003, N01-13709, les sentences sur le site, www.legifrance.gouv.fr

$\left(^{3}\right)$ Cass. Com, 13 Octobre 2015, N14-17118 et N14-17472 \& Cass. Com, 11 Mars 2003, N01-13709 \& Cass. Com, 20 Janvier 1981, N79- 


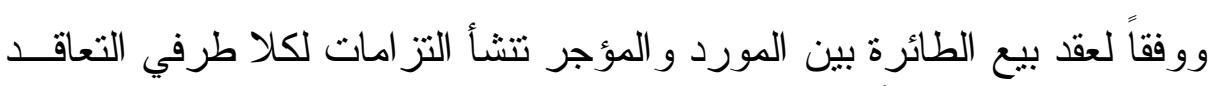

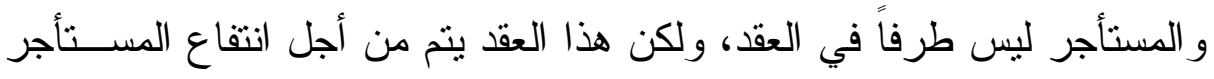

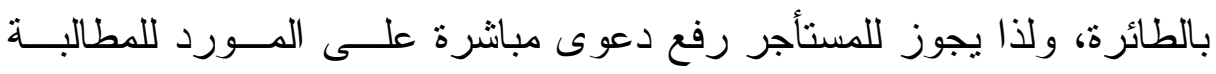

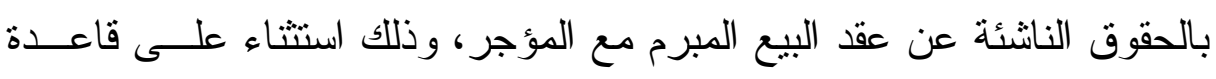

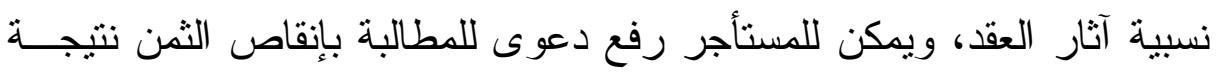

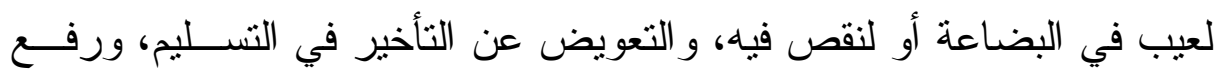

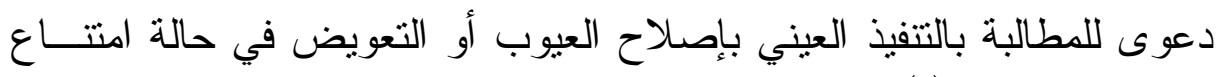

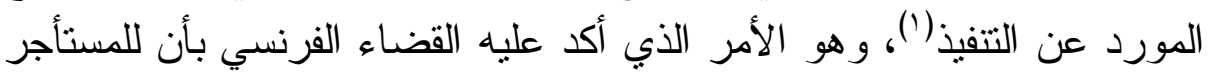
ممارسة دعاوى الرجوع recours ضد المورد نتيجة عدم احتر امه الاتقاقيات

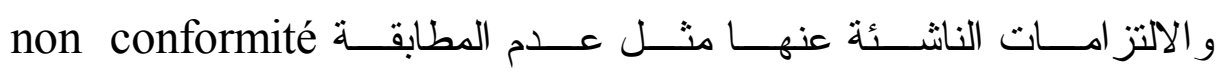
للمو اصفات(r).

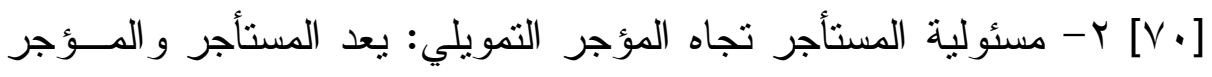
التمويلي طرفي عملية تأجير الطائرة، ويترتب على ذلك التزاه ام المستأجر بدفع

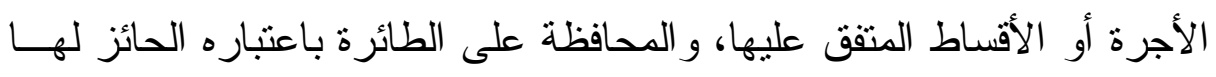

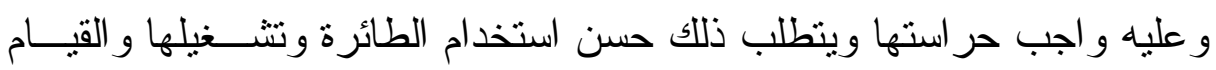

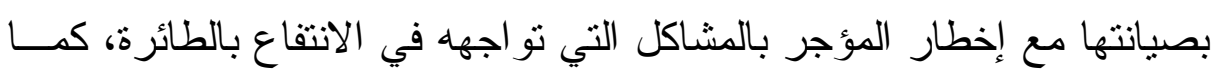

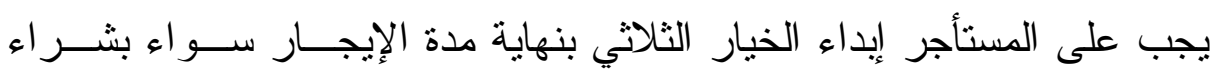

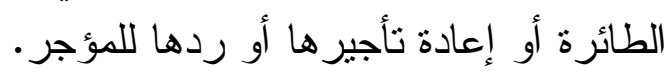

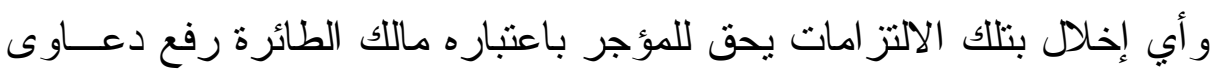

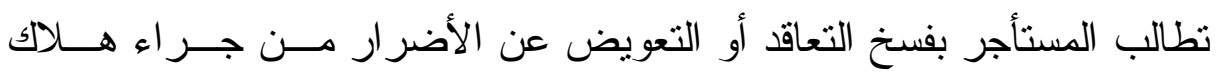
الطائرة أو إساءة استعمالها أو عدم الصيانة.

14601 \& Cass. Com, 11 Mai 1981, N79-15505 \& Cass. Com, 5 Juillet 1989, N86-16668 \& Cass. Com, 22 Mai 1991, N90-12116 \& Cass. Com, 15 Ooctobre 2002, N99-21855, les sentences sur le site, www.legifrance.gouv.fr

(') أ. صفاء عمر بلعاوي: مرجع سابق، صسب ا. $\left({ }^{2}\right)$ Cass. Civ, 8 Février 1984, N81-16228 \& Cass. Com, 13 Octobre 2015, N14-17118 et N14-17422 \& Cass. Com, 25 Octobre 2011, N1015556, les sentences sur le site, www.legifrance.gouv.fr 


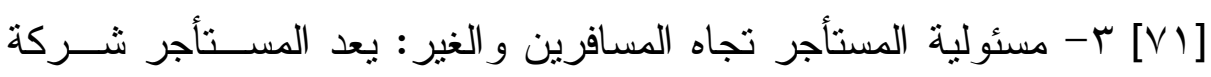

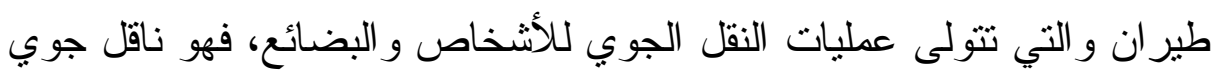

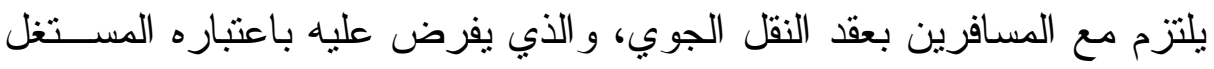

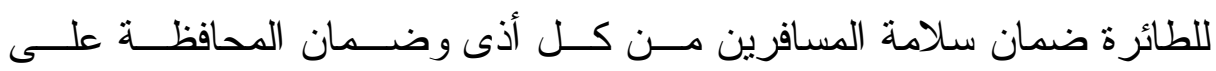

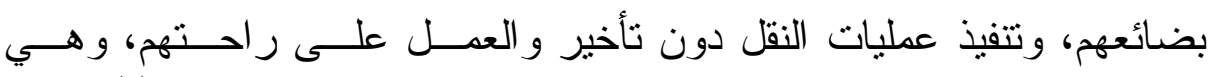

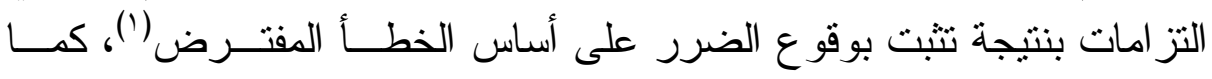

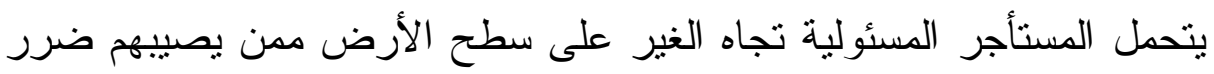

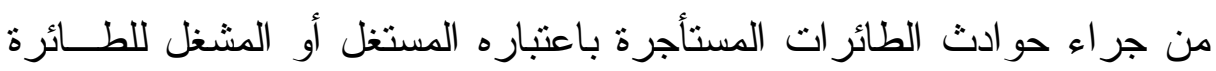

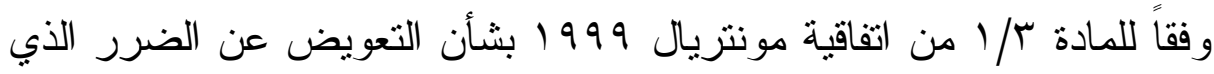

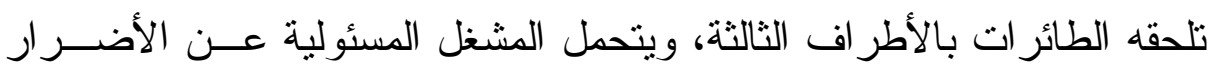

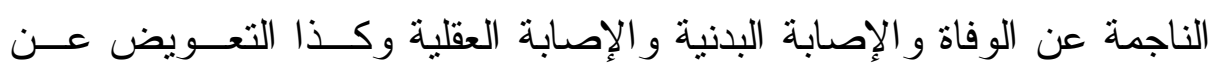

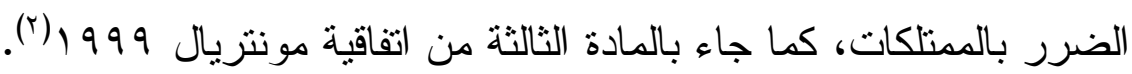

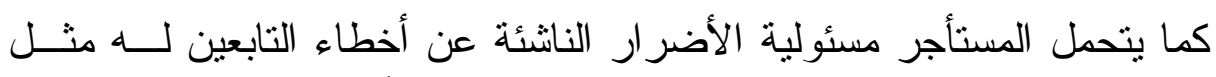

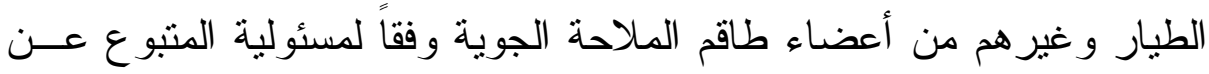

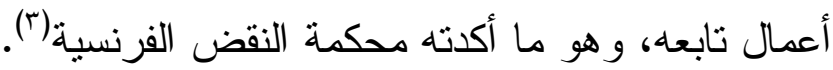

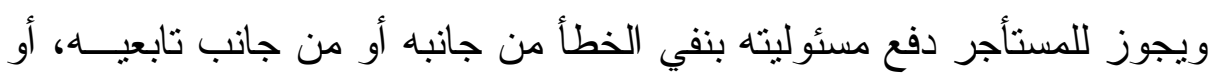

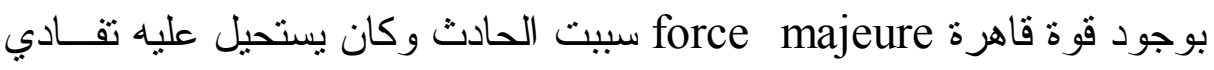

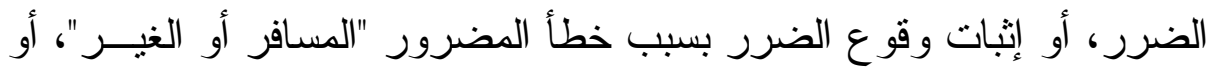

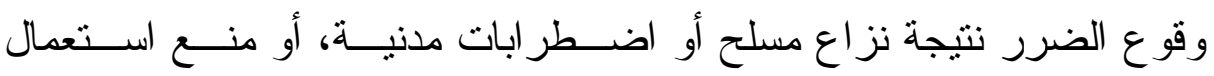

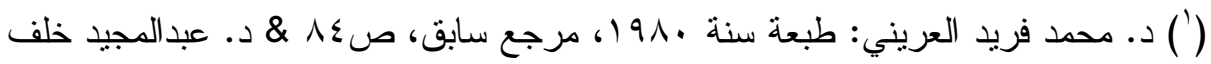

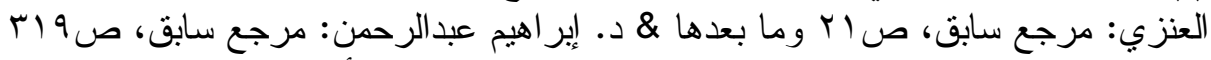

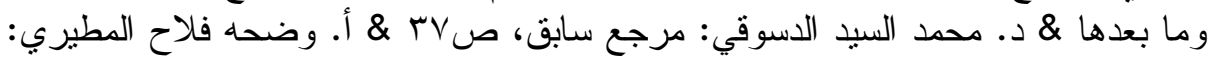
Philippe Rodier, op. cit., p. 101.

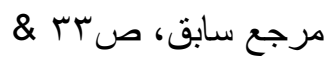

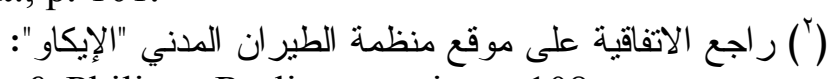

www.icao.int/meetings \& Philippe Rodier, op. cit., p. 108.

$\left({ }^{3}\right)$ Cass. Civ, 4 Février 2016, N14-29839 \& Cass. Civ, 11 Septembre 2014, N13-21459 \& Cass. Civ, 15 Janvier 2014, N12-12159, les sentences sur le site, www.legifrance.gouv.fr 
الطائرة بو اسطة السلطات العامة(') و وهو ما أثنارت إليه المـادة 26- L6131-

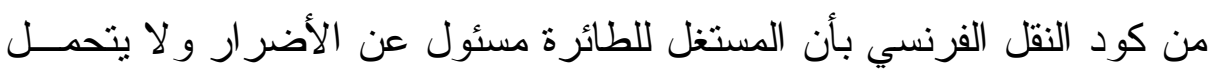

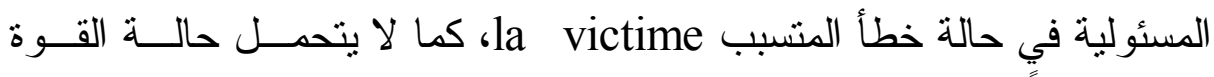
القاهرة طبقاً لما جاء بالمادة 26131-3 من كود النقل الفرنسي.

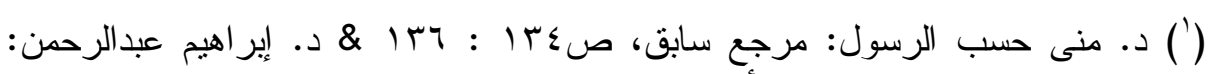

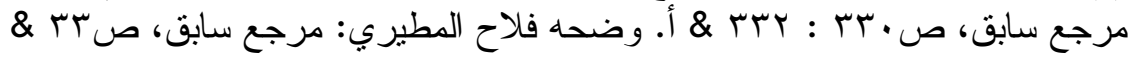
Thierry Mazoyer, op. cit., \& Aurélie Vaudry, la responsabilité civile des transporteurs aériens: une protection accure des passagers, le 23 Aôut 2015, sur le site, www.avocats-picovschi.com/la-responsabilite \& Michèle Bauer, Crash aérien: Quelles sont les responsabilités á engager, le 30 Juillet 2014, sur le site, www.village-justice.com 


\section{الخاتمة}

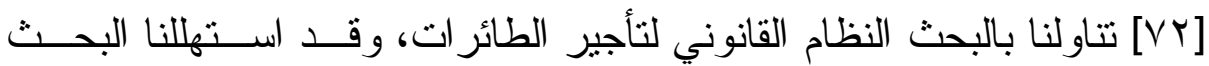

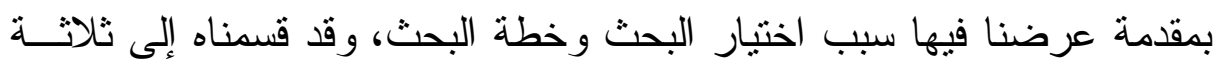

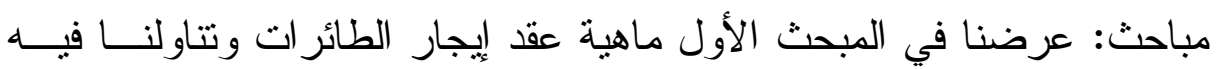
تعريف عقد الإيجار وخصائصه وطبيعته القانونية وقلنا أنه عقد إيجار أثنــياء

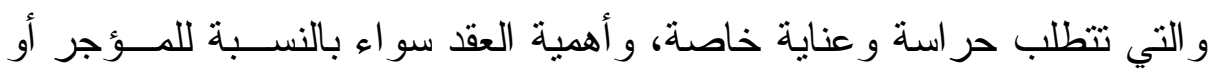

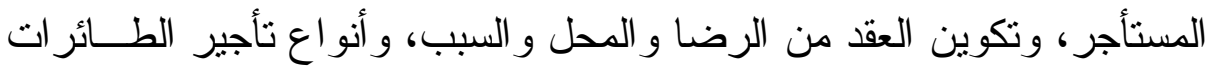

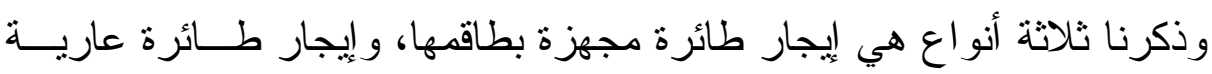
بدون طاقمها، ونظام التأجير التمويلي للطائر ات.

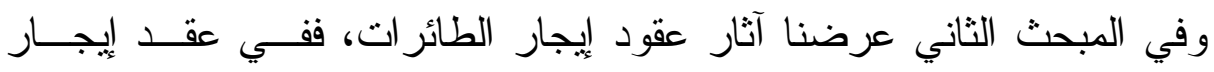
الطائرة مجززة يرتب التزامات على المؤجر بنقل المسافرين و أمتعــتهم و إدارة

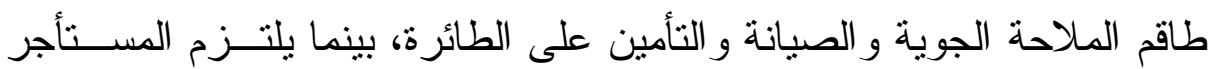

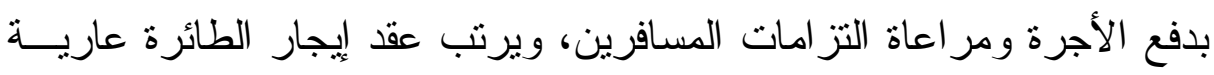

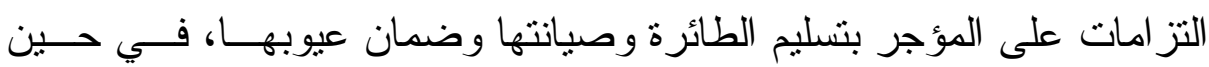

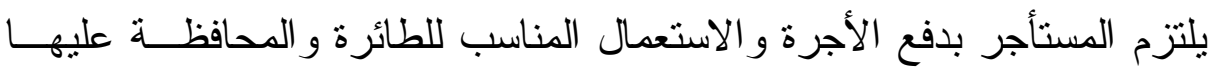

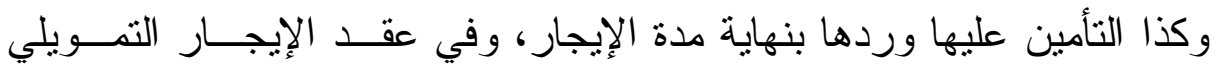

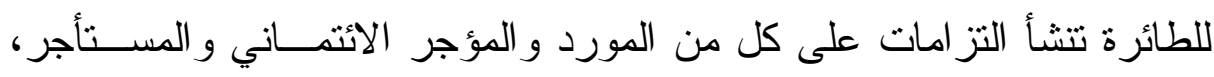

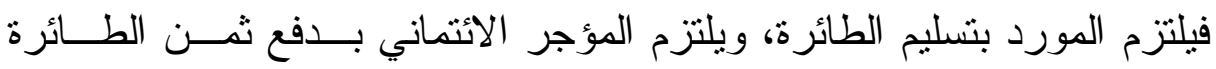

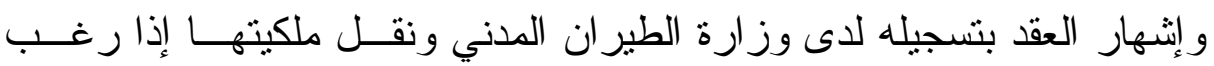

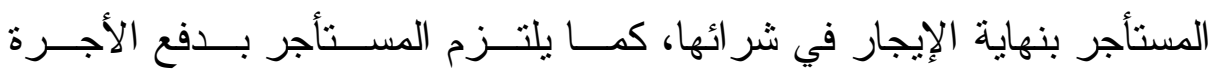

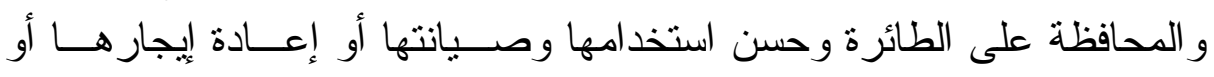

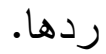

وفي المبحث الثالث تتاولنا المسئولية عن أضر ار الطائر ات المستأجرة، والتـي

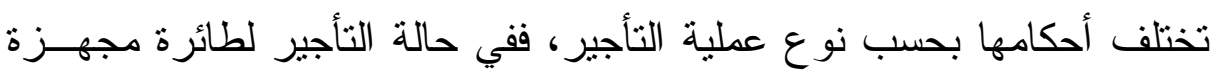

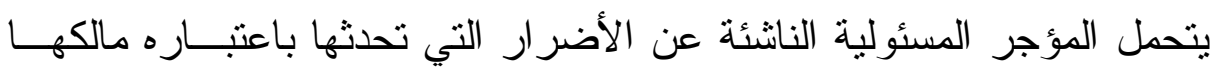

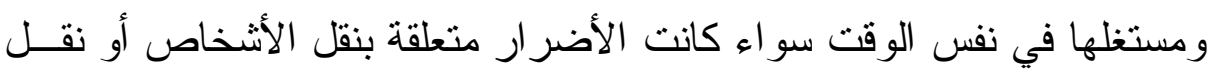

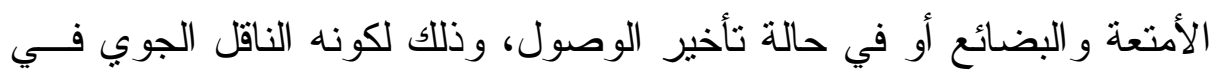

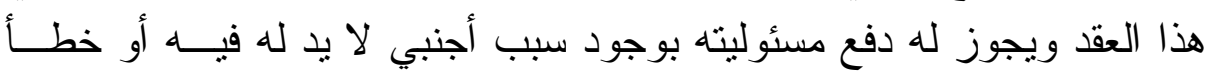


المضرور أو وجود نزاع مسلح أو اضطر ابات، أو منع استعمال الطائرة مــن

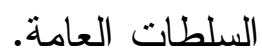

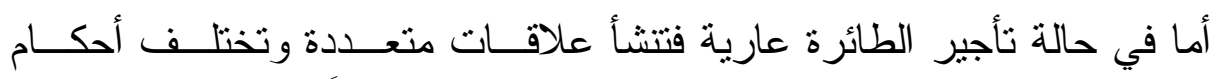

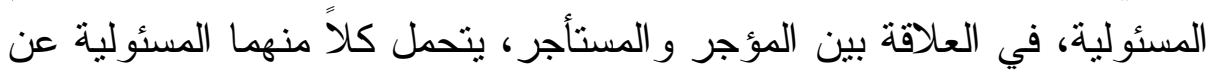

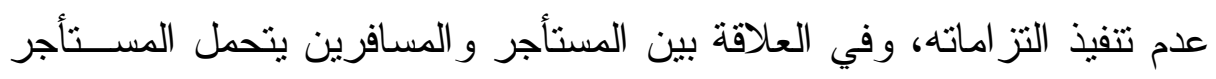

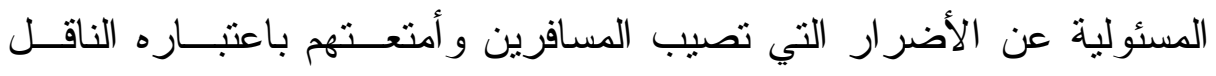

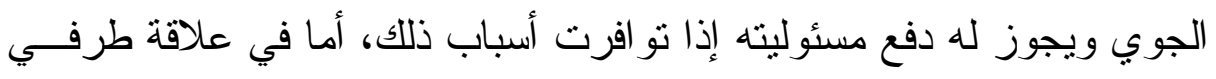

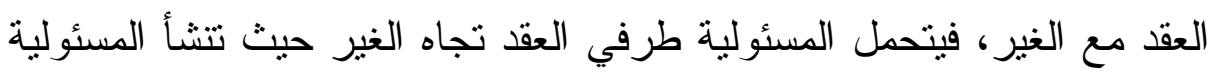

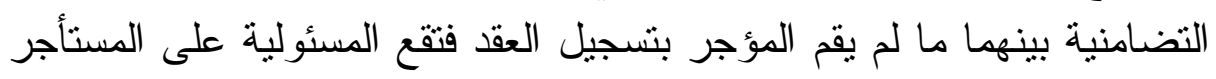

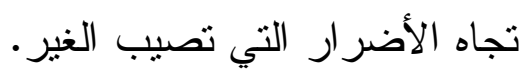

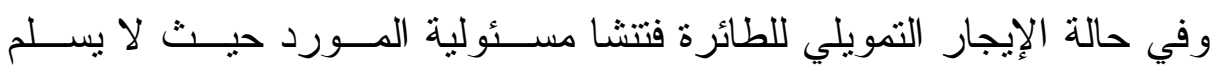

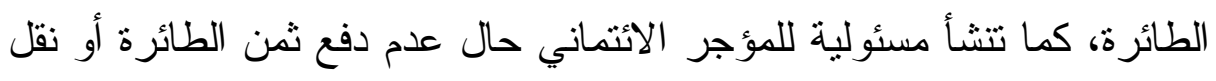

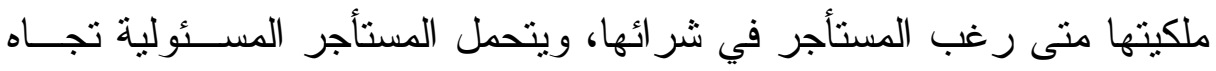

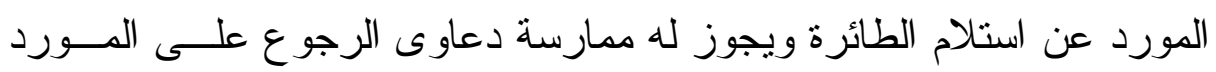

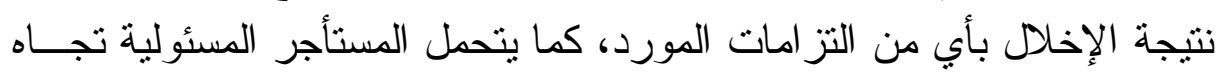

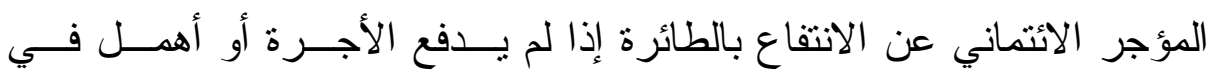
المحافظة على الطائرة ولم يقم بصيانتها.

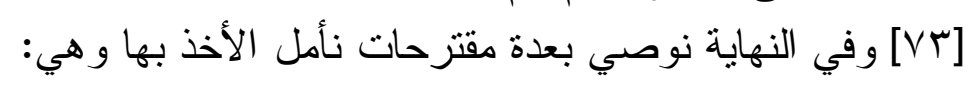

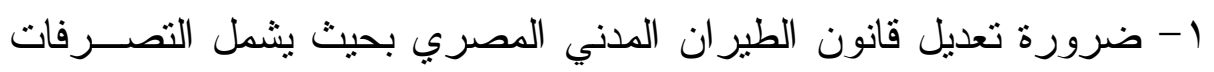

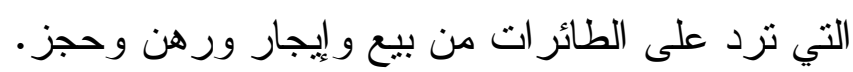

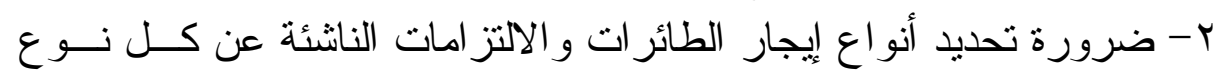

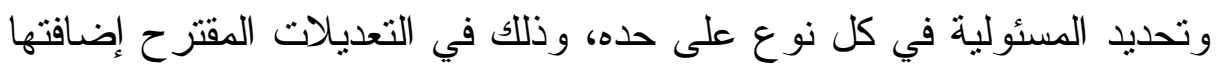
لقانون الطير ان المدني المصري.

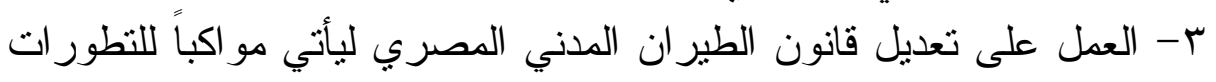

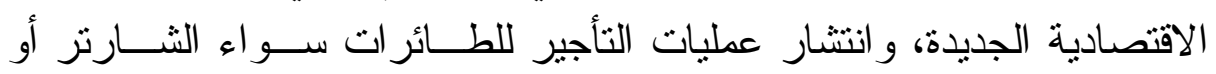

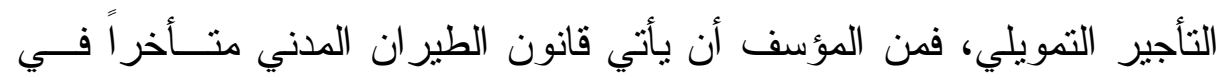
التنظيم القانوني لتأجير الطائرات عن التثريعات الممانكة العربية والأجنبية. 
ع - نأمل في التعديلات القانونية على قانون الطبر ان المــدني الأخــذ بعـين

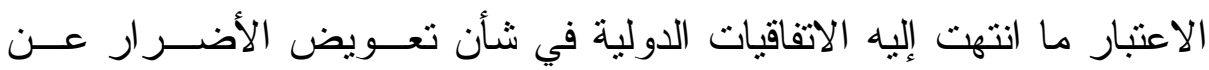
حو ادث الطائر ات خاصة ما جاء باتفاقية مونتريال . 1999

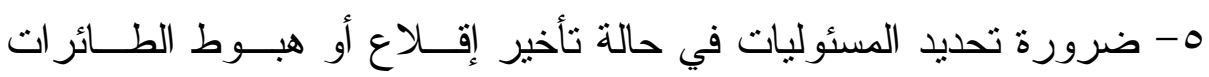

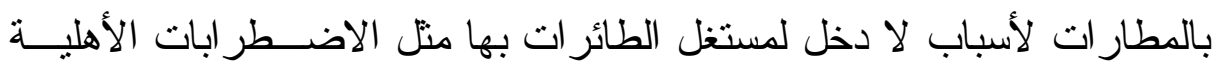
و النز اعات المسلحة، وأخطاء الطيارين المهنية. 
